BNL-52202

(Rev. 12/95)

UC-700

RECEIVED

MAR O 71996

OSTI

\title{
U.S. STATUTES OF GENERAL INTEREST \\ TO SAFEGUARDS AND SECURITY OFFICERS
}

\author{
J.J. Cadwell \\ C.J. Ruger
}

December 1995

\author{
Engineering Technology Division \\ Department of Advanced Technology \\ Brookhaven National Laboratory \\ Upton, New York
}

Under the U.S. Department of Energy Contract DE-AC02-76CH00016 

BNL-52202

(Rev. 12/95)

UC-700

\title{
U.S. STATUTES OF GENERAL INTEREST TO SAFEGUARDS AND SECURITY OFFICERS
}

\author{
J.J. Cadwell \\ C.J. Ruger
}

December 1995

Engineering Technology Division

Department of Advanced Technology

Brookhaven National Laboratory

Upton, New York

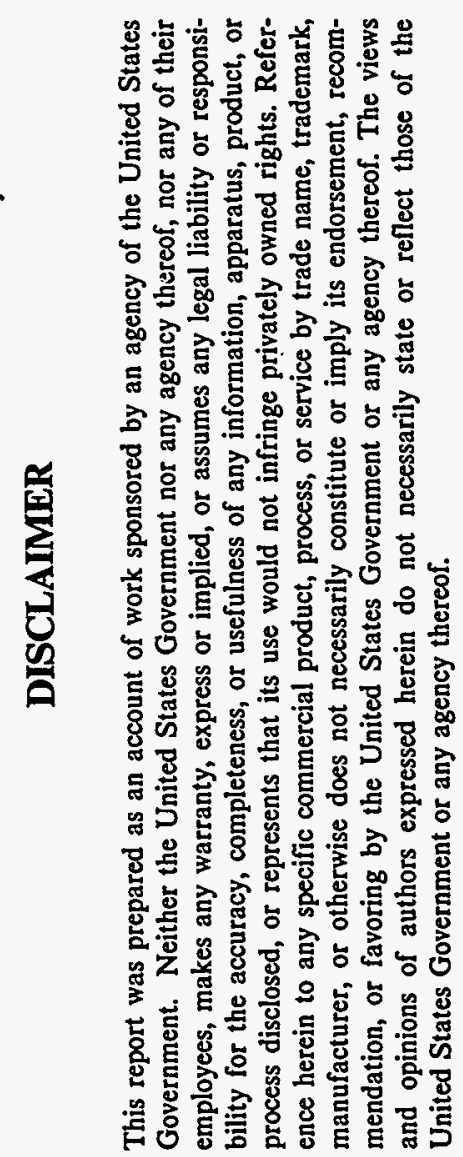

Under the U.S. Department of Energy Contract DE-AC02-76CH00016 
DISCLAIMER

This report wes prepared as an account of work sponsored by an agency of the United States Government. Neither the Unitod States Governmeat nor any agency thereof, nor any of their employces, or any of their contractors, whbontractorn, or their employees, makes any warrantec, expressed or impliod, or assumes any legal liabilities or responsibility for the accuracy, completeness, or usefulness of an information, sparatus, product, or process dieclosed, or represents that its use would not infringe privately owned rights. Reference bereia to any spocific commercial product, process or service by trade name, trademark, menufacturer, or otherwise, does not necessarily constitute or imply its endorsement, recommendation, or favoring by the Uaited States Governmeat or any ageacy, contractor, or wubcontractor thereof. The views and opinions of authors expressed herein do not necessarily state or reflect those of the Unitod States Government or any agency, contractor or subcontractor thereof. 


\section{PREFACE}

This document is one of a three volume set. BNL 52201 is titled, "Selected Text of Atomic Energy Act, Executive Orders and Other Laws of General Interest to Safeguards and Security Executives", and contains detailed information for use by executives. BNL 52202 is titled, "U.S. Statutes of General Interest to Safeguards and Security Officers", and contains less detail than BNL 52201. It is intended for use by officers. BNL 52203 is titled, "U.S. Statutes for Enforcement by Security Inspectors", and only contains statutes to be applied by uniformed security inspectors.

These volumes are a newly updated version of a set of documents of similar titles published in September 1988, which were an updated version of an original set of documents published in November 1983. The first two versions were prepared by Jerry J. Cadwell, Esq. The current version was prepared by Jerry J. Cadwell, Esq. and Charles J. Ruger, both of the Engineering Technology Division, Brookhaven National Laboratory, Upton, New York. They both wish to express their thanks to Jeanne Madaia, Ann Fort and Janice DePass for their invaluable assistance in the final preparation of these documents. 


\section{CONTENTS}

Page

I. Indexes

A. Index by Topic for Volumes 1 and $2 \ldots \ldots \ldots \ldots$

xi

B. Index Selected Portions of Title 18 of the Laws of the United

xxxiii

11. Title 42. United States Code (Atomic Energy Act of 1954 as Amended)

- Selected Enforcement Provisions

Section

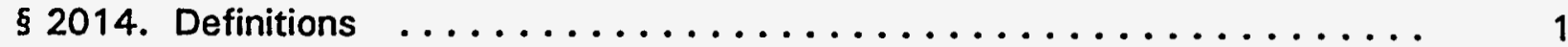

$\S 2077$. Prohibition $\ldots \ldots \ldots \ldots \ldots \ldots \ldots \ldots \ldots \ldots \ldots \ldots \ldots \ldots$

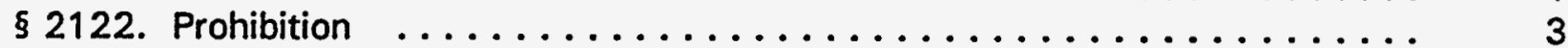

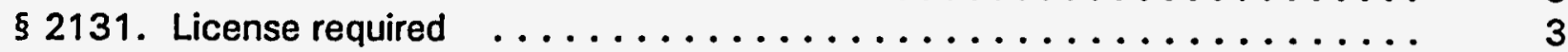

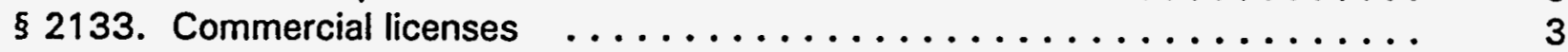

§ 2134. Medical therapy and research and development $\ldots \ldots \ldots \ldots \ldots \ldots$

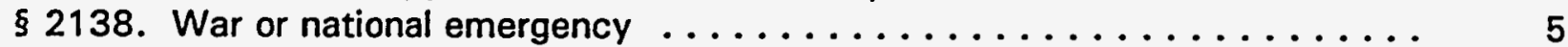

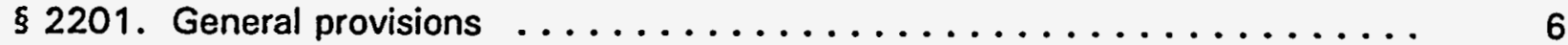

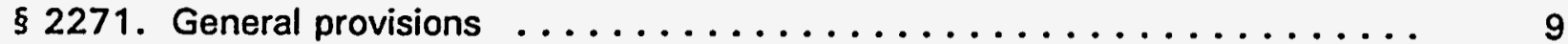

§ 2272. Violation of specific sections $\ldots \ldots \ldots \ldots \ldots \ldots \ldots \ldots \ldots \ldots \ldots$

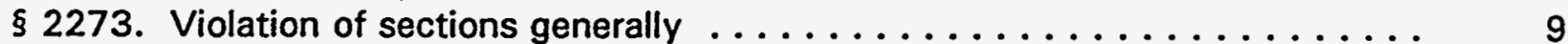

$\S 2274$. Communication of Restricted Data $\ldots \ldots \ldots \ldots \ldots \ldots \ldots$

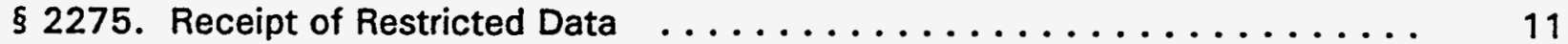

$\S 2276$. Tampering with Restricted Data $\ldots \ldots \ldots \ldots \ldots \ldots \ldots$

$\S 2277$. Disclosure of Restricted Data $\ldots \ldots \ldots \ldots \ldots \ldots \ldots \ldots \ldots$

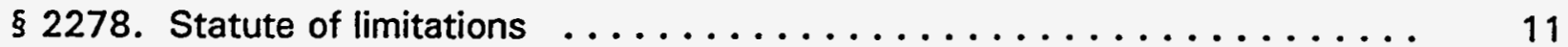

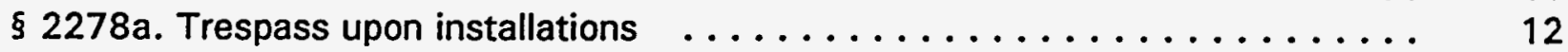

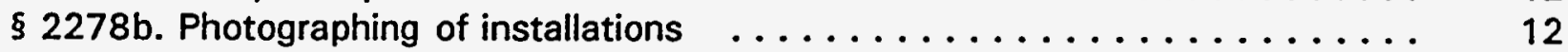

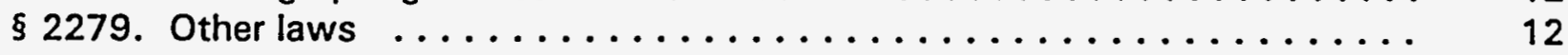

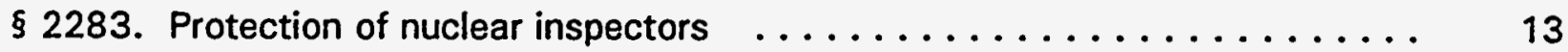

$\S 2284$. Sabotage of nuclear facilities or fuel $\ldots \ldots \ldots \ldots \ldots$

III. Title 18. Crimes and Criminal Procedure - United States Code . . . . . . . 15

A. ESPIONAGE AND CENSORSHIP $\ldots \ldots \ldots \ldots \ldots \ldots \ldots \ldots \ldots \ldots$

\section{Section}

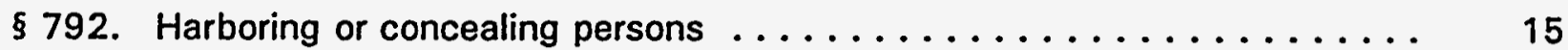

$\S 793$. Gathering, transmitting, or losing defense information . . . . . . . . . 15

$\S 794$. Gathering or delivering defense information to aid foreign government .. 17

$\S 795$. Photographing and sketching defense installations . . . . . . . . . . 18

$\S 796$. Use of aircraft for photographing defense installations . . . . . . . . 19 


\section{CONTENTS (Cont'd)}

Page

$\S 797$. Publication and sale of photographs of defense installations $\ldots \ldots \ldots$

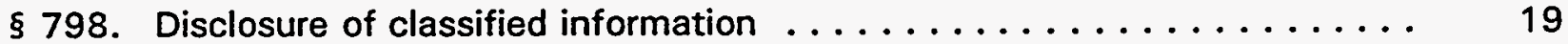

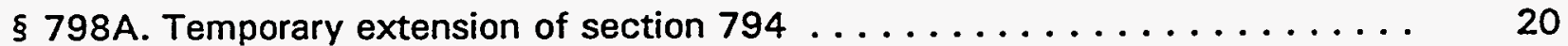

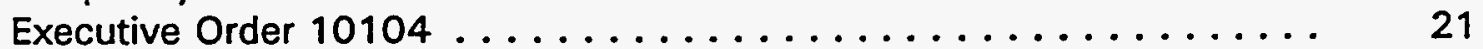

§ 1924. Unauthorized removal and retention of classified documents or material . 23

B. SABOTAGE .......................... 23

Section

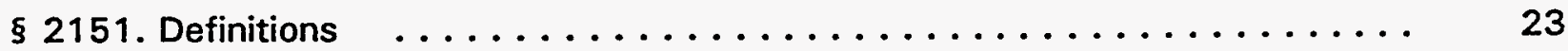

§ 2152. Fortifications, harbor defenses, or defensive sea areas . . . . . . . . . 24

$\S$ 2153. Destruction of war material, war premises, or war utilities . . . . . . 25

$\S 2154$. Production of defective war material, war premises, or war utilities . . . 25

$\S 2155$. Destruction of national-defense materials, national-defense premises or national-defense utilities ..................... 25

$\S 2156$. Production of defective national-defense material, national-defense

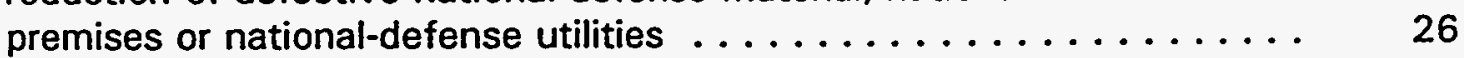

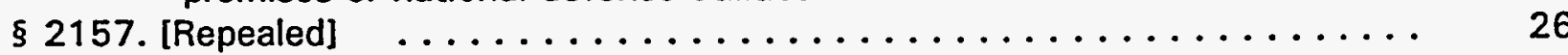

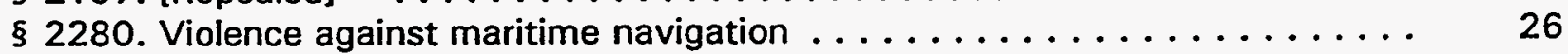

§ 33. Destruction of motor vehicles or motor vehicle facilities . . . . . . . . 29

C. TREASON AND SUBVERSIVE ACTIVITIES $\ldots \ldots \ldots \ldots \ldots \ldots$

Section

$\S 2381$. Treason $\quad \ldots \ldots \ldots \ldots \ldots \ldots \ldots \ldots \ldots \ldots \ldots \ldots \ldots$

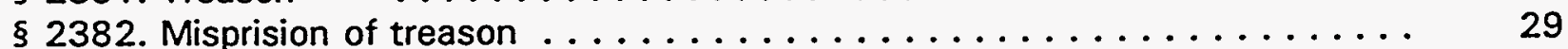

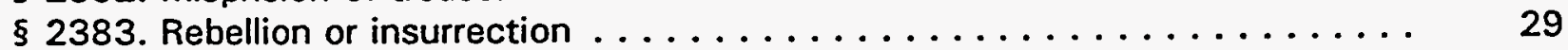

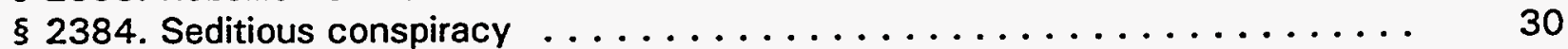

$\S 2385$. Advocating overthrow of Government ................ 30

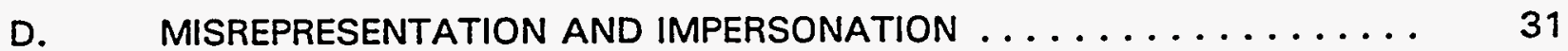

Section

$\S 499$. Military, naval, or official passes . . . . . . . . . . . . . . 31

$\S$ 701. Official badges, identification cards, other insignia . . . . . . . . 31

§ 872. Extortion by officers or employees of the United States . . . . . . . . 31

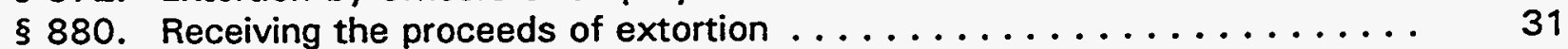

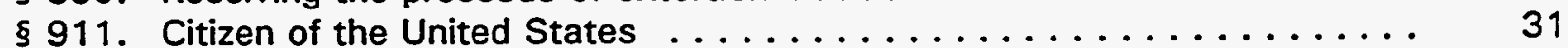

§ 912. Officer or employee of the United States ................. 32

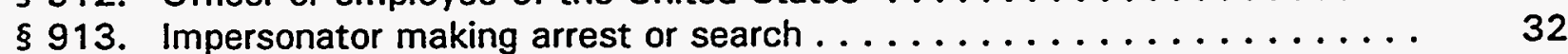

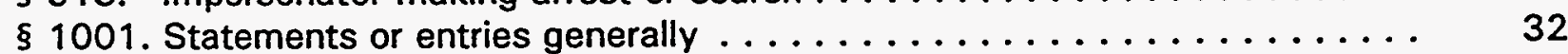

$\S 1031$. Major fraud against the United States . . . . . . . . . . . . . . 32 
$\S 1516$. Obstruction of Federal audit $\ldots \ldots \ldots \ldots \ldots \ldots \ldots \ldots \ldots \ldots$

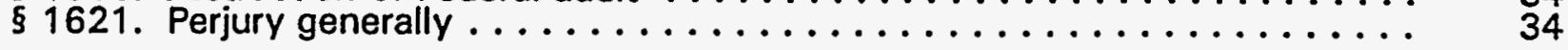

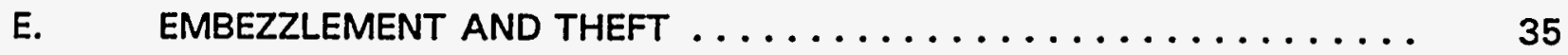

Section

$\S 21$. Stolen or counterfeit nature of property for certain crimes defined . . . . 35

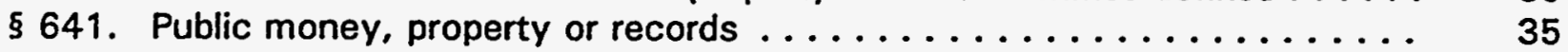

$\S 643$. Accounting generally for public money . . . . . . . . . . . . . . 36

\$659. Interstate or foreign shipments by carrier; State prosecutions . . . . . 36

\$ 831. Prohibited transactions involving nuclear materials ... . . . . . . . 37

$\S 2111$. Special maritime and territorial jurisdiction . . . . . . . . . . . . . . 41

$\S 2112$. Personal property of United States . . . . . . . . . . . . . . . . . . 41

$\S 2114$. Mail, money, or other property of United States . . . . . . . . . . . . 41

\$ 2117 . Breaking or entering carrier facilities . . . . . . . . . . . . . 41

§ 2119. Motor vehicles . . . . . . . . . . . . . . . . . . . . . . . 42

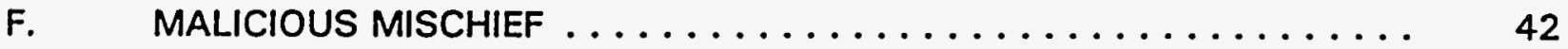

Section

$\S 1361$. Government property or contracts .................. 42

$\S 1362$. Communication lines, stations or systems . . . . . . . . . . . 42

$\S 1363$. Buildings or property within special maritime and territorial jurisdiction .. 43

G. CONSPIRACY ........................ 43

\section{Section}

§ 371. Conspiracy to commit offense or to defraud United States . . . . . . . 43

H. SEARCHES AND SEIZURES $\ldots \ldots \ldots \ldots \ldots \ldots \ldots \ldots$

Section

\$ 111. Assaulting, resisting, or impeding certain officers or employees $\ldots \ldots$. . 43

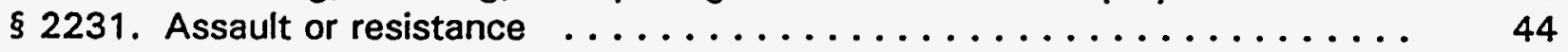

$\S 2232$. Destruction or removal of property to prevent seizure . . . . . . . . . . 44

\$ 2233. Rescue of seized property . . . . . . . . . . . . . . . . . . . 45

$\S 2234$. Authority exceeded in executing warrant . . . . . . . . . . . . . 45

\$ 2235. Search warrant procured maliciously . . . . . . . . . . . . . . . 45

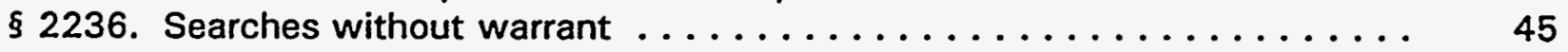

\$ 3118. Implied consent for certain tests ................... 45

\$3125. Emergency pen register and trap and trace device installation . . . . . . 46 


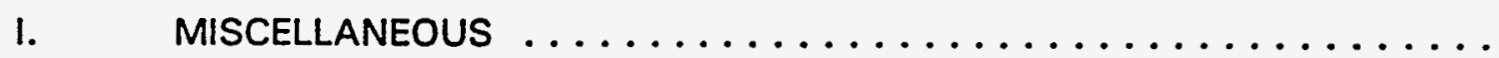

Section

$\S 175$. Prohibitions with respect to biological weapons . . . . . . . . . . .

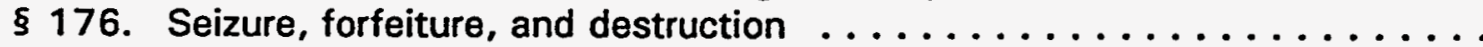

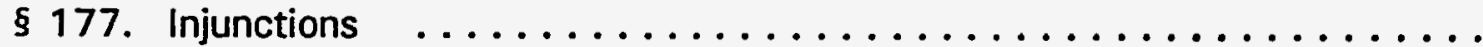

$\S 178$. Definitions (Biological weapons) $\ldots \ldots \ldots \ldots \ldots \ldots \ldots \ldots \ldots \ldots$

$\S 231$. Civil disorders .............................

$\S 841$. Definitions (Explosives) $\ldots \ldots \ldots \ldots \ldots \ldots \ldots \ldots \ldots \ldots \ldots \ldots \ldots$

50

$\S 844$. Penalties (Use of explosives or fire) $\ldots \ldots \ldots \ldots \ldots \ldots \ldots \ldots \ldots \ldots$

§ 873. Blackmail . . . . . . . . . . . . . . . . . . . . . . . . . 54

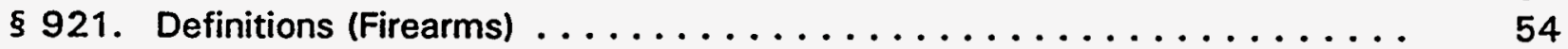

$\S 927$. Effect on State law (Firearms) . . . . . . . . . . . . . . . . . . 62

$\S 930$. Possession of firearms and dangerous weapons in Federal facilities . . . . 62

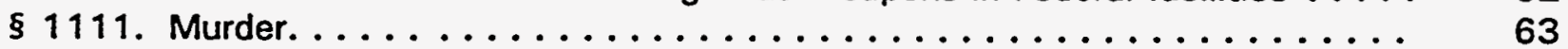

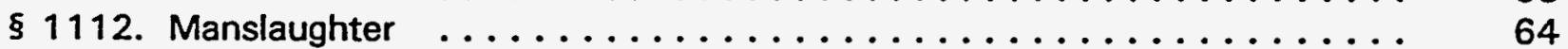

$\S 1121$. Killing persons aiding Federal investigations or State correctional officers 64

§ 1382. Entering military, naval, or Coast Guard property . . . . . . . . . . 65

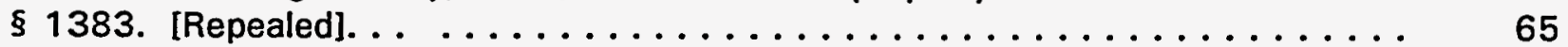

$\S 1864$. Hazardous or injurious devices on Federal lands . . . . . . . . . . 65

$\S 2071$. Concealment, removal, or mutilation generally . . . . . . . . . . . . 67

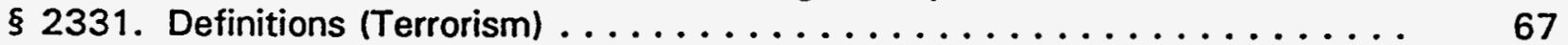

$\S 2332$. Use of weapons of mass destruction $\ldots \ldots \ldots \ldots \ldots \ldots$

$\S 2338$. Exclusive Federal jurisdiction . . . . . . . . . . . . . . . . . 69

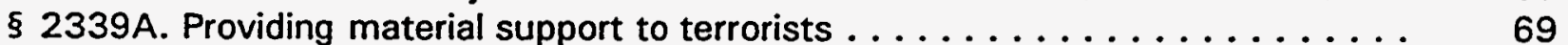

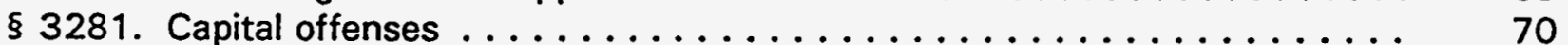

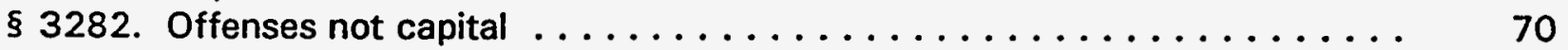

$\S 3286$. Extension of statute of limitation for certain terrorism offenses . . . . . 70

J. $\quad$ ARSON ............................. 70

Section

§ 7. Special maritime and territorial jurisdiction of the United States defined . 70

§ 81. Arson within special maritime and territorial jurisdiction . . . . . . . 71 


\section{CONTENTS (Cont'd)}

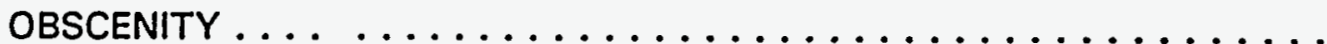

Section

$\$ 1460$. Possession with intent to sell, and sale, of obscene matter on Federal

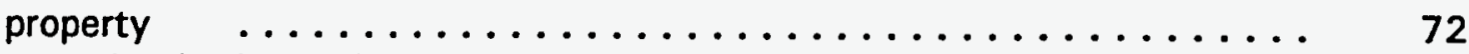

\$ 1466. Engaging in the business of selling or transferring obscene matter .... 72

$\$ 1467$. Criminal forfeiture . . . . . . . . . . . . . . . . . . . 72

IV. TITLE 50. INTERNAL SECURITY ACT OF THE UNITED STATES CODE . . . 79

Section

\$47a. Information concerning illegal introduction, manufacture, acquisition or export of special nuclear material or atomic weapons or conspiracies relating thereto; reward .........

$\$ 421$. Protection of identities of certain United States undercover intelligence officers, agents, informants, and sources ........... 79

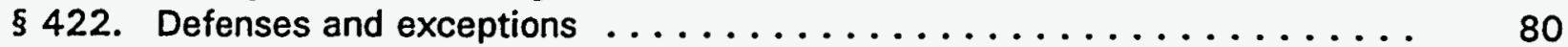

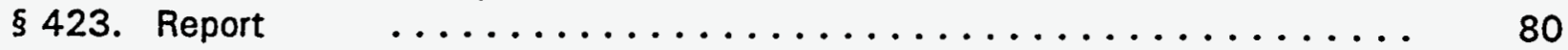

\$ 424. Extraterritorial jurisdiction $\ldots \ldots \ldots \ldots \ldots \ldots \ldots \ldots \ldots \ldots \ldots$

$\S 425$. Providing information to Congress $\ldots \ldots \ldots \ldots \ldots \ldots \ldots \ldots$

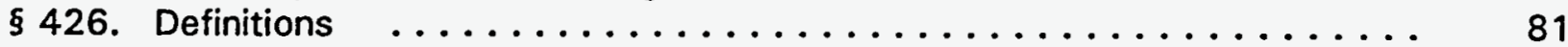

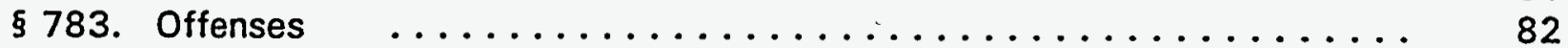

\$784. [Repealed] $\ldots \ldots \ldots \ldots \ldots \ldots \ldots \ldots \ldots \ldots \ldots \ldots \ldots \ldots$

$\S 797$. Security regulations and orders; penalty for violation $\ldots \ldots \ldots . \ldots 3$

V. TITLE 41 -- CODE OF FEDERAL REGULATIONS, CHAPTER 101, FEDERAL PROPERTY MANAGEMENT REGULATIONS (SELECTED PARTS ONLY) . .

Section

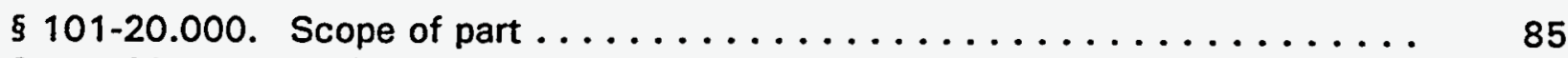

$\S 101-20.002$. Basic policy ........................... 85

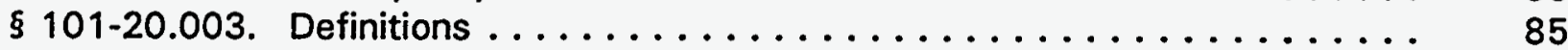

\$ 101-20.103. PHYSICAL PROTECTION AND BUILDING SECURITY $\ldots \ldots \ldots$

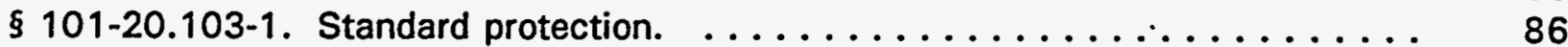

$\S 101-20.103-2$. Special protection ..................... 86

$\S 101-20.103-3$. Responsibilities of occupant agencies . . . . . . . . . . . . 87

$\S 101-20.3$. CONDUCT ON FEDERAL PROPERTY $\ldots \ldots \ldots \ldots \ldots \ldots \ldots \ldots$

$\S 101-20.300$. Applicability . . . . . . . . . . . . . . . . . . 87 
$\S 101-20.301$. Inspection . . . . . . . . . . . . . . . .

$\S 101-20.302$. Admission to property . . . . . . . . . . . . . . .

$\S 101-20.303$. Preservation of property . . . . . . . . . . . . . .

88

$\S 101-20.304$. Conformity with signs and directions $\ldots \ldots \ldots \ldots \ldots \ldots$

88

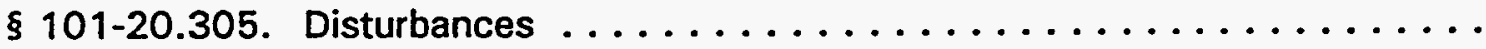

88

§ 101-20.306. Gambling

88

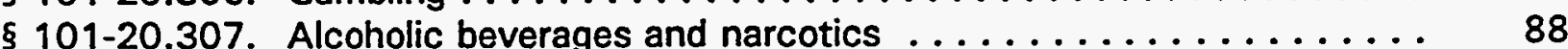

$\S 101-20.308$. Soliciting, vending, and debt collection . . . . . . . . . . . 89

$\S 101-20.309$. Posting and distributing materials . . . . . . . . . . . . . 89

$\S$ 101-20.310. Photographs for news, advertising, or commercial

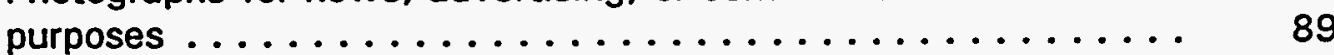

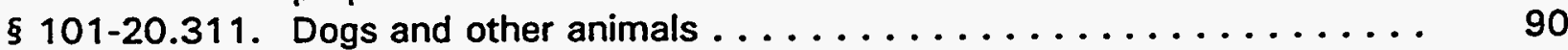

$\S 101-20.312$. Vehicular and pedestrian traffic . . . . . . . . . . . . . 90

$\S 101-20.313$. Explosives .......................... 90

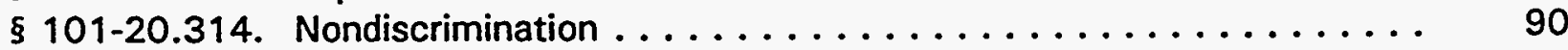

$\S 101-20.315$. Penalties and other laws . . . . . . . . . . . . . . . 90 


\section{INDEXES}

A. INDEX BY TOPIC FOR VOLUMES 1 AND 2

Citation ${ }^{*} \quad$ Vol. ${ }^{*} \quad$ Page

Agency of United States

Definition of

Agreement for Cooperation

Definition of

Aircraft used for Photographing or Sketching

Applicability of Other Laws

Arrest Authority

Attorney General

False Representations

Arson

Assault

Criminal
Sec. 11

42 U.S.C. § 2014(a)

Sec. 11

42 U.S.C. \& 2014(b)

Sec. 230

18 U.S.C.

42 U.S.C. § $2278 b$

Sec. 231

42 U.S.C. § 2279

Sec. $161(k)$

42 U.S.C. § 2201 (k)

Sec. $221(c)$

42 U.S.C. § 2271 (c)

18 U.S.C. § 913

18 U.S.C. § $81,841,844$

2

V-59,38,39

$71,50,51$

18 U.S.C. § 2231
76

3

3

3

3

12

V-6,7

18,19

76

12

76

12

76

12

60

7

60

7

72

72

72

$\mathrm{V}-20$

32

-Sec. means a section of the Atomic Energy Act. Section means a section of this report.

"Volume 1 refers to this book. Volume 2 refers to a companion book entitled Selected Text of Atomic Energy Act, Executive Orders and Other Laws of General Interest to Safeguards and Security Executives. 


\section{A. INDEX BY TOPIC (Cont'd)}

\begin{tabular}{|c|c|c|c|}
\hline & Citation & Vol. & Page \\
\hline Mail Matters & 18 U.S.C. § 2114 & $\begin{array}{l}2 \\
1\end{array}$ & $\begin{array}{r}V-29 \\
41\end{array}$ \\
\hline Of Inspectors & Sec. $235(b)$ & $\begin{array}{l}2 \\
1\end{array}$ & $\begin{array}{l}80 \\
13\end{array}$ \\
\hline & 42 U.S.C. $\S 2283(b)$ & $\begin{array}{l}2 \\
1\end{array}$ & $\begin{array}{l}80 \\
13\end{array}$ \\
\hline Of Certain Officers & 18 U.S.C. $\S 111$ & $\begin{array}{l}2 \\
1\end{array}$ & $\begin{array}{r}V-31 \\
43\end{array}$ \\
\hline Of Employees & 18 U.S.C. $\S 111$ & $\begin{array}{l}2 \\
1\end{array}$ & $\begin{array}{r}V-31 \\
43\end{array}$ \\
\hline Atomic Energy, Definition of & $\begin{array}{l}\text { Sec. } 11(c) \\
42 \text { U.S.C. } \$ 2014(c)\end{array}$ & $\begin{array}{l}2 \\
1 \\
2 \\
1\end{array}$ & $\begin{array}{l}3 \\
1 \\
3 \\
1\end{array}$ \\
\hline Atomic Weapon, Definition of & $\begin{array}{l}\text { Sec. } 11(d) \\
42 \text { U.S.C. } \S 2014(d)\end{array}$ & $\begin{array}{l}2 \\
2\end{array}$ & $\begin{array}{l}3 \\
3\end{array}$ \\
\hline Atomic Weapons, Possession & $\begin{array}{l}\text { Sec. } 92 \\
42 \text { U.S.C. } \$ 2122\end{array}$ & $\begin{array}{l}2 \\
1 \\
2 \\
1\end{array}$ & $\begin{array}{r}25 \\
3 \\
25 \\
3\end{array}$ \\
\hline $\begin{array}{l}\text { Authority of Commission } \\
\text { Production of Atomic Weapons } \\
\text { Material for Dept. of Defense Use } \\
\text { Sale of Materials to Other Foreign Nations }\end{array}$ & $\begin{array}{l}\text { Sec. } 91 \\
42 \text { U.S.C. } \$ 2121 \\
42 \text { U.S.C. } \$ 2121(\mathrm{a}) \\
42 \text { U.S.C. } \$ 2121(\mathrm{~b}) \\
42 \text { U.S.C. } \$ 2121(\mathrm{c})\end{array}$ & $\begin{array}{l}2 \\
2 \\
2 \\
2 \\
2\end{array}$ & $\begin{array}{l}24 \\
24 \\
24 \\
24 \\
25\end{array}$ \\
\hline Badges and Passes, Counterfeiting of & $\begin{array}{l}\text { Sec. } 223 \\
18 \text { U.S.C. } \S 499,701 \\
42 \text { U.S.C. } \S 2273\end{array}$ & $\begin{array}{l}2 \\
1 \\
2 \\
1 \\
2 \\
1\end{array}$ & $\begin{array}{r}73 \\
9 \\
V-19 \\
31 \\
73 \\
9\end{array}$ \\
\hline $\begin{array}{l}\text { Biological Weapons } \\
\text { Definitions }\end{array}$ & 18 U.S.C. $§ 178$ & $\begin{array}{l}2 \\
1\end{array}$ & $\begin{array}{r}V-36 \\
48\end{array}$ \\
\hline Injunctions & 18 U.S.C. § 177 & $\begin{array}{l}2 \\
1\end{array}$ & $\begin{array}{r}V-36 \\
48\end{array}$ \\
\hline
\end{tabular}




\section{A. INDEX BY TOPIC (Cont'd)}

Seizure

Blackmail

Bodily Injury

With Stolen Motor Vehicle

Breaking and Entering

Carrier Facilities

By-product Material Def.

Domestic Possession

Foreign Dist.

Licensing and Distribution

Capital Offenses

Citizenship, False Representation of

Citizenship, Misrepresentation

Civil Disorders

Classified Information

Disclosure
Citation

18 U.S.C. § 175

18 U.S.C. § 176

Vol.

Page

18 U.S.C. § 872,873

$\begin{array}{lr}2 & V-19,42 \\ 1 & 31,54\end{array}$

Sec. 11 (q)

42 U.S.C. ₹ $2014(q)$

18 U.S.C. § 2119

2
2

2

1

18 U.S.C. § 2117

2

1

V-35

47

V-35

47

1

4

4

V-30

42

V-29

41

Sec. 11 (e)

42 U.S.C. § 2014(e)

42 U.S.C. § 2111

42 U.S.C. § 2112

Sec. 81 and 82

18 U.S.C. § 3281

V-58

2
1

70

18 U.S.C. § 911

V-19

1

31

18 U.S.C. § 911

V-19

31

18 U.S.C. § 231

2
1

V-37

49

Sec. 224, 225, 226, 227

18 U.S.C. § 798

74-75

10-11

V-7

19

42 U.S.C. § 2274

74 10 


\section{A. INDEX BY TOPIC (Cont'd)}

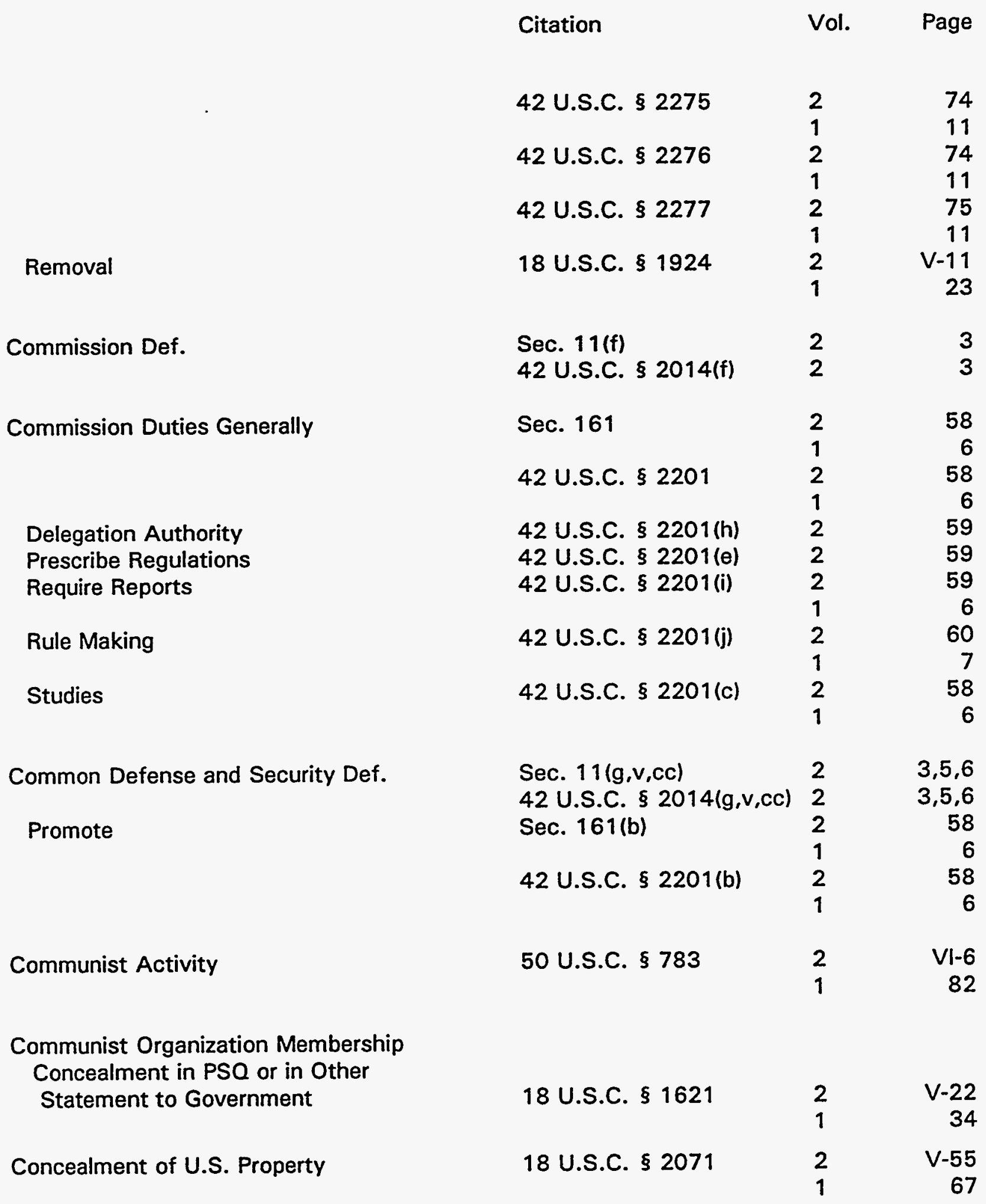




\section{A. INDEX BY TOPIC (Cont'd)}

Citation

Vol. Page

\section{Conspiracy \\ General}

Seditious

Conspiracy Generally

Establish Dictatorship

Seditions

Contempt Proceedings

Counterfeiting of Badges and Passes
18 U.S.C. § 371

18 U.S.C. § 2384

18 U.S.C. § 371

18 U.S.C. § 2156

50 U.S.C. § 783

18 U.S.C. § 2384

Sec. 233

42 U.S.C. § 2281

Sec. 11

42 U.S.C. § 2014

Sec. 223

42 U.S.C. § 2273

18 U.S.C. § 499,701

$\begin{array}{rr}2 & V-31 \\ 1 & 43\end{array}$

$2 \quad V-18$

130

$2 \quad V-31$

$1 \quad 43$

$2 \quad V-14$

$1 \quad 26$

2 VI-6

$1 \quad 82$

$2 \quad V-18$

130

276

$2 \quad 76$

23

23

273

$1 \quad 9$

273

19

$2 \quad V-19$

$1 \quad 31$

Dangerous Weapons, Materials, etc. Introduction of

Sec. 223

42 U.S.C. § 2273

18 U.S.C. § 176, 930

18 U.S.C. § 1864

18 U.S.C. § $2332 a$

Sec. 11 (h)

42 U.S.C. \& 2014(h)

$\begin{array}{rr}2 & 73 \\ 1 & 9 \\ 2 & 73 \\ 1 & 9 \\ 2 & V-35, V-50 \\ 1 & 47,62 \\ 2 & V-53 \\ 1 & 65 \\ 2 & V-56 \\ 1 & 68\end{array}$

2
3

3 


\section{A. INDEX BY TOPIC (Cont'd)}

\begin{tabular}{|c|c|c|c|}
\hline & Citation & Vol. & Page \\
\hline Gathering or Transmitting & 18 U.S.C. $\$ 793$ & $\begin{array}{l}2 \\
1\end{array}$ & $\begin{array}{r}V-3 \\
15\end{array}$ \\
\hline Disclosure & 18 U.S.C. § 794 & $\begin{array}{l}2 \\
1\end{array}$ & $\begin{array}{r}V-5 \\
17\end{array}$ \\
\hline Removal & 18 U.S.C. § 1924 & $\begin{array}{l}2 \\
1\end{array}$ & $\begin{array}{r}V-11 \\
23\end{array}$ \\
\hline Design, Definition of & $\begin{array}{l}\text { Sec. } 11(i) \\
42 \text { U.S.C. § } 2014(i)\end{array}$ & $\begin{array}{l}2 \\
1 \\
2 \\
1\end{array}$ & $\begin{array}{l}3 \\
1 \\
3 \\
1\end{array}$ \\
\hline Destruction of U.S. Property & 18 U.S.C. § 2232 & $\begin{array}{l}2 \\
1\end{array}$ & $\begin{array}{r}V-32 \\
44\end{array}$ \\
\hline Destruction of War Material & 18 U.S.C. § 2155 & $\begin{array}{l}2 \\
1\end{array}$ & $\begin{array}{r}V-13 \\
25\end{array}$ \\
\hline Malicious Mischief & $\begin{array}{l}18 \text { U.S.C. \& } 1361 \\
1362,1363\end{array}$ & $\begin{array}{l}2 \\
1\end{array}$ & $\begin{array}{r}V-30, V-31 \\
42,43\end{array}$ \\
\hline Production of War Material & 18 U.S.C. § 2154 & $\begin{array}{l}2 \\
1\end{array}$ & $\begin{array}{r}V-13 \\
25\end{array}$ \\
\hline Removal & 18 U.S.C. § 2231 & $\begin{array}{l}2 \\
1\end{array}$ & $\begin{array}{r}V-32 \\
44\end{array}$ \\
\hline $\begin{array}{l}\text { Sabotage (Covers Government and } \\
\text { War Material) }\end{array}$ & Sec. 236 & $\begin{array}{l}2 \\
1\end{array}$ & $\begin{array}{l}80 \\
13\end{array}$ \\
\hline & 42 U.S.C. § 2284 & $\begin{array}{l}2 \\
1\end{array}$ & $\begin{array}{l}80 \\
13\end{array}$ \\
\hline & 18 U.S.C. § $2151-2156$ & $\begin{array}{l}2 \\
1\end{array}$ & $\begin{array}{r}V-11-14 \\
23-26\end{array}$ \\
\hline Destruction of Motor Vehicles & 18 U.S.C. § 33 & $\begin{array}{l}2 \\
1\end{array}$ & $\begin{array}{r}V-17 \\
29\end{array}$ \\
\hline Disorders, Civil & 18 U.S.C. § 231 & $\begin{array}{l}2 \\
1\end{array}$ & $\begin{array}{r}V-37 \\
49\end{array}$ \\
\hline Embezzlement & $\begin{array}{l}\text { Appendix VE } \\
\text { Section IIIE } \\
18 \text { U.S.C. \$ } 641\end{array}$ & $\begin{array}{l}2 \\
1 \\
2 \\
1\end{array}$ & $\begin{array}{r}V-23 \\
35 \\
V-23 \\
35\end{array}$ \\
\hline
\end{tabular}




\section{A. INDEX BY TOPIC (Cont'd)}

Citation

Vol. Page

Accounting for Public Money

18 U.S.C. $§ 643$

V-24

18 U.S.C. § 659

36

Vehicle etc.

2

V-24

136

Espionage

Appendix V A

Section III A

V-3

1

15

Explosives

18 U.S.C. $\S 841,844$

V-38,39

18 U.S.C. § 33

50,51

$\mathrm{V}-17$

Motor Vehicles, Destruction of

18 U.S.C. $\$ 872$

$\mathrm{V}-19$

Extortion by Employee, etc. of Government

18 U.S.C. $\S 880$

31

Receiving Proceeds

18 U.S.C. $\S 880$

$\mathrm{V}-19$

2

1

31

Extortion by U.S. Officers

18 U.S.C. § 872

V-19

18 U.S.C. $\S 873$

31

V-42

Blackmail

1

2

54

Extraordinary Nuclear Occurrence Def.

Sec. $11(\mathrm{j})$

42 U.S.C. § $2014(\mathrm{j})$

18 U.S.C. § $831(\mathrm{e})(2)$

3

3
$V-27$

$V-27$

39

False Statements or Falsification Citizenship

18 U.S.C. $\S 911$

$\mathrm{V}-19$

Impersonation

Sec. 223

31

73

42 U.S.C. $§ 2273$

73

$\begin{array}{lll} & 1 & 9\end{array}$

18 U.S.C. $\S 912,913 \quad 2 \quad$ V-20

18 U.S.C. § 1621

32

Perjury

18 U.S.C. § 1001

$\mathrm{V}-22$

2

34

Statement to Government Generally

$\mathrm{V}-20$

2
1

32 


\section{A. INDEX BY TOPIC (Cont'd)}

Federal Bureau of Investigation

Financial Protection Def.

Firearms Carrying

Firearms Definition

Fire

Fissionable Material

Forgery of Badges and Passes

Forgery

Concealment

Passes
Citation

Sec. 221 (b)

42 U.S.C. § 2271 (b)

Sec. 11 (k)

42 U.S.C. § 2014(k)

Sec. $161(k)$

42 U.S.C. § 2201 (k)

18 U.S.C. § 930

18 U.S.C. § 921

18 U.S.C. \$ 841,844

Vol.

Page

2

1

2

1

2
2

2

1

2

1

2

1

See "Special Nuclear Material"

Sec. 223

42 U.S.C. § 2273

18 U.S.C. § 499,701

18 U.S.C. § 499

18 U.S.C. § 1001

Sec. 223

42 U.S.C. § 2273

18 U.S.C. § 1001
2
1

V-42

54

2
1

V-38, 39

50,51

72

9

72

\section{9}

4

4

60

7

60

V-50

62

2

2

1

2

1

2

1

73

9

73

9

V-19

31

V-19

31

V-20

32

73

9

73

9

V-20

32 


\section{A. INDEX BY TOPIC (Cont'd)}

For Title 18

For Title 42, Chap. 23

Fraud Against the Government

Government Agency, Definition of

Government Officer or Employee, etc.

Extortion by

Impersonation of

Obstruction of Auditor

Harboring Persons

Health and Safety

Homicide

Manslaughter

Murder
Citation

18 U.S.C. § 3282

Sec. 228

42 U.S.C. § 2278

18 U.S.C. § 1001

18 U.S.C. § 371

18 U.S.C. § 659

18 U.S.C. § 1031

18 U.S.C. § 1516

Sec. 11 (I)

42 U.S.C. § $2014($ (I)

Vol.

Page

V-58

70

75

11

75

11

V-20

32

V-31

43

V-24

36

V-20

32

V-22

34

2
2

4

4

18 U.S.C. § 872

V-19

31

18 U.S.C. § $912,913 \quad 2 \quad$ V-20

18 U.S.C. § 1516

32

$\mathrm{V}-22$

34

18 U.S.C. § 792

V-3

15

Sec. $11(v)$

42 U.S.C. \& 2014(v)

2

$\mathbf{5}$

18 U.S.C. § 1112

2
1

V-52

64

18 U.S.C. $\$ 1111$

V-51

63 


\section{A. INDEX BY TOPIC (Cont'd)}

Citation

Vol.

Page

Of Inspector

Sec. 235

2

79

42 U.S.C. § 2283(a)

13

79

Of Persons Aiding Investigations

18 U.S.C. \$ 1121

13

With Stolen Motor Vehicle

18 U.S.C. $\$ 2119$

V-52

64

V-30

42

Identities Protection of Agents

50 U.S.C. § 421

VI-3

Impersonator

Arrestor

18 U.S.C. § 913

$\checkmark-20$

Citizen

18 U.S.C. § 911

32

18 U.S.C. 8911

$\mathrm{V}-19$

Sec. 223

Officer of U.S.

42 U.S.C. § 2273

31

73

9

73

18 U.S.C. $\S 912,913$

9

$\mathrm{V}-20$

32

Indemnitor, Definition

Sec. $11(\mathrm{~m})$

42 U.S.C. § $2014(\mathrm{~m})$

2
2

4

4

Information Relating to the National Defense

Sec. 227

42 U.S.C. § 2277

18 U.S.C. § 793

75

11

75

11

V-3

15

Injunction Proceedings

Sec. 232

42 U.S.C. § 2280

76

18 U.S.C. $\$ 177$

76

V-36

Sec. 235

48

79

Inspectors Protection

42 U.S.C. § 2283 


\section{A. INDEX BY TOPIC (Cont'd)}

Citation

Vol. Page

Assault

Homicide

Insurrection

Intent of Congress

International Arrangement, Definition of

Interstate Shipment (Theft From)

Joint Committee Def.

Larceny (Generally)

Laws, Applicability of Other

Licensed Activity, Definition

Civil Penalties for Violations

Licensing Regulations

Fissionable Materials Production

Facilities

Source Materials
42 U.S.C. § 2283(b) 2

42 U.S.C. $\$ 2283(\mathrm{a})$

42 U.S.C. § 2283(a) 2

18 U.S.C. $\S 2381,23822$

2
1

V-17

29

Sec. 11

42 U.S.C. § 2014

2

Sec. $11(n)$

42 U.S.C. \& 2014(n)

2

18 U.S.C. § 659

18 U.S.C. § 2117

1

2

1

Sec. $11(0)$

42 U.S.C. § 2014(o)

2

18 U.S.C. § $21,641,6432$

$V-23, V-24$

1

35,36

Sec. 231

42 U.S.C. § 2279

2

76

12

76

12

Sec. $11(p)$

42 U.S.C. § 2014 (p)

Sec. 234

42 U.S.C. § 2282
4
4
77
77
4

$V-24$

$V-29$

41

4

4

6




\section{A. INDEX BY TOPIC (Cont'd)}

\begin{tabular}{|c|c|c|c|}
\hline & Citation & Vol. & Page \\
\hline Loss & $\begin{array}{l}\text { Sec. } 11(w) \\
42 \text { U.S.C. } \$ 2014(w)\end{array}$ & $\begin{array}{l}2 \\
2\end{array}$ & $\begin{array}{l}6 \\
6\end{array}$ \\
\hline Machine Guns & 18 U.S.C. $\S 921$ & $\begin{array}{l}2 \\
1\end{array}$ & $\begin{array}{r}V-42 \\
54\end{array}$ \\
\hline Mail & 18 U.S.C. § 2114 & $\begin{array}{l}2 \\
1\end{array}$ & $\begin{array}{r}V-29 \\
41\end{array}$ \\
\hline Malicious Mischief & $\begin{array}{l}18 \text { U.S.C. § } 1361,1362 \\
1363\end{array}$ & $\begin{array}{l}2 \\
1\end{array}$ & $\begin{array}{r}V-30,31 \\
42,43\end{array}$ \\
\hline \multicolumn{4}{|l|}{ Materials } \\
\hline $\begin{array}{l}\text { Source } \\
\text { Special Nuclear }\end{array}$ & $\begin{array}{l}\text { Sec. } 61-69 \\
42 \text { U.S.C. \$ } 2091-2099 \\
\text { Sec. } 51,53-58 \\
42 \text { U.S.C. \$ } 2071 \text {, } \\
2073-2078\end{array}$ & $\begin{array}{l}2 \\
2 \\
2 \\
2 \\
2\end{array}$ & $\begin{array}{r}19-22 \\
19-22 \\
11,11-19 \\
11 \\
11-19\end{array}$ \\
\hline Maritime Navigation (Violence Against) & 18 U.S.C. $§ 2280$ & $\begin{array}{l}2 \\
1\end{array}$ & $\begin{array}{r}V-14 \\
26\end{array}$ \\
\hline Misrepresentation of Citizenship & 18 U.S.C. § 911 & $\begin{array}{l}2 \\
1\end{array}$ & $\begin{array}{r}V-19 \\
31\end{array}$ \\
\hline \multicolumn{4}{|l|}{ Motor Vehicles } \\
\hline Destruction of & 18 U.S.C. $\$ 33$ & $\begin{array}{l}2 \\
1\end{array}$ & $\begin{array}{r}V-17 \\
29\end{array}$ \\
\hline Theft of & 18 U.S.C. § 2119 & $\begin{array}{l}2 \\
1\end{array}$ & $\begin{array}{r}V-30 \\
42\end{array}$ \\
\hline Mutilation of U.S. Property & 18 U.S.C. § 2071 & $\begin{array}{l}2 \\
1\end{array}$ & $\begin{array}{r}V-55 \\
67\end{array}$ \\
\hline National Defense Information & 18 U.S.C. $\S 793$ & $\begin{array}{l}2 \\
1\end{array}$ & $\begin{array}{r}V-3 \\
15\end{array}$ \\
\hline Nuclear Incident, Definition & $\begin{array}{l}\text { Sec. } 11(q, t) \\
42 \text { U.S.C. } \$ 2014(q, t)\end{array}$ & $\begin{array}{l}2 \\
2\end{array}$ & $\begin{array}{l}4,5 \\
4,5\end{array}$ \\
\hline
\end{tabular}




\section{A. INDEX BY TOPIC (Cont'd)}

Citation

Vol. Page

Obscene Matter
Criminal Forfeiture
Selling

Officer of U.S., False Representation of

Off-site, Definition

Operator, Definition

Overthrow of Government, Advocating

Passes (see Badges and Passes)

Forgery

Unlawful Possession

Passes and Badges, Counterfeiting of

Perjury

Person, Definition

Person Indemnified, Definition
18 U.S.C. $\S 1467 \quad 2 \quad$ V-60

18 U.S.C. $\S 1460,1467 \quad 2 \quad \begin{array}{r}1 \\ V-60\end{array}$

1

18 U.S.C. $\S 912$

V-20

$1 \quad 32$

Sec. 223

73

42 U.S.C. § 2273

2

18 U.S.C. 499,701

18 U.S.C. $\S 499,701 \quad 2$

Sec. 11 (j)

42 U.S.C. § 2014(j)

2
2

Sec. $11(r)$

42 U.S.C. § $2014(r)$

2
2

18 U.S.C. § 2385

$\begin{array}{lr}2 & V-18 \\ 1 & 30\end{array}$

18 U.S.C. § 499

2
1
2
1

V-19

18 U.S.C. § 701

V-19

31

18 U.S.C. § $499,701 \quad 2$

V-19

31

18 U.S.C. § 1621

2
1

V-22

34

Sec. 11 (s)

42 U.S.C. § 2014(s)

2
2

5

Sec. $11(t)$

42 U.S.C. § 2014(t)

2
2 


\section{A. INDEX BY TOPIC (Cont'd)}

Citation

Vol.

Page

Personnel Security Questionnaire (PSQ)

Falsification

18 U.S.C. § 1001

2

V-20

Photographing or Sketching

Commission Property

18 U.S.C. $\S 796,797$

V-7

19

Sec. 230

76

42 U.S.C. § $2278 b$

12

76

12

18 U.S.C. $\S 793(b)$

V-3

15

18 U.S.C. § 795

V-6

18

Produce, Definition

Sec. 11 (u)

42 U.S.C. § 2014(u)

5

5

Production Facility, Definition

Sec. $11(v)$

42 U.S.C. \& $2014(v)$

Sec. 101

5

License Required

42 U.S.C. § 2131

5

28

3

1

Sec. 236

28

Sabotage

42 U.S.C. § 2284

80 13 80 13

Protection of Identities of Agents

50 U.S.C. § 421

VI-3

1

79

Public Liability Def.

Sec. $11(w)$

42 U.S.C. § $2014(w)$

2

6

Sec. $11(j)$

42 U.S.C. § 2014(j)

2

$\begin{array}{llr}18 \text { U.S.C. \& } 659,2117 & 2 & \text { V-24,29 } \\ & 1 & 36,41\end{array}$

3

Radiation Off Site

Railroad Car Entered or Seal Broken 


\section{A. INDEX BY TOPIC (Cont'd)}

Citation

$\begin{aligned} & \text { Raw Source Material } \\ & \text { Definition }\end{aligned}$
Possession or Transfer, etc.
Rebellion
Insurrection
Receiving Stolen Goods
Records and Report - Concealment,
Removal or Mutilation
Refined Source Material
Definition
Possession or Transfer, etc.

Rescue Unlawful

Research and Development,

Definition

\section{Restricted Data}

Communication of

Disclosure of

$\begin{array}{llr}\text { Sec. 61-69 } & 2 & 19-22 \\ 42 \text { U.S.C. § 2091-2099 } & 2 & 19-22 \\ \text { Sec. 61-69 } & 2 & 19-22 \\ 42 \text { U.S.C. § } 2091-2099 & 2 & 19-22 \\ & & \\ 18 \text { U.S.C. § } 2383 & 2 & \text { V-17 } \\ & 1 & 29 \\ \text { 18 U.S.C. § } 2383 & 2 & \text { V-17 } \\ & 1 & 29\end{array}$

18 U.S.C. § $21,659,8802$ V-23,24,19

$135,36,31$

18 U.S.C. § 2071

V-55

67

Sec. 61-69

42 U.S.C. § 2091-2099 2

19-22

19-22

Sec. 61-69

42 U.S.C. § 2091-2099 2

19-22

19-22

18 U.S.C. § 2233

V-33

1

45

Sec. $11(x)$

42 U.S.C. § $2014(x)$

2
2

6

6

Sec. 224

74

42 U.S.C. 2274

10

74

10

Sec. 227

75

11

75

42 U.S.C. 2277 


\section{A. INDEX BY TOPIC (Cont'd)}

\begin{tabular}{|c|c|c|c|}
\hline & Citation & Vol. & Page \\
\hline \multirow[t]{4}{*}{ Receipt of } & Sec. 225 & 2 & 74 \\
\hline & & 1 & 11 \\
\hline & 42 U.S.C. 2275 & 2 & 74 \\
\hline & & 1 & 11 \\
\hline \multirow[t]{4}{*}{ Tampering With } & Sec. 226 & 2 & 74 \\
\hline & & 1 & 11 \\
\hline & 42 U.S.C. 2276 & 2 & 74 \\
\hline & & 1 & 11 \\
\hline \multirow[t]{4}{*}{ Restricted Data Def. } & Sec. $11(y)$ & 2 & 6 \\
\hline & & 1 & 1 \\
\hline & 42 U.S.C. $2014(y)$ & 2 & 6 \\
\hline & & 1 & 1 \\
\hline \multirow[t]{7}{*}{ Regulatory Prescribed Control of } & Sec. $161(e)$ & 2 & 59 \\
\hline & 42 U.S.C. $2201(\mathrm{e})$ & 2 & 59 \\
\hline & Sec. $221(a)$ & 2 & 72 \\
\hline & & 1 & 9 \\
\hline & 42 U.S.C. 2271 (a) & 2 & 72 \\
\hline & & 1 & 9 \\
\hline & Sec. 141-146 & 2 & 45-52 \\
\hline
\end{tabular}

Restrictions on Certain Facilities, etc.

of Interest to DOE

Entering

Introducing of Dangerous Weapons or Materials

Photographing, Sketching, Flying Over

Reward

Riots, Civil Disorders

$\begin{array}{llr}\text { Sec. } 221-234 a & 2 & 72-77 \\ 42 \text { U.S.C. } 2271-2282 a & 2 & 72-77 \\ \text { Sec. 221-234a } & 2 & 72-77 \\ 42 \text { U.S.C. } 2271-2282 a & 2 & 72-77 \\ 18 \text { U.S.C. } 795,796 & 2 & V-6,7 \\ & 1 & 18,19 \\ \text { Sec. } 230 & 2 & 76 \\ & 1 & 12 \\ 42 \text { U.S.C. } \S 2278 b & 2 & 76 \\ & 1 & 12 \\ & & \\ \text { 50 U.S.C. } \S 47 a & 2 & V I-3 \\ & 1 & 79 \\ \text { 18 U.S.C. } \S 231 & 2 & V-37 \\ & 1 & 49\end{array}$




\section{A. INDEX BY TOPIC (Cont'd)}

Robbery in U.S. Jurisdiction

Robbery

Rulemaking by Commission

Sabotage

Fuel Storage

Martitime Navigation

Nuclear Facilities Generally

Production Facility

Utilization Facility

Seals Broken on Railroad Cars

Searches and Seizures

Search Warrant

Assault On, or Resistance to Person Serving

Biological Weapons

Destruction or Removal of Property

Exceeding Authority in Executing

Malicious Procurement
Citation

18 U.S.C. § 2111

Vol. Page

18 U.S.C. $\S 2111,2112,2$ 2114,2119 1

V-29,30 41,42

Sec. $161(p, x)$

42 U.S.C. § $2201(p, x) \quad 2$

61,64 61,64

Sec. 236

80

42 U.S.C. § 2284

13

80

13

42 U.S.C. § 2284(a2) 2

80

13

18 U.S.C. § 2280

V-14

26

42 U.S.C. § 2284

80

13

80

13

80

13

18 U.S.C. § 659, 2117

V-24,29

36,41

see "Search Warrant"

18 U.S.C. § $111,2231 \quad 2 \quad$ V-31,32

43,44

18 U.S.C. § 176

V-35

47

18 U.S.C. § 2232

18 U.S.C. § 2234

18 U.S.C. § 2235
V-32

44

V-33

45

V-33 


\section{A. INDEX BY TOPIC (Cont'd)}

Citation

Vol. Page

Of Motor Vehicle Operator

18 U.S.C. $\S 3118$

V-33

Pen Register and Trap and Trace Device

18 U.S.C. $\S 3125$

2

1

2

1

45

V-34

46

Procuring Warrant Maliciously

18 U.S.C. § 2235

V-33

Unlawful Search Without Warrant

18 U.S.C. § 2236

45

1

2

V-33

45

18 U.S.C. $\$ 2233$

V-33

Rescue of Seized Property

2

Sec. 222

45

Unlawful search

42 U.S.C. § 2272

72

9

72

9

Security Regulations

50 U.S.C. § 797

V1-7 83

Sedition

18 U.S.C. § 2384

$V-18$ 30

Sedition Conspiracy

18 U.S.C. § $2383,2384,2$ 2385

Seizures under Warrant

See "Search Warrant"

SF (Source and Fissionable) Material

Term now obsolete.

Source Material

Definition of

Sec. $11(z)$

2

42 U.S.C. \& $2014(z) \quad 2$

Licensing of

Sec. 61-69

42 U.S.C. § 2091-2099

Sec. 62

42 U.S.C. § 2092

1

Possession

Special Maritime Jurisdiction

18 U.S.C. § 7,2111

2
1

V-58,V-29 70,41 


\section{A. INDEX BY TOPIC (Cont'd)}

Citation

Vol. Page

Special Nuclear Material Def.

Classes

Distribution to Persons

Distribution and Utilization of

License Required

Production

Prohibited Transactions

Sabotage

Unauthorized Handling by Persons

Use and Possession, Standard

Statute of Limitations

For Title 18
Sec. $11(a a)$

42 U.S.C. § 2014(aa)

Sec. 57(d)

42 U.S.C. § 2077 (d)

Sec. $57(c)$

42 U.S.C. § 2077(c)

Sec. 51, 53-58

42 U.S.C. $\$ 2071$, 2073-2078

Sec. 101

42 U.S.C. § 2131

Sec. 57(b)

42 U.S.C. § 2077 (b)

18 U.S.C. § 831

Sec. 236

42 U.S.C. § 2284

$\operatorname{Sec} 57(a)$

42 U.S.C. § $2077(a)$

Sec. 161 (b)

42 U.S.C. § 2201 (b)

18 U.S.C. § 3282,3286
26

11

26

11

$2 \quad 18$

13

$2 \quad 18$

$\begin{array}{rr}1 & 3 \\ 2 & 18\end{array}$

218

13

$2 \quad 11,11-19$

211

$2 \quad 11-19$

28

13

228

13

217

12

217

12

$2 \quad V-25$

$1 \quad 37$

280

$1 \quad 13$

280

$1 \quad 13$

$2 \quad 17$

$1 \quad 1$

217

$1 \quad 1$

258

16

258

1

6

$\mathrm{V}-58$

70 


\section{A. INDEX BY TOPIC (Cont'd)}

Citation

Vol.

Page

For Title 42, Chap. 23

Sec. 228

2

75

42 U.S.C. § 2278

$1 \quad 11$

$2 \quad 75$

1

11

Subversive Activity

18 U.S.C. § 2381-2385

2
1

V-17-18

29-30

Territorial Jurisdiction of U.S.

18 U.S.C. $\S 1363$

V-31

Terrorism

Definition

18 U.S.C. $\$ 2331$

V-55

Federal Jurisdiction

18 U.S.C. § 2338

67

V-57

69

Providing Material Support

18 U.S.C. $\S 2339 A$

V-57

69

18 U.S.C. $§ 3286$

$\mathrm{V}-58$

Statute of Limitations

18 U.S.C. $\$ 2332 \mathrm{a}$

70

Weapons of Mass Destruction

Theft from Interstate Shipment

18 U.S.C. $\$ 659,2117$

$\mathrm{V}-24,29$

36,41

Theft of Government Property

18 U.S.C. $\S 21,641,6432$

18 U.S.C. $\$ 2111,2112,2$

2114

$V-23,24$

35,36

V-29

41

Theft of Motor Vehicle

18 U.S.C. $\$ 2119$

V-30

42

Theft

18 U.S.C. § 21,641

V-23

18 U.S.C. $\$ 659$

35

By Deception

18 U.S.C. $\$ 1001$

V-24

36

By Misrepresentation

$\mathrm{V}-20$

32 


\section{A. INDEX BY TOPIC (Cont'd)}

\begin{tabular}{|c|c|c|c|}
\hline & Citation & Vol. & Page \\
\hline Treason & 18 U.S.C. § 2381 & 2 & $V-17$ \\
\hline Misprision & 18 U.S.C. § 2381 & $\begin{array}{l}1 \\
2\end{array}$ & $\begin{array}{r}29 \\
V-17 \\
20\end{array}$ \\
\hline Treason & 18 U.S.C. § 2381,2382 & $\begin{array}{l}2 \\
1\end{array}$ & $\begin{array}{r}V-17 \\
29\end{array}$ \\
\hline Trespass on Commission Installation & $\begin{array}{l}\text { Sec. } 229 \\
42 \text { U.S.C. } \$ 2278 a\end{array}$ & $\begin{array}{l}2 \\
1 \\
2 \\
1\end{array}$ & $\begin{array}{l}75 \\
12 \\
75 \\
12\end{array}$ \\
\hline Depredation Against Property & 18 U.S.C. $\S 1361$ & $\begin{array}{l}2 \\
1\end{array}$ & $\begin{array}{r}V-30 \\
42\end{array}$ \\
\hline Military Bases & 18 U.S.C. § 1382 & $\begin{array}{l}2 \\
1\end{array}$ & $\begin{array}{r}V-53 \\
65\end{array}$ \\
\hline United States, definition of & $\begin{array}{l}\text { Sec. } 11(a) \\
42 \text { U.S.C. \& } 2014(a)\end{array}$ & $\begin{array}{l}2 \\
2\end{array}$ & $\begin{array}{l}3 \\
3\end{array}$ \\
\hline Utilization Facility & $\begin{array}{l}\text { Sec. } 11(c c) \\
42 \text { U.S.C. § } 2014(c c)\end{array}$ & $\begin{array}{l}2 \\
2\end{array}$ & $\begin{array}{l}6 \\
6\end{array}$ \\
\hline Utilization of Other Federal Agencies & $\begin{array}{l}\text { Sec. } 161(f) \\
42 \text { U.S.C. § } 2201(f)\end{array}$ & $\begin{array}{l}2 \\
1 \\
2 \\
1\end{array}$ & $\begin{array}{r}59 \\
6 \\
59 \\
6\end{array}$ \\
\hline $\begin{array}{l}\text { U.S. Property } \\
\text { Communication Lines (destruction) }\end{array}$ & 18 U.S.C. § 1362 & $\begin{array}{l}2 \\
1\end{array}$ & $\begin{array}{r}V-30 \\
42\end{array}$ \\
\hline Damage or Depredation & 18 U.S.C. $\S 1361$ & $\begin{array}{l}2 \\
1\end{array}$ & $\begin{array}{r}V-30 \\
42\end{array}$ \\
\hline Destruction of War Material & 18 U.S.C. § 2153 & $\begin{array}{l}2 \\
1\end{array}$ & $\begin{array}{r}V-13 \\
25\end{array}$ \\
\hline Personal, Theft of & 18 U.S.C. § 2112 & $\begin{array}{l}2 \\
1\end{array}$ & $\begin{array}{r}V-29 \\
41\end{array}$ \\
\hline $\begin{array}{l}\text { Violations } \\
\text { Injunction to Prevent }\end{array}$ & $\begin{array}{l}\text { Sec. 232, 222, } 223 \\
42 \text { U.S.C. \& } 2280,2272, \\
2273\end{array}$ & $\begin{array}{l}2 \\
2\end{array}$ & $\begin{array}{l}76,72,73 \\
76,72,73\end{array}$ \\
\hline
\end{tabular}




\section{A. INDEX BY TOPIC (Cont'd)}

Citation

Penalties for Specific Sections

Violation Generally

Vital Naval and Military Installations

War Material Def.

National Defense Material Def.

National Defense Premises Def.

National Defense Utilities Def.

War Premises Def.

War Utilities Def.
Sec. 222

42 U.S.C. § 2272

Sec. 223

42 U.S.C. § 2273

Exec. Order 10104

18 U.S.C. $\$ 2151$

18 U.S.C. § 2151

18 U.S.C. § 2151

18 U.S.C. § 2151

18 U.S.C. § 2151

18 U.S.C. § 2151
Vol.

Page

2
1
2
1
2
1
2
1

72

9

72

9

73

9

73

1

9

2
1

V-9

21

V-11

2

23

V-11

23

V-11

23

V-11

23

V-11

23

V-11

23 


\section{B. INDEX OF SELECTED PORTIONS OF TITLE 18 OF THE CODE OF THE LAWS OF THE UNITED STATES IN NUMERICAL ORDER}

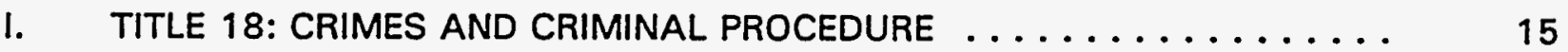

18 U.S.C. $\$ 7$. Special maritime and territorial jurisdiction of the United States defined ............. 70

18 U.S.C. $\$ 21$ Stolen or counterfeit nature of property for certain crimes defined ................

18 U.S.C. § 33. Destruction of motor vehicles or motor vehicle facilities .....................

18 U.S.C. $\$ 81 . \quad$ Arson within special maritime and territorial jurisdiction ..................

18 U.S.C. $\S 111$. Assaulting, resisting, or impeding certain officers or employees ..................

18 U.S.C. $\$ 175$. Prohibitions with respect to biological weapons ..

18 U.S.C. $\$ 176$. Seizure, forfeiture, and destruction .........

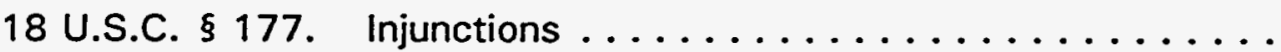

18 U.S.C. $\$ 178$. Definitions ( + Biological weapons) $\ldots . \ldots \ldots \ldots$

18 U.S.C. $\S 231$. Civil disorders $\ldots \ldots \ldots \ldots \ldots \ldots \ldots$

18 U.S.C. $\$ 371$. Conspiracy to commit offense or to defraud United States ..................

18 U.S.C. $\$ 499$. Military, naval, or official passes . . . . . . . . . .

18 U.S.C. $\$ 641$. Public money, property, or records . . . . . . . .

† Author's comments 
18 U.S.C. $\$ 643$. Accounting generally for public money ... . . . .

18 U.S.C. $\$ 659$. Interstate or foreign shipments by carrier;

State prosecutions ..............

18 U.S.C. $\$ 701$. Official badges, identification cards other insignia ...................

18 U.S.C. $\S 792$. Harboring or concealing persons ..... . . . . .

18 U.S.C. § 793. Gathering, transmitting, or losing defense

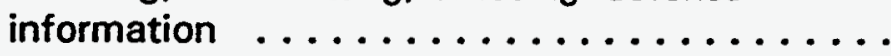

18 U.S.C. $\$ 794$. Gathering or delivering defense information to aid foreign government . . . . . . . . . . . . .

18 U.S.C. § 795. Photographing and sketching defense

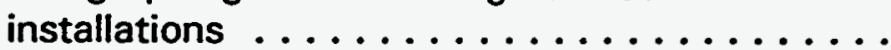

18 U.S.C. $\$ 796$. Use of aircraft for photographing defense installations $\ldots \ldots \ldots \ldots \ldots \ldots$

18 U.S.C. § 797. Publication and sale of photographs of defense

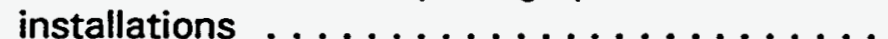

18 U.S.C. $\S 798$. Disclosure of classified information ..........

18 U.S.C. $\S 798$ A. Temporary extension of Section $794 \ldots \ldots \ldots$. .

18 U.S.C. § 831. Prohibited transactions involving nuclear materials .................

18 U.S.C. $\S 841$. Definitions (t Explosives) . . . . . . . . . . . 50

18 U.S.C. $\$ 844$. Penalties - (t Use of explosives or fires) . . . . . 51

18 U.S.C. $\$ 872$. Extortion by officers or employees of the United States ..................

$\overline{\dagger \text { Author's comments }}$ 


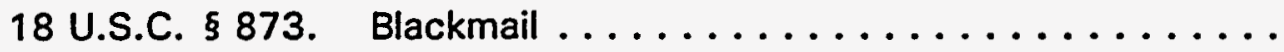

18 U.S.C. $\$ 880$. Receiving the proceeds of extortion $\ldots \ldots \ldots \ldots \quad 31$

18 U.S.C. $\S 911$. Citizen of the United States .......... 31

18 U.S.C. § 912. Officer or employee of the United States ...... 32

18 U.S.C. § 913 . Impersonator making arrest or search ...... 32

18 U.S.C. $\S 921$. Definitions - († Firearms) $\ldots \ldots \ldots \ldots \ldots \ldots .54$

18 U.S.C. $\S 927$. Effect on state law - (t Firearms) ......... 62

18 U.S.C. $\S 930$. Possession of firearms and dangerous weapons in Federal facilities ............ 62

18 U.S.C. $\$ 1001$. Statements or entries generally ......... 32

18 U.S.C. § 1031. Major fraud against the United States ....... 32

18 U.S.C. $\S 1111$. Murder $\ldots \ldots \ldots \ldots \ldots \ldots \ldots \ldots \ldots \ldots$

18 U.S.C. $\S 1112$. Manslaughter ................... 64

18 U.S.C. § 1121. Killing persons aiding Federal investigations or State correctional officers .......... 64

18 U.S.C. $\S 1361$. Government property or contracts $\ldots \ldots \ldots \ldots \quad 42$

18 U.S.C. § 1362. Communication lines, stations, or systems .. 42

18 U.S.C. § 1363. Buildings or property within special maritime and territorial jurisdiction ...............

18 U.S.C. § 1382. Entering military, Naval, or Coast Guard property $\ldots \ldots \ldots \ldots \ldots \ldots \ldots \ldots$

18 U.S.C. $\$ 1460$. Possession with intent to sell, and sale, of obscene matter on Federal property .......... 
18 U.S.C. $\S 1466$. Engaging in the business of selling or transferring obscene matter $\ldots \ldots \ldots \ldots \ldots$

18 U.S.C. $\$ 1467$. Criminal forfeiture . . . . . . . . . . . 72

18 U.S.C. $\$ 1516$. Obstruction of Federal audit ........... 34

18 U.S.C. $\S 1621$. Perjury generally ................ 34

18 U.S.C. \$ 1864. Hazardous or injurious devices on Federal lands . .

18 U.S.C. \$ 1924. Unauthorized removal and retention of classified documents or material ............. 23

18 U.S.C. § 2071. Concealment, removal, or mutilation generally ... 67

18 U.S.C. $\$ 2111$. Special maritime and territorial jurisdiction ..... 41

18 U.S.C. $\S 2112$. Personal property of United States ......... 41

18 U.S.C. § 2114. Mail, money, or other property of United States $\ldots \ldots \ldots \ldots \ldots \ldots \ldots \ldots, 41$

18 U.S.C. § 2117. Breaking or entering carrier facilities ....... 41

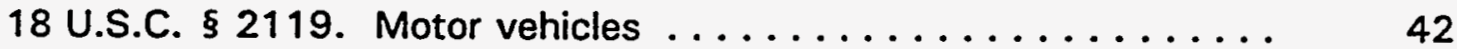

18 U.S.C. $\$ 2151$. Definitions .................... 23

18 U.S.C. $\$ 2152$. Fortifications, harbor defenses, or defensive

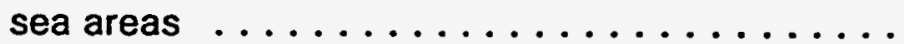

18 U.S.C. § 2153. Destruction of war material, war premises, or war

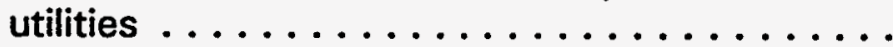

18 U.S.C. $\$ 2154$. Production of defective war material, war premises, or war utilities $\ldots \ldots \ldots \ldots \ldots \ldots \ldots$.

18 U.S.C. § 2155. Destruction of national defense materials, national defense premises, or national defense utilities .

18 U.S.C. § 2156. Production of defective national defense material, national defense premises, or national

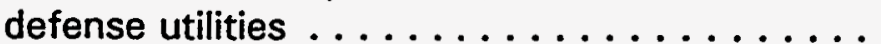

18 U.S.C. $\S 2231$. Assault or resistance ............... 
18 U.S.C. $\$ 2232$. Destruction or removal of property to Prevent

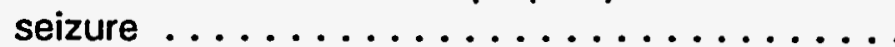

18 U.S.C. $\$ 2233$. Rescue of seized property . . . . . . . . . . . 45

18 U.S.C. $\S 2234$. Authority exceeded in executing warrant . . . . . . 45

18 U.S.C. § 2235 . Search warrant procured maliciously . . . . . . . 45

18 U.S.C. $\$ 2236$. Searches without warrant $\ldots \ldots \ldots \ldots \ldots \ldots$. . . 45

18 U.S.C. $\S 2280$. Violence against maritime navigation ... . . . . 26

18 U.S.C. $\S 2331$. Definitions (t Terrorism) $\ldots \ldots \ldots \ldots \ldots$. . . . 67

18 U.S.C. $\$ 2332$ a. Use of weapons of mass destruction ........ 68

18 U.S.C. $\$ 2338$. Exclusive Federal jurisdiction $\ldots \ldots \ldots \ldots \ldots$

18 U.S.C. $\S 2339$ A. Providing material support to terrorists ... . . . 69

18 U.S.C. $\$ 2381$. Treason . . . . . . . . . . . . . . . . . 29

18 U.S.C. $\$ 2382$. Misprision of treason . . . . . . . . . . . . 29

18 U.S.C. $\S 2383$. Rebellion or insurrection .............. 29

18 U.S.C. $\$ 2384$. Seditious conspiracy . . . . . . . . . . . 30

18 U.S.C. § 2385. Advocating overthrow of Government . . . . . . 30

18 U.S.C. $\S 3118$. Implied consent for certain tests . . . . . . . . . 45

18 U.S.C. $\$ 3125$. Emergency pen register and trap and trace device installation .................. 46

18 U.S.C. $\S 3281$. Capital offenses ................. 70

18 U.S.C. $\S 3282$. Offenses not capital ................ 70

18 U.S.C. $\$ 3286$. Extension of statute of limitation for certain terrorism offenses ............... 
-xxxviii-

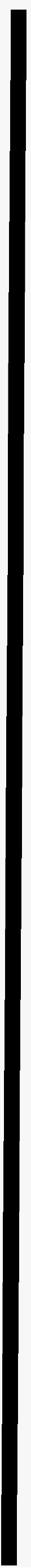




\section{TITLE 42. UNITED STATES CODE \\ (ATOMIC ENERGY ACT OF 1954 AS AMENDED)}

\section{SELECTED ENFORCEMENT PROVISIONS}

\section{U.S.C. $\$ 2014$ (Section 11). Definitions}

The intent of Congress in the definitions as given in this section should be construed from the words or phrases used in the definitions. As used in this Act:

(c) The term "atomic energy" means all forms of energy released in the course of nuclear fission or nuclear transformation.

(i) The term "design" means (1) specifications, plans, drawings, blueprints, and other items of like nature; (2) the information contained therein; or (3) the research and development data pertinent to the information contained therein.

(y) The term "Restricted Data" means all data concerning (1) design, manufacture, or utilization of atomic weapons; (2) the production of special nuclear material; or (3) the use of special nuclear material in the production of energy, but shall not include data declassified or removed from the Restricted Data category pursuant to section 142 [42 U.S.C. § 2162].

(z) The term "source material" means (1) uranium, thorium, or any other material which is determined by the Commission pursuant to the provisions of section 61 [42 U.S.C. $\S 2091$ ] to be source material; or (2) ores containing one or more of the foregoing materials, in such concentration as the Commission may by regulation determine from time to time.

(aa) The term "special nuclear material" means (1) plutonium, uranium enriched in the isotope 233 or in the isotope 235, and any other material which the Commission, pursuant to the provisions of section 51 [42 U.S.C. $\$ 2071$ ], determines to be special nuclear material, but does not include source material; or (2) any material artificially enriched by any of the foregoing, but does not include source material.

\section{U.S.C. \& 2077 (Sec. 57). Prohibition}

(a) Possession without license. Unless authorized by a general or specific license issued by the Commission, which the Commission is authorized to issue pursuant to section 53 [42 U.S.C. § 2073], no person may transfer or receive in interstate commerce, transfer, deliver, acquire, own, possess, receive possession of or title to, or import into or export from the United States any special nuclear material.

\footnotetext{
'Section numbers refer to the corresponding section of the Atomic Energy Act of 1954.
} 
(b) Production. It shall be unlawful for any person to directly or indirectly engage in the production of any special nuclear material outside of the United States except (1) as specifically authorized under an agreement for cooperation made pursuant to section 123 [42 U.S.C. \$ 2153], including a specific authorization in a subsequent arrangement under section 131 of this Act [42 U.S.C. $\S 2160$ ], or (2) upon authorization by the Secretary of Energy after a determination that such activity will not be inimical to the interest of the United States: Provided, That any such determination by the Secretary of Energy shall be made only with the concurrence of the Department of State and after consultation with the Arms Control and Disarmament Agency, the Nuclear Regulatory Commission, the Department of Commerce, and the Department of Defense. The Secretary of Energy shall, within ninety days after the enactment of the Nuclear Non-Proliferation Act of 1978 [enacted Mar. 10, 1978], establish orderly and expeditious procedures, including provision for necessary administrative actions and inter-agency memoranda of understanding, which are mutually agreeable to the Secretaries of State, Defense, and Commerce, the Director of the Arms Control and Disarmament Agency, and the Nuclear Regulatory Commission for the consideration of requests for authorization under this subsection. Such procedures shall include, at a minimum, explicit direction on the handling of such requests, express deadlines for the solicitation and collection of the views of the consulted agencies (with identified officials responsible for meeting such deadlines), an interagency coordinating authority to monitor the processing of such requests, predetermined procedures for the expeditious handling of intra-agency and inter-agency disagreements and appeals to higher authorities, frequent meetings of inter-agency administrative coordinators to review the status of all pending requests, and similar administrative mechanisms. To the extent practicable, an applicant should be advised of all the information required of the applicant for the entire process for every agency's needs at the beginning of the process. Potentially controversial requests should be identified as quickly as possible so that any required policy decisions or diplomatic consultations can be initiated in a timely manner. An immediate effort should be undertaken to establish quickly any necessary standards and criteria, including the nature of any required assurances or evidentiary showings, for the decision required under this subsection. The processing of any request proposed and filed as of the date of enactment of the Nuclear Non-Proliferation Act of 1978 [enacted Mar. 10, 1978] shall not be delayed pending the development and establishment of procedures to implement the requirements of this subsection. Any trade secrets or proprietary information submitted by any person seeking an authorization under this subsection shall be afforded the maximum degree of protection allowable by law: Provided further, That the export of component parts as defined in subsection $11 \mathrm{v}$. (2) or $11 \mathrm{cc}$. (2) [42 U.S.C. $\S 2014(v)(2)$, or $2014(\mathrm{cc})(2)]$ shall be governed by sections 109 and 126 of this Act [42 U.S.C. $\S \S 2139$ and 2155]: Provided further, That notwithstanding subsection 402(d) of the Department of Energy Organization Act (Public Law 95-91) [42 U.S.C. $\$ 7172$ (d)] the Secretary of Energy and not the Federal Energy Regulatory Commission, shall have sole jurisdiction within the Department of Energy over any matter arising from any function of the Secretary of Energy in this section, section 54 d. [42 U.S.C. \$ 2074d.], section 64 [42 U.S.C. § 2094], or section 111 b [42 U.S.C. $\S 2141$ b.]. 
(c) Distribution. The Commission shall not--

(1) distribute any special nuclear material to any person for a use which is not under the jurisdiction of the United States except pursuant to the provisions of section 54 [42 U.S.C. § 2074]; or

(2) distribute any special nuclear material or issue a license pursuant to section 53 [42 U.S.C. § 2073] to any person within the United States if the Commission finds that the distribution of such special nuclear material or the issuance of such license would be inimical to the common defense and security or would constitute an unreasonable risk to the health and safety of the public.

(d) Establishment of classes of special nuclear materials. The Commission is authorized to establish classes of special nuclear material and to exempt certain classes or quantities of special nuclear material or kinds of uses or users from the requirements for a license set forth in this section when it makes a finding that the exemption of such classes or quantities of special nuclear material or such kinds of uses or users would not be inimical to the common defense and security and would not constitute an unreasonable risk to the health and safety of the public.

(e) Special nuclear material, as defined in section 11 [42 U.S.C. § 2014], produced in facilities licensed under section 103 or 104 [42 U.S.C. \$ \$2133, 2134] may not be transferred, reprocessed, used, or otherwise made available by any instrumentality of the United States or any other person for nuclear explosive purposes.

\section{U.S.C. § 2122 (Sec. 92). Prohibition}

It shall be unlawful, except as provided in section 91 [42 U.S.C. \$ 2121], for any person to transfer or receive in interstate or foreign commerce, manufacture, produce, transfer, acquire, possess, import, or export any atomic weapon. Nothing in this section shall be deemed to modify the provisions of subsection 31 (a) or section 101 [42 U.S.C. $\S \S 2051$ (a), 2131].

\section{U.S.C. § 2131 (Sec. 101). License required}

It shall be unlawful, except as provided in section 91 [42 U.S.C. \$ 2121], for any person within the United States to transfer or receive in interstate commerce, manufacture, produce, transfer, acquire, possess, use, import, or export any utilization or production facility except under and in accordance with a license issued by the Commission pursuant to section 103 or 104 [42 U.S.C. $\S \S 2133,2134$ ].

42 U.S.C. § 2133 (Sec. 103). Commercial licenses

(a) Conditions. The Commission is authorized to issue licenses to persons applying therefor to transfer or receive in interstate commerce, manufacture, produce, transfer, acquire, possess, use, import, or export under the terms of an agreement for cooperation arranged pursuant to section 123 [42 U.S.C. § 2153], utilization or 
production facilities for industrial or commercial purposes. Such licenses shall be issued in accordance with the provisions of chapter 16 [42 U.S.C. § $\$ 2231$ et seq.] and subject to such conditions as the Commission may by rule or regulation establish to effectuate the purposes and provisions of this Act.

(b) Nonexclusive basis. The Commission shall issue such licenses on a nonexclusive basis to persons applying therefor (1) whose proposed activities will serve a useful purpose proportionate to the quantities of special nuclear material or source material to be utilized; (2) who are equipped to observe and who agree to observe such safety standards to protect health and to minimize danger to life or property as the Commission may by rule establish; and (3) who agree to make available to the Commission such technical information and data concerning activities under such licenses as the Commission may determine necessary to promote the common defense and security and to protect the health and safety of the public. All such information may be used by the Commission only for the purposes of the common defense and security and to protect the health and safety of the public.

(c) License period. Each such license shall be issued for a specified period, as determined by the Commission, depending on the type of activity to be licensed, but not exceeding forty years, and may be renewed upon the expiration of such period.

(d) Limitations. No license under this section may be given to any person for activities which are not under or within the jurisdiction of the United States, except for the export of production or utilization facilities under terms of an agreement for cooperation arranged pursuant to section 123 [42 U.S.C. \& 2153], or except under the provisions of section 109 [42 U.S.C. \$ 2139]. No license may be issued to an alien or any corporation or other entity if the Commission knows or has reason to believe it is owned, controlled, or dominated by an alien, a foreign corporation, or a foreign government. In any event, no license may be issued to any person within the United States if, in the opinion of the Commission, the issuance of a license to such person would be inimical to the common defense and security or to the health and safety of the public.

[(e)](f) Notice in event of accidents which could result in accidental release of contaminants. Each license issued for a utilization facility under this section or section $104 \mathrm{~b}$. [42 U.S.C. $\S 2134(\mathrm{~b})]$ shall require as a condition thereof that in case of any accident which could result in an unplanned release of quantities of fission products in excess of allowable limits for normal operation established by the Commission, the licensee shall immediately so notify the Commission. Violation of the condition prescribed by this subsection may, in the Commission's discretion, constitute grounds for license revocation. In accordance with section 187 of this Act [42 U.S.C. § 2237], the Commission shall promptly amend each license for a utilization facility issued under this section or section 104 b. [42 U.S.C. $\$ 2134(\mathrm{~b})$ ] which is in effect on the date of enactment of this subsection [enacted June 30,1980 ] to include the provisions required under this subsection. 
(a) The Commission is authorized to issue licenses to persons applying therefor for utilization facilities for use in medical therapy. In issuing such licenses the Commission is directed to permit the widest amount of effective medical therapy possible with the amount of special nuclear material available for such purposes and to impose the minimum amount of regulation consistent with its obligations under this Act to promote the common defense and security and to protect the health and safety of the public.

(b) As provided for in subsection 102(b) or 102(c) [42 U.S.C. ₹ 2132(b) or (c)], or where specifically authorized by law, the Commission is authorized to issue licenses under this subsection to persons applying therefor for utilization and production facilities for industrial and commercial purposes. In issuing licenses under this subsection, the Commission shall impose the minimum amount of such regulations and terms of license as will permit the Commission to fulfill its obligations under this Act.

(c) The Commission is authorized to issue licenses to persons applying therefor for utilization and production facilities useful in the conduct of research and development activities of the types specified in section 31 [42 U.S.C. \$ 2051] and which are not facilities of the type specified in subsection 104(b) [subsec. (b) of this section]. The Commission is directed to impose only such minimum amount of regulation of the licensee as the Commission finds will permit the Commission to fulfill its obligations under this Act to promote the common defense and security and to protect the health and safety of the public and will permit the conduct of widespread and diverse research and development.

(d) No license under this section may be given to any person for activities which are not under or within the jurisdiction of the United States, except for the export of production or utilization facilities under terms of an agreement for cooperation arranged pursuant to section 123 [42 U.S.C. \$ 2153] or except under the provisions of section 109 [42 U.S.C. \$ 2139]. No license may be issued to any corporation or other entity if the Commission knows or has reason to believe it is owned, controlled, or dominated by an alien, a foreign corporation, or a foreign government. In any event, no license may be issued to any person within the United States if, in the opinion of the Commission, the issuance of a license to such person would be inimical to the common defense and security or to the health and safety of the public.

\section{U.S.C. $\$ 2138$ (Sec. 108). War or national emergency}

Whenever the Congress declares that a state of war or national emergency exists, the Commission is authorized to suspend any licenses granted under this Act if in its judgment such action is necessary to the common defense and security. The Commission is authorized during such period, if the Commission finds it necessary to the common defense and security, to order the recapture of any special nuclear material or to order the operation of any facility licensed under section 103 or 104 [42 U.S.C. $\S \S 2133,2134$ ], and is authorized to order the entry into any plant or facility in order to recapture such material, or to operate such facility. Just compensation shall be paid for any damages caused by the recapture of any special nuclear material or by the operation of any such facility. 
In the performance of its functions the Commission is authorized to--

(a) Advisory boards. establish advisory boards to advise with and make recommendations to the Commission on legislation, policies, administration, research, and other matters, provided that the Commission issues regulations setting forth the scope, procedure, and limitations of the authority of each such board;

(b) Standards and instructions. Establish by rule, regulation, or order, such standards and instructions to govern the possession and use of special nuclear material, source material, and byproduct material as the Commission may deem necessary or desirable to promote the common defense and security or to protect health or to minimize danger to life or property; in addition, the Commission shall prescribe such regulations or orders as may be necessary or desirable to promote the Nation's common defense and security with regard to control, ownership, or possession of any equipment or device, or important component part especially designed for such equipment or device, capable of separating the isotopes of uranium or enriching uranium in the isotope 235;

(c) Studies and investigations. make such studies and investigations, obtain such information, and hold such meetings or hearings as the Commission may deem necessary or proper to assist it in exercising any authority provided in this Act, or in the administration or enforcement of this Act, or any regulations or orders issued thereunder. For such purposes the Commission is authorized to administer oaths and affirmations, and by subpena to require any person to appear and testify, or to appear and produce documents, or both, at any designated place. Witnesses subpenaed under this subsection shall be paid the same fees and mileage as are paid witnesses in the district courts of the United States;

(d) N/A

(e) N/A

(f) Utilization or employment of services or personnel of other agencies or voluntary personnel. with the consent of the agency concerned, utilize or employ the services or personnel of any Government agency or any State or local government, or voluntary or uncompensated personnel, to perform such functions on its behalf as may appear desirable;

(g) N/A

(h) N/A

(i) Regulations or orders. prescribe such regulations or orders as it may deem necessary (1) to protect Restricted Data received by any person in connection with any activity authorized pursuant to this Act, (2) to guard against the loss or diversion of any special nuclear material acquired by any person pursuant to section 53 [42 U.S.C. § 2073] or produced by any person in connection with any activity authorized pursuant to this 
Act, to prevent any use or disposition thereof which the Commission may determine to be inimical to the common defense and security, including regulations or orders designating activities, involving quantities of special nuclear material which in the opinion of the Commission are important to the common defense and security, that may be conducted only by persons whose character, associations, and loyalty shall have been investigated under standards and specifications established by the Commission and as to whom the Commission shall have determined that permitting each such person to conduct the activity will not be inimical to the common defense and security, and (3) to govern any activity authorized pursuant to this Act, including standards and restrictions governing the design, location, and operation of facilities used in the conduct of such activity, in order to protect health and to minimize danger to life or property;

(j) Disposition of radioactive materials and other property. without regard to the provisions of the Federal Property and Administrative Services Act of 1949, as amended, except section 207 of that Act [40 U.S.C. § 488], or any other law, make such disposition as it may deem desirable of (1) radioactive materials, and (2) any other property, the special disposition of which is, in the opinion of the Commission, in the interest of the national security: Provided, however, That the property furnished to licensees in accordance with the provisions of subsection $161(\mathrm{~m})$ [subsec. $(\mathrm{m})$ of this section] shall not be deemed to be property disposed of by the Commission pursuant to this subsection;

(k) Carrying of firearms. authorize such of its members, officers, and employees as it deems necessary in the interest of the common defense and security to carry firearms while in the discharge of their official duties. The Commission may also authorize such of those employees of its contractors and subcontractors (at any tier) engaged in the protection of property under the jurisdiction of the United States located at facilities owned by or contracted to the United States or being transported to or from such facilities as it deems necessary in the interests of the common defense and security to carry firearms while in the discharge of their official duties. A person authorized to carry firearms under this subsection may, while in the performance of, and in connection with, official duties, make arrests without warrant for any offense against the United States committed in that person's presence or for any felony cognizable under the laws of the United States if that person has reasonable grounds to believe that the individual to be arrested has committed or is committing such felony. An employee of a contractor or subcontractor authorized to carry firearms under this subsection may make such arrests only when the individual to be arrested is within, or in direct flight from, the area of such offense. A person granted authority to make arrests by this subsection may exercise that authority only in the enforcement of (1) laws regarding the property of the United States in the custody of the Department of Energy, the Nuclear Regulatory Commission, or a contractor of the Department of Energy or Nuclear Regulatory Commission, or (2) any provision of this Act that may subject an offender to a fine, imprisonment, or both. The arrest authority conferred by this subsection is in addition to any arrest authority under other laws. The Secretary, with the approval of the Attorney General, shall issue guidelines to implement this subsection; 
(m) Agreements with licensees. enter into agreements with persons licensed under section $103,104,53(a)(4)$, or $63(a)(4)$ [42 U.S.C. \$ \$ 2133, 2134, 2073(a)(4), or 2093(a)(4)] for such periods of time as the Commission may deem necessary or desirable (1) to provide for the processing, fabricating, separating, or refining in facilities owned by the Commission of source, byproduct, or other material or special nuclear material owned by or made available to such licensees and which is utilized or produced in the conduct of the licensed activity, and (2) to sell, lease, or otherwise make available to such licensees such quantities of source or byproduct material, and other material not defined as special nuclear material pursuant to this Act, as may be necessary for the conduct of the licensed activity: Provided, however, That any such agreement may be canceled by the licensee at any time upon payment of such reasonable cancellation charges as may be agreed upon by the licensee and the Commission: And provided further, That the Commission shall establish prices to be paid by licensees for material or services to be furnished by the Commission pursuant to this subsection, which prices shall be established on such a nondiscriminatory basis as, in the opinion of the Commission, will provide reasonable compensation to the Government for such material or services and will not discourage the development of sources of supply independent of the Commission;

(n) Delegation of functions. delegate to the General Manager or other officers of the Commission any of those functions assigned to it under this Act except those specified in section 51, 57(b), 61, 108, 123, 145(b) [42 U.S.C. $\$ \$ 2071,2077$ (b), 2091, $2138,2153,2165(\mathrm{~b})]$ (with respect to the determination of those persons to whom the Commission may reveal Restricted Data in the national interest), $145(f)$ [42 U.S.C. $\S 2165(f)$ ], and 161 (a) [subsec. (a) of this section].

(o) Reports and records. require by rule, regulation, or order, such reports, and the keeping of such records with respect to, and to provide for such inspections of, activities and studies of types specified in section 31 [42 U.S.C. § 2051] and of activities under licenses issued pursuant to sections 53, 63, 81, 103, and 104 [42 U.S.C. $\S \S 2073,2093,2111,2133,2134]$, as may be necessary to effectuate the purposes of this Act, including section 105 [42 U.S.C. $\$ 2135$ ]; and

(p) Rules and regulations. make, promulgate, issue, rescind, and amend such rules and regulations as may be necessary to carry out the purposes of this Act.

(q) N/A

NOTE: The remainder of 42 U.S.C. 2201 (Sec. 161) as well as previous sections marked N/A, which have no relevance to enforcement provisions have been deleted from this volume. For a complete text see Volume 2. 
(a) To protect against the unlawful dissemination of Restricted Data and to safeguard facilities, equipment, materials, and other property of the Commission, the President shall have authority to utilize the services of any Government agency to the extent he may deem necessary or desirable.

(b) The Federal Bureau of Investigation of the Department of Justice shall investigate all alleged or suspected criminal violations of this Act.

(c) No action shall be brought against any individual or person for any violation under this Act unless and until the Attorney General of the United States has advised the Commission with respect to such action and no such action shall be commenced except by the Attorney General of the United States: Provided, however, That nothing in this subsection shall be construed as applying to administrative action taken by the Commission.

\section{U.S.C. $\$ 2272$ (Sec. 222). Violation of specific sections}

Whoever willfully violates, attempts to violate, or conspires to violate, any provision of sections 57,92 , or 101 [42 U.S.C. $\S \S 2077,2122,2131$ ], or whoever unlawfully interferes, attempts to interfere, or conspires to interfere with any recapture or entry under section 108 [42 U.S.C. \$ 2138], shall, upon conviction thereof, be punished by a fine of not more than $\$ 10,000$ or by imprisonment for not more than ten years, or both, except that whoever commits such an offense with intent to injure the United States or with intent to secure an advantage to any foreign nation shall, upon conviction thereof, be punished by imprisonment for life, or by imprisonment for any term of years or a fine of not more than $\$ 20,000$ or both.

\section{U.S.C. $\$ 2273$ (Sec. 223). Violation of sections generally}

(a) Whoever willfully violates, attempts to violate, or conspires to violate, any provision of this Act for which no criminal penalty is specifically provided or of any regulation or order prescribed or issued under section 65 or subsections 161 (b), (i), or (o) [42 U.S.C. $\S \S 2095,2201$ (b), (i), (o)] shall, upon conviction thereof, be punished by a fine of not more than $\$ 5,000$ or by imprisonment for not more than two years, or both, except that whoever commits such an offense with intent to injure the United States or with intent to secure an advantage to any foreign nation, shall, upon conviction thereof, be punished by a fine of not more than $\$ 20,000$ or by imprisonment for not more than twenty years, or both.

(b) Any individual director, officer, or employee of a firm constructing, or supplying the components of any utilization facility required to be licensed under section 103 or 104 b. of this Act [42 U.S.C. $\S \S 2133$ or $2134(\mathrm{~b})]$ who by act or omission, in connection with such construction or supply, knowingly and willfully violates or causes to be violated, any section of this Act, any rule, regulation, or order issued thereunder, or any license condition, which violation results, or if undetected could have resulted, in a significant impairment of a basic component of such a facility shall, upon conviction, be subject to a fine of not more than $\$ 25,000$ for each day of violation, or to 
imprisonment not to exceed two years, or both. If the conviction is for a violation committed after a first conviction under this subsection, punishment shall be a fine of not more than $\$ 50,000$ per day of violation, or imprisonment for not more than two years, or both. For the purposes of this subsection, the term 'basic component' means a facility structure, system, component or part thereof necessary to assure--

(1) the integrity of the reactor coolant pressure boundary,

(2) the capability to shut-down the facility and maintain it in a safe shut-down condition, or

the capability to prevent or mitigate the consequences of accidents which could result in an unplanned offsite release of quantities of fission products in excess of the limits established by the Commission.

The provisions of this subsection shall be prominently posted at each site where a utilization facility required to be licensed under section 103 or $104 \mathrm{~b}$. of this Act [42 U.S.C. $\$ \S 2133$ or $2134(b)$ ] is under construction and on the premises of each plant where components for such a facility are fabricated.

(c) Any individual director, officer or employee of a person indemnified under an agreement of indemnification under section 170 d. [42 U.S.C. $\$ 2210$ (d)] (or of a subcontractor or supplier theretol who, by act or omission, knowingly and willfully violates or causes to be violated any section of this Act or any applicable nuclear safety-related rule, regulation or order issued thereunder by the Secretary of Energy (or expressly incorporated by reference by the Secretary for purposes of nuclear safety, except any rule, regulation, or order issued by the Secretary of Transportation), which violation results in or, if undetected, would have resulted in a nuclear incident as defined in subsection 11 q. [42 U.S.C. \$ 2014(q)] shall, upon conviction, notwithstanding section 3571 of title 18 , United States Code, be subject to a fine of not more than $\$ 25,000$, or to imprisonment not to exceed two years, or both. If the conviction is for a violation committed after the first conviction under this subsection, notwithstanding section 3571 of title 18 , United States Code, punishment shall be a fine of not more than $\$ 50,000$, or imprisonment for not more than five years, or both.

\section{U.S.C. $\$ 2274$ (Sec. 224). Communication of Restricted Data}

Whoever, lawfully or unlawfully, having possession of, access to, control over, or being entrusted with any document, writing, sketch, photograph, plan, model, instrument, appliance, note, or information involving or incorporating Restricted Data--

(a) communicates, transmits, or discloses the same to any individual or person, or attempts or conspires to do any of the foregoing, with intent to injure the United States or with intent to secure an advantage to any foreign nation, upon conviction thereof, shall be punished by imprisonment for life, or by imprisonment for any term of years or a fine of not more than $\$ 20,000$ or both; 
(b) communicates, transmits, or discloses the same to any individual or person, or attempts or conspires to do any of the foregoing, with reason to believe such data will be utilized to injure the United States or to secure an advantage to any foreign nation, shall, upon conviction, be punished by a fine of not more than $\$ 10,000$ or imprisonment for not more than ten years, or both.

\section{U.S.C. § 2275 (Sec. 225). Receipt of Restricted Data}

Whoever, with intent to injure the United States or with intent to secure an advantage to any foreign nation, acquires, or attempts or conspires to acquire any document, writing, sketch, photograph, plan, model, instrument, applicance, note, or information involving or incorporating Restricted Data shall, upon conviction thereof, be punished by imprisonment for life, or by imprisonment for any term of years or a fine of not more than $\$ 20,000$ or both.

\section{U.S.C. $\$ 2276$ (Sec. 226). Tampering with Restricted Data}

Whoever, with intent to injure the United States or with intent to secure an advantage to any foreign nation, removes, conceals, tampers with, alters, mutilates, or destroys any document, writing, sketch, photograph, plan, model, instrument, appliance, or note involving or incorporating Restricted Data and used by any individual or person in connection with the production of special nuclear material, or research or development relating to atomic energy, conducted by the United States, or financed in whole or in part by Federal funds, or conducted with the aid of special nuclear material, shall be punished by imprisonment for life, or by imprisonment for any term of years or a fine of not more than $\$ 20,000$ or both.

\section{U.S.C. $\$ 2277$ (Sec. 227). Disclosure of Restricted Data}

Whoever, being or having been an employee or member of the Commission, a member of the Armed Forces, an employee of any agency of the United States, or being or having been a contractor of the Commission or of an agency of the United States, or being or having been an employee of a contractor of the Commission or of an agency of the United States, or being or having been a licensee of the Commission, or being or having been an employee of a licensee of the Commission, knowingly communicates, or whoever conspires to communicate or to receive, any Restricted Data, knowing or having reason to believe that such data is Restricted Data, to any person not authorized to receive Restricted Data, pursuant to the provisions of this Act or under rule or regulation of the Commission issued pursuant thereto, knowing or having reason to believe such person is not so authorized to receive Restricted Data shall, upon conviction thereof, be punishable by a fine of not more than $\$ 2,500$.

\section{U.S.C. $\S 2278$ (Sec. 228). Statute of limitations}

Except for a capital offense, no individual or person shall be prosecuted, tried, or punished for any offense prescribed or defined in sections 224 to 226 , inclusive, of this Act [42 U.S.C. $\S \S$ 2274--2276] unless the indictment is found or the information is instituted within ten years next after such offense shall have been committed. 
(a) The Commission is authorized to issue regulations relating to the entry upon or carrying, transporting, or otherwise introducing or causing to be introduced any dangerous weapon, explosive, or other dangerous instrument or material likely to produce substantial injury or damage to persons or property, into or upon any facility, installation, or real property subject to the jurisdiction, administration, or in the custody of the Commission. Every such regulation of the Commission shall be posted conspicuously at the location involved.

(b) Whoever shall willfully violate any regulation of the Commission issued pursuant to subsection (a) shall, upon conviction thereof, be punishable by a fine of not more than $\$ 1,000$.

(c) Whoever shall willfully violate any regulation of the Commission issued pursuant to subsection (a) with respect to any installation or other property which is enclosed by a fence, wall, floor, roof, or other structural barrier shall be guilty of a misdemeanor and upon conviction thereof shall be punished by a fine of not to exceed $\$ 5,000$ or to imprisonment for not more than one year, or both.

\section{U.S.C. $\$ 2278 b$ (Sec. 230). Photographing of installations}

It shall be an offense, punishable by a fine of not more than $\$ 1,000$ or imprisonment for not more than one year, or both--

(1) to make any photograph, sketch, picture, drawing, map or graphical representation, while present on property subject to the jurisdiction, administration or in the custody of the Commission, of any installations or equipment designated by the President as requiring protection against the general dissemination of information relative thereto, in the interest of the common defense and security, without first obtaining the permission of the Commission, and promptly submitting the product obtained to the Commission for inspection or such other action as may be deemed necessary; or

(2) to use or permit the use of an aircraft or any contrivance used, or designed for navigation or flight in air, for the purpose of making a photograph, sketch, picture, drawing, map or graphical representation of any installation or equipment designated by the President as provided in the preceding paragraph, unless authorized by the Commission.

42 U.S.C. $\$ 2279$ (Sec. 231). Other laws

Sections 224 to 230 [42 U.S.C. $\S \S 2274--2278$ b] shall not exclude the applicable provisions of any other laws. 
(a) Whoever kills any person who performs any inspections which--

(1) are related to any activity or facility licensed by the Commission, and

(2) are carried out to satisfy requirements under this Act or under any other Federal law governing the safety of utilization facilities required to be licensed under section 103 or 104 b., or the safety of radioactive materials,

shall be punished as provided under sections 1111 and 1112 of title 18 , United States Code [18 U.S.C. $\S \S 1111,1112$ ]. The preceding sentence shall be applicable only if such person is killed while engaged in the performance of such inspection duties or on account of the performance of such duties.

(b) Whoever forcibly assaults, resists, opposes, impedes, intimidates, or interferes with any person who performs inspections as described under subsection a. of this section, while such person is engaged in such inspection duties or on account of the performance of such duties, shall be punished as provided under section 111 of title 18, United States Code [18 U.S.C. § 111].

42 U.S.C. $\$ 2284$ (Sec. 236). Sabotage of nuclear facilities or fuel

a. Any person who intentionally and willfully destroys or causes physical damage to, or who intentionally and willfully attempts to destroy or cause physical damage to--

(1) any production facility or utilization facility licensed under this Act;

(2) any nuclear waste storage facility licensed under this Act;

(3) any nuclear fuel for such a utilization facility, or any spent nuclear fuel from such a facility; or

(4) any uranium enrichment facility licensed by the Nuclear Regulatory Commission.

shall be fined not more than $\$ 10,000$ or imprisoned for not more than ten years, or both.

b. Any person who intentionally and willfully causes or attempts to cause an interruption of normal operation of any such facility through the unauthorized use of or tampering with the machinery, components, or controls of any such facility, shall be fined not more than $\$ 10,000$ or imprisoned for not more than ten years, or both. 
$-14-$ 


\section{TITLE 18. CRIMES AND CRIMINAL PROCEDURE - UNITED STATES CODE}

\section{A. ESPIONAGE AND CENSORSHIP}

\section{U.S.C. \$ 792. Harboring or concealing persons}

Whoever harbors or conceals any person who he knows, or has reasonable grounds to believe or suspect, has committed, or is about to commit, an offense under sections 793 or 794 of this title, shall be fined under this title or imprisoned not more than ten years, or both.

\section{U.S.C. $₹$ 793. Gathering, transmitting, or losing defense information}

(a) Whoever, for the purpose of obtaining information respecting the national defense with intent or reason to believe that the information is to be used to the injury of the United States, or to the advantage of any foreign nation, goes upon, enters, flies over, or otherwise obtains information concerning any vessel, aircraft, work of defense, navy yard, naval station, submarine base, fueling station, fort, battery, torpedo station, dockyard, canal, railroad, arsenal, camp, factory, mine, telegraph, telephone, wireless, or signal station, building, office, research laboratory or station or other place connected with the national defense owned or constructed, or in progress of construction by the United States or under the control of the United States, or of any of its officers, departments, or agencies, or within the exclusive jurisdiction of the United States, or any place in which any vessel, aircraft, arms, munitions, or other materials or instruments for use in time of war are being made, prepared, repaired, stored, or are the subject of research or development, under any contract or agreement with the United States, or any department or agency thereof, or with any person on behalf of the United States, or otherwise on behalf of the United States, or any prohibited place so designated by the President by proclamation in time of war or in case of national emergency in which anything for the use of the Army, Navy, or Air Force is being prepared or constructed or stored, information as to which prohibited place the President has determined would be prejudicial to the national defense; or

(b) Whoever, for the purpose aforesaid, and with like intent or reason to believe, copies, takes, makes, or obtains, or attempts to copy, take, make, or obtain any sketch, photograph, photographic negative, blueprint, plan, map, model, instrument, appliance, document, writing, or note of anything connected with the national defense; or

(c) Whoever, for the purpose aforesaid, receives or obtains or agrees or attempts to receive or obtain from any person, or from any source whatever, any document, writing, code book, signal book, sketch, photograph, photographic negative, blueprint, plan, map, model, instrument, appliance, or note, of anything connected with the national defense, knowing or having reason to believe, at the time he receives or obtains, or agrees or attempts to receive or obtain it, that it has been or will be obtained, taken, made, or disposed of by any person contrary to the provisions of this chapter [18 U.S.C. $\S \S 792$ et seq.]; or 
(d) Whoever, lawfully having possession of, access to, control over, or being entrusted with any document, writing, code book, signal book, sketch, photograph, photographic negative, blueprint, plan, map, model, instrument, appliance, or note relating to the national defense, or information relating to the national defense which information the possessor has reason to believe could be used to the injury of the United States or to the advantage of any foreign nation, willfully communicates, delivers, transmits or causes to be communicated, delivered, or transmitted or attempts to communicate, deliver, transmit or cause to be communicated, delivered or transmitted the same to any person not entitled to receive it, or willfully retains the same and fails to deliver it on demand to the officer or employee of the United States entitled to receive it; or

(e) Whoever having unauthorized possession of, access to, or control over any document, writing, code book, signal book, sketch, photograph, photographic negative, blueprint, plan, map, model, instrument, appliance, or note relating to the national defense, or information relating to the national defense which information the possessor has reason to believe could be used to the injury of the United States or to the advantage of any foreign nation, willfully communicates, delivers, transmits or causes to be communicated, delivered, or transmitted, or attempts to communicate, deliver, transmit or cause to be communicated, delivered, or transmitted the same to any person not entitled to receive it, or willfully retains the same and fails to deliver it to the officer or employee of the United States entitled to receive it; or

(f) Whoever, being entrusted with or having lawful possession or control of any document, writing, code book, signal book, sketch, photograph, photographic negative, blueprint, plan, map, model, instrument, appliance, note, or information, relating to the national defense, (1) through gross negligence permits the same to be removed from its proper place of custody or delivered to anyone in violation of his trust, or to be lost, stolen, abstracted, or destroyed, or (2) having knowledge that the same has been illegally removed from its proper place of custody or delivered to anyone in violation of his trust, or lost, or stolen, abstracted, or destroyed, and fails to make prompt report of such loss, theft, abstraction, or destruction to his superior officer--

Shall be fined under this title or imprisoned not more than ten years, or both.

(g) If two or more persons conspire to violate any of the foregoing provisions of this section, and one or more of such persons do any act to effect the object of the conspiracy, each of the parties to such conspiracy shall be subject to the punishment provided for the offense which is the object of such conspiracy.

(h)(1) Any person convicted of a violation of this section shall forfeit to the United States, irrespective of any provision of State law, any property constituting, or derived from, any proceeds the person obtained, directly or indirectly, from any foreign government, or any faction or party or military or naval force within a foreign country, whether recognized or unrecognized by the United States, as the result of such violation. 
(2) The court, in imposing sentence on a defendant for a conviction of a violation of this section, shall order that the defendant forfeit to the United States all property described in paragraph (1) of this subsection.

(3) The provisions of subsections (b), (c), and (e) through (o) of section 413 of the Comprehensive Drug Abuse Prevention and Control Act of 1970 (21 U.S.C. 853(b), (c), and (e)-(o)) shall apply to--

(A) property subject to forfeiture under this subsection;

(B) any seizure or disposition of such property; and

(C) any administrative or judicial proceeding in relation to such property, if not inconsistent with this subsection.

(4) Notwithstanding section 524(c) of title 28, there shall be deposited in the Crime Victims Fund in the Treasury all amounts from the forfeiture of property under this subsection remaining after the payment of expenses for forfeiture and sale authorized by law.

\section{U.S.C. $\$ 794$. Gathering or delivering defense information to aid foreign government}

(a) Whoever, with intent or reason to believe that it is to be used to the injury of the United States or to the advantage of a foreign nation, communicates, delivers, or transmits, or attempts to communicate, deliver, or transmit, to any foreign government, or to any faction or party or military or naval force within a foreign country, whether recognized or unrecognized by the United States, or to any representative, officer, agent, employee, subject, or citizen thereof, either directly or indirectly, any document, writing, code book, signal book, sketch, photograph, photographic negative, blueprint, plan, map, model, note, instrument, appliance, or information relating to the national defense, shall be punished by death or by imprisonment for any term of years or for life, except that the sentence of death shall not be imposed unless the jury or, if there is no jury, the court, further finds that the offense resulted in the identification by a foreign power (as defined in section 101 (a) of the Foreign Intelligence Surveillance Act of 1978 [50 U.S.C. § 1801(a)]) of an individual acting as an agent of the United States and consequently in the death of that individual, or directly concerned nuclear weaponry, military spacecraft or satellites, early warning systems, or other means of defense or retaliation against large-scale attack; war plans; communications intelligence or cryptographic information; or any other major weapons system or major element of defense strategy.

(b) Whoever, in time of war, with intent that the same shall be communicated to the enemy, collects, records, publishes, or communicates, or attempts to elicit any information with respect to the movement, numbers, description, condition, or disposition of any of the Armed Forces, ships, aircraft, or war materials of the United States, or with respect to the plans or conduct, or supposed plans or conduct of any naval or military operations, or with respect to any works or measures undertaken for 
or connected with, or intended for the fortification or defense of any place, or any other information relating to the public defense, which might be useful to the enemy, shall be punished by death or by imprisonment for any term of years or for life.

(c) If two or more persons conspire to violate this section, and one or more of such persons do any act to effect the object of the conspiracy, each of the parties to such conspiracy shall be subject to the punishment provided for the offense which is the object of such conspiracy.

(d)(1) Any person convicted of a violation of this section shall forfeit to the United States irrespective of any provision of State law--

(A) any property constituting, or derived from, any proceeds the person obtained, directly or indirectly, as the result of such violation, and

(B) any of the person's property used, or intended to be used, in any manner or part, to commit, or to facilitate the commission of, such violation.

(2) The court, in imposing sentence on a defendant for a conviction of a violation of this section, shall order that the defendant forfeit to the United States all property described in paragraph (1) of this subsection.

(3) The provisions of subsections (b), (c) and (e) through (o) of section 413 of the Comprehensive Drug Abuse Prevention and Control Act of 1970 (21 U.S.C. 853(b), (c), and (e)-(o)) shall apply to--

(A) property subject to forfeiture under this subsection;

(B) any seizure or disposition of such property; and

(C) any administrative or judicial proceeding in relation to such property, if not inconsistent with this subsection.

(4) Notwithstanding section 524 (c) of title 28, there shall be deposited in the Crime Victims Fund in the Treasury all amounts from the forfeiture of property under this subsection remaining after the payment of expenses for forfeiture and sale authorized by law.

\section{U.S.C. $\$$ 795. Photographing and sketching defense installations}

(a) Whenever, in the interests of national defense, the President defines certain vital military and naval installations or equipment as requiring protection against the general dissemination of information relative thereto, it shall be unlawful to make any photograph, sketch, picture, drawing, map, or graphical representation of such vital military and naval installations or equipment without first obtaining permission of the commanding officer of the military or naval post, camp, or station, or naval vessels, military and naval aircraft, and any separate military or naval command concerned, or higher authority, and promptly submitting the product obtained to such commanding 
officer or higher authority for censorship or such other action as he may deem necessary.

(b) Whoever violates this section shall be fined under this title or imprisoned not more than one year, or both.

\section{U.S.C. $\$ 796$. Use of aircraft for photographing defense installations}

Whoever uses or permits the use of an aircraft or any contrivance used, or designed for navigation or flight in the air, for the purpose of making a photograph, sketch, picture, drawing, map, or graphical representation of vital military or naval installations or equipment, in violation of section $\mathbf{7 9 5}$ of this title, shall be fined under this title or imprisoned not more than one year, or both.

\section{U.S.C. $\$$ 797. Publication and sale of photographs of defense installations}

On and after thirty days from the date upon which the President defines any vital military or naval installation or equipment as being within the category contemplated under section 795 of this title, whoever reproduces, publishes, sells, or gives away any photograph, sketch, picture, drawing, map, or graphical representation of the vital military or naval installations or equipment so defined, without first obtaining permission of the commanding officer of the military or naval post, camp, or station concerned, or higher authority, unless such photograph, sketch, picture, drawing, map, or graphical representation has clearly indicated thereon that it has been censored by the proper military or naval authority, shall be fined under this title or imprisoned not more than one year, or both.

\section{U.S.C. $\$$ 798. Disclosure of classified information}

(a) Whoever knowingly and willfully communicates, furnished, transmits, or otherwise makes available to an unauthorized person, or publishes, or uses in any manner prejudicial to the safety or interest of the United States or for the benefit of any foreign government to the detriment of the United States any classified information--

(1) concerning the nature, preparation, or use of any code, cipher, or cryptographic system of the United States or any foreign government; or

(2) concerning the design, construction, use, maintenance, or repair of any device, apparatus, or appliance used or prepared or planned for use by the United States or any foreign government for cryptographic or communication intelligence purposes; or

(3) concerning the communication intelligence activities of the United States or any foreign government; or

(4) obtained by the processes of communication intelligence from the communications of any foreign government, knowing the same to have been obtained by such processes--

Shall be fined under this title or imprisoned not more than ten years, or both. 
(b) As used in subsection (a) of this section--

The term "classified information" means information which, at the time of a violation of this section, is, for reasons of national security, specifically designated by a United States Government Agency for limited or restricted dissemination or distribution;

The terms "code," "cipher," and "cryptographic system" include in their meanings, in addition to their usual meanings, any method of secret writing and any mechanical or electrical device or method used for the purpose of disguising or concealing the contents, significance, or meanings of communications;

The term "foreign government" includes in its meaning any person or persons acting or purporting to act for or on behalf of any faction, party, department, agency, bureau, or military force of or within a foreign country, or for or on behalf of any government or any person or persons purporting to act as a government within a foreign country, whether or not such government is recognized by the United States;

The term "communication intelligence" means all procedures and methods used in the interception of communications and the obtaining of information from such communications by other than the intended recipients;

The term "unauthorized person" means any person who, or agency which, is not authorized to receive information of the categories set forth in subsection (a) of this section, by the President, or by the head of a department or agency of the United States Government which is expressly designated by the President to engage in communication intelligence activities for the United States.

(c) Nothing in this section shall prohibit the furnishing, upon lawful demand, of information to any regularly constituted committee of the Senate or House of Representatives of the United States of America, or joint committee thereof.

\section{U.S.C. § 798A. Temporary extension of section 794}

The provisions of section 794 of this title [18 U.S.C. $\S 794$ ], as amended and extended by section 1(a)(29) of the Emergency Powers Continuation Act (66 Stat. 333), as further amended by Public Law 12, Eighty-third Congress, in addition to coming into full force and effect in time of war shall remain in full force and effect until six months after the termination of the national emergency proclaimed by the President on December 16, 1950 (Proc. 2912, 3 C.F.R., 1950 Sup., p. 71), or such earlier date as may be prescribed by concurrent resolution of the Congress, and acts which would give rise to legal consequences and penalties under section 794 [18 U.S.C. \$ 794] when performed during a state of war shall give rise to the same legal consequences and penalties when they are performed during the period above provided for. 


\section{EXECUTIVE ORDER 10104.}

\section{DEFINITIONS OF VITAL MILITARY AND NAVAL INSTALLATIONS AND EQUIPMENT}

Source: The provisions of Executive Order 10104 of Feb. 1, 1950, appear at 15 FR 597, 3 CFR, 1949-1953 Comp., p. 298, unless otherwise noted.

WHEREAS section 795 of title 18 of the United States Code provides:

"(a) Whenever, in the interests of national defense, the President defines certain vital military and naval installations or equipment as requiring protection against the general dissemination of information relative thereto, it shall be unlawful to make any photograph, sketch, picture, drawing, map, or graphical representation of such vital military and naval installations or equipment without first obtaining permission of the commanding officer of the military or naval post, camp, or station, or naval vessels, military and naval aircraft, and any separate military or naval command concerned, or higher authority, and promptly submitting the product obtained to such commanding officer or higher authority for censorship or such other action as he may deem necessary.

"(b) Whoever violates this section shall be fined not more than $\$ 1000$ or imprisoned not more than one year, or both.";

AND WHEREAS section 797 of title 18 of the United States Code provides:

"On and after thirty days from the date upon which the President defines any vital military or naval installation or equipment as being within the category contemplated under section 795 of this title, whoever reproduces, publishes, sells, or gives away any photograph, sketch, picture, drawing, map, or graphical representation of the vital military and naval installations or equipment so defined, without first obtaining permission of the commanding officer of the military or naval post, camp, or station concerned, or higher authority, unless such photograph, sketch, picture, drawing, map, or graphical representation has clearly indicated thereon that it has been censored by the proper military or naval authority, shall be fined not more than $\$ 1000$ or imprisoned not more than one year, or both.":

NOW, THEREFORE, by virtue of the authority vested in the me by the foregoing statutory provisions, and in the interests of national defense, 1 hereby define the following as vital military and naval installations or equipment requiring protection against the general dissemination of information relative thereto:

1. All military, naval, or air-force installations and equipment which are now classified, designated, or marked under the authority or at the direction of the President, the Secretary of Defense, the Secretary of the Army, the Secretary of the Navy, or the Secretary of the Air Force as "top secret," "secret," "confidential," or "restricted," and all military, naval, or air-force installations and equipment which may hereafter be so 
classified, designated, or marked with the approval or at the direction of the President, and located within:

(a) Any military, naval, or air-force reservation, post, arsenal, proving ground, range, mine field, camp, base, airfield, fort, yard, station, district, or area.

(b) Any defensive sea area heretofore established by Executive order and not subsequently discounted by Executive order, and any defensive sea area thereafter established under authority of section 2152 of title 18 of the United States Code.

(c) Any airspace reservation heretofore or hereafter established under authority of section 4 of the Air Commerce Act of 1926 (44 Stat. 570; 49 U.S.C. 174) except the airspace reservation established by Executive Order No. 10092 of December $17,1949$.

(d) Any naval harbor closed to foreign vessels

(e) Any area required for fleet purposes

(f) Any commercial establishment engaged in the development or manufacture of classified military or naval arms, munitions, equipment, designs, ships, aircraft, or vessels for the United States Army, Navy, or Air Force.

2. All military, naval, or air-force aircraft, weapons, ammunition, vehicles, ships, vessels, instruments, engines, manufacturing machinery, tools, devices, or any other equipment whatsoever, in the possession of the Army, Navy, Air Force or in the course of experimentation, development, manufacture, or delivery for the Army, Navy, or Air Force which are now classified, designated, or marked under the authority or at the direction of the President, the Secretary of Defense, the Secretary of the Army, the Secretary of the Navy, or the Secretary of the Air Force as "top secret" "secret," "confidential," or "restricted," and all such articles, materials, or equipment which may hereafter be so classified, designated, or marked with the approval or at the direction of the President.

3. All official military, nával, or air-force books, pamphlets, documents, reports, maps, charts, plans, designs, models, drawings photographs, contracts, or specifications which are now marked under the authority or at the direction of the President, the Secretary of Defense, the Secretary of the Army, the Secretary of the Navy, or the Secretary of the Air Force as "top secret" "secret," "confidential," or "restricted," and all such articles, or equipment which may hereafter be so marked with the approval or at the direction of the President.

This order supersedes Executive Order No. 8381 of March 22, 1940, entitled "Defining Certain Vital Military and Naval Installations and Equipment". 
(a) Whoever, being an officer, employee, contractor, or consultant of the United States, and, by virtue of his office, employment, position, or contract, becomes possessed of documents or materials containing classified information of the United States, knowingly removes such documents or materials without authority and with the intent to retain such documents or materials at an unauthorized location shall be fined not more than $\$ 1,000$, or imprisoned for not more than one year, or both.

(b) For purposes of this section, the provision of documents and materials to the Congress shall not constitute an offense under subsection (a).

(c) In this section, the term "classified information of the United States" means information originated, owned, or possessed by the United States Government concerning the national defense or foreign relations of the United States that has been determined pursuant to law or Executive order to require protection against unauthorized disclosure in the interests of national security.

\section{B. SABOTAGE}

\section{U.S.C. § 2151. Definitions}

As used in this chapter [18 U.S.C. §§ 2151 et seq.]:

The words "war material" include arms, armament, ammunition, livestock, forage, forest products and standing timber, stores of clothing, air, water, food, foodstuffs, fuel, supplies, munitions, and all articles, parts or ingredients, intended for, adapted to, or suitable for the use of the United States or any associate nation, in connection with the conduct of war or defense activities.

The words "war premises" include all buildings, grounds, mines, or other places wherein such war material is being produced, manufactured, repaired, stored, mined, extracted, distributed, loaded, unloaded, or transported, together with all machinery and appliances therein contained; and all forts, arsenals, navy yards, camps, prisons, or other installations of the Armed Forces of the United States, or any associate nation.

The words "war utilities" include all railroads, railways, electric lines, roads of whatever description, any railroad or railway fixture, canal, lock, dam, wharf, pier, dock, bridge, building, structure, engine, machine, mechanical contrivance, car, vehicle, boat, aircraft, airfields, air lanes, and fixtures or appurtenances thereof,or any other means of transportation whatsoever, whereon or whereby such war material or any troops of the United States, or of any associate nation, are being or may be transported either within the limits of the United States or upon the high seas or elsewhere; and all air-conditioning systems, dams, reservoirs, aqueducts, water and gas mains and pipes, structures and buildings, whereby or in connection with which air, water or gas is being furnished, or may be furnished, to any war premises or to the Armed Forces of the United States, or any associate nation, and all electric light and power, steam or pneumatic power, telephone and telegraph plants, poles, wires, and fixtures, and wireless 
stations, and the buildings connected with the maintenance and operation thereof used to supply air, water, light, heat, power, or facilities of communication to any war premises or to the Armed Forces of the United States, or any associate nation.

The words "associate nation" mean any nation at war with any nation with which the United States is at war.

The words "national-defense material" include arms, armament, ammunition, livestock, forage, forest products and standing timber, stores of clothing, air, water, food, foodstuff, fuel, supplies, munitions, and all other articles of whatever description and any part or ingredient thereof, intended for, adapted to, or suitable for the use of the United States in connection with the national defense or for use in or in connection with the producing, manufacturing, repairing, storing, mining, extracting, distributing, loading, unloading, or transporting of any of the materials or other articles hereinbefore mentioned or any part or ingredient thereof.

The words "national-defense premises" include all buildings, grounds, mines, or other places wherein such national-defense material is being produced, manufactured, repaired, stored, mined, extracted, distributed, loaded, unloaded, or transported, together with all machinery and appliances therein contained; and all forts, arsenals, navy yards, camps, prisons, or other installations of the Armed Forces of the United States.

The words "national-defense utilities" include all railroads, railways, electric lines, roads of whatever description, railroad or railway fixture, canal, lock, dam, wharf, pier, dock, bridge, building, structure, engine, machine, mechanical contrivance, car, vehicle, boat, aircraft, airfields, air lanes, and fixtures or appurtenances thereof, or any other means of transportation whatsoever, whereon or whereby such national-defense material, or any troops of the United States, are being or may be transported either within the limits of the United States or upon the high seas or elsewhere; and all air-conditioning systems, dams, reservoirs, aqueducts, water and gas mains and pipes, structures, and buildings, whereby or in connection with which air, water, or gas may be furnished to any national-defense premises or to the Armed Forces of the United States, and all electric light and power, steam or pneumatic power, telephone and telegraph plants, poles, wires, and fixtures and wireless stations, and the buildings connected with the maintenance and operation thereof used to supply air, water, light, heat, power, or facilities of communication to any national-defense premises or to the Armed Forces of the United States.

\section{U.S.C. § 2152. Fortifications, harbor defenses, or defensive sea areas}

Whoever willfully trespasses upon, injures, or destroys any of the works or property or material of any submarine mine or torpedo or fortification or harbor-defense system owned or constructed or in process of construction by the United States; or

Whoever willfully interferes with the operation or use of any such submarine mine, torpedo, fortification, or harbor-defense system; or

Whoever knowingly, willfully, or wantonly violates any duly authorized and promulgated order or regulation of the President governing persons or vessels within the limits of defensive sea 
areas, which the President, for purposes of national defense, may from time to time establish by executive order--

Shall be fined under this title or imprisoned not more than five years, or both.

\section{U.S.C. $\$ 2153$. Destruction of war material, war premises, or war utilities}

(a) Whoever, when the United States is at war, or in times of national emergency as declared by the President or by the Congress, with intent to injure, interfere with, or obstruct the United States or any associate nation in preparing for or carrying on the war or defense activities, or, with reason to believe that his act may injure, interfere with, or obstruct the United States or any associate nation in preparing for or carrying on the war or defense activities, willfully injures, destroys, contaminates or infects, or attempts to so injure, destroy, contaminate or infect any war material, war premises, or war utilities, shall be fined under this title or imprisoned not more than thirty years, or both.

(b) If two or more persons conspire to violate this section, and one or more of such persons do any act to effect the object of the conspiracy, each of the parties to such conspiracy shall be punished as provided in subsection (a) of this section.

\section{U.S.C. $\$ 2154$. Production of defective war material, war premises, or war utilities}

(a) Whoever, when the United States is at war, or in times of national emergency as declared by the President or by the Congress, with intent to injure, interfere with, or obstruct the United States or any associate nation in preparing for or carrying on the war or defense activities, or, with reason to believe that his act may injure, interfere with, or obstruct the United States or any associate nation in preparing for or carrying on the war or defense activities, willfully makes, constructs, or causes to be made or constructed in a defective manner, or attempts to make, construct, or cause to be made or constructed in a defective manner any war material, war premises or war utilities, or any tool, implement, machine, utensil, or receptacle used or employed in making, producing, manufacturing, or repairing any such war material, war premises or war utilities, shall be fined under this title or imprisoned not more than thirty years, or both.

(b) If two or more persons conspire to violate this section, and one or more of such persons doany act to effect the object of the conspiracy, each of the parties to such conspiracy shall be punished as provided in subsection (a) of this section.

18 U.S.C. $\$ 2155$. Destruction of national-defense materials, national-defense premises or national-defense utilities

(a) Whoever, with intent to injure, interfere with, or obstruct the national defense of the United States, willfully injures, destroys, contaminates or infects, or attempts to so injure, destroy, contaminate or infect any national-defense material, national-defense 
premises, or national-defense utilities, shall be fined under this title or imprisoned not more than ten years, or both.

(b) If two or more persons conspire to violate this section, and one or more of such persons do any act to effect the object of the conspiracy, each of the parties to such conspiracy shall be punished as provided in subsection (a) of this section.

18 U.S.C. \$ 2156. Production of defective national-defense material, national-defense premises or national-defense utilities

(a) Whoever, with intent to injure, interfere with, or obstruct the national defense of the United States, willfully makes, constructs, or attempts to make or construct in a defective manner, any national-defense material, national-defense premises or nationaldefense utilities, or any tool, implement, machine, utensil, or receptacle used or employed in making, producing, manufacturing, or repairing any such national-defense material, national-defense premises or national-defense utilities, shall be fined under this title or imprisoned not more than ten years, or both.

b) If two or more persons conspire to violate this section, and one or more of such persons do any act to effect the object of the conspiracy, each of the parties to such conspiracy shall be punished as provided in subsection (a) of this section.

18 U.S.C. § 2157. [Repealed]

18 U.S.C. $\$ 2280$. Violence against maritime navigation

(a) Offenses.

(1) In general. A person who unlawfully and intentionally--

(A) seizes or exercises control over a ship by force or threat thereof or any other form of intimidation;

(B) performs an act of violence against a person on board a ship if that act is likely to endanger the safe navigation of that ship;

(C) destroys a ship or causes damage to a ship or to its cargo which is likely to endanger the safe navigation of that ship:

(D) places or causes to be placed on a ship, by any means whatsoever, adevice or substance which is likely to destroy that ship, or cause damage tothat ship or its cargo which endangers or is likely to endanger the safe navigation of that ship;

(E) destroys or seriously damages maritime navigational facilities or seriously interferes with their operation, if such act is likely to endanger the safe navigation of a ship; 
(F) communicates information, knowing the information to be false and under circumstances in which such information may reasonably be believed, thereby endangering the safe navigation of a ship;

(G) injures or kills any person in connection with the commission or the attempted commission of any of the offenses set forth in subparagraphs (A) through (F); or

(H) attempts to do any act prohibited under subparagraphs (A) through (G),

shall be fined under this title, imprisoned not more than 20 years, or both; and if the death of any person results from conduct prohibited by this paragraph, shall be punished by death or imprisoned for any term of years or for life.

(2) Threat to navigation. A person who threatens to do any act prohibited under paragraph (1) (B), (C) or (E), with apparent determination and will to carry the threat into execution, if the threatened act is likely to endanger the safe navigation of the ship in question, shall be fined under this title, imprisoned not more than 5 years, or both.

(b) Jurisdiction. There is jurisdiction over the activity prohibited in subsection (a)--

(1) in the case of a covered ship, if--

(A) such activity is committed--

(i) against or on board a ship flying the flag of the United States at thetime the prohibited activity is committed;

(ii) in the United States and the activity is not prohibited as a crime by the State in which the activity takes place; or

(iii) the activity takes place on a ship flying the flag of a foreign country or outside the United States, by a national of the United States or by a stateless person whose habitual residence is in the United States;

(B) during the commission of such activity, a national of the United States is seized, threatened, injured or killed; or

(C) the offender is later found in the United States after such activity is committed;

(2) in the case of a ship navigating or scheduled to navigate solely within the territorial sea or internal waters of a country other than the United States, if the offender is later found in the United States after such activity is committed; and

(3) in the case of any vessel, if such activity is committed in an attempt to compel the United States to do or abstain from doing any act. 
(c) Bar to prosecution. It is a bar to Federal prosecution under subsection (a) for conduct that occurred within the United States that the conduct involved was during or in relation to a labor dispute, and such conduct is prohibited as a felony under the law of the State in which it was committed. For purposes of this section, the term "labor dispute" has the meaning set forth in section 2(c) of the Norris-LaGuardia Act, as amended (29 U.S.C. 113(c)).

(d) Delivery of suspected offender. The master of a covered ship flying theflag of the United States who has reasonable grounds to believe that there is on board that ship any person who has committed an offense under Article 3 of the Convention for the Suppression of Unlawful Acts Against the Safety of Maritime Navigation may deliver such person to the authorities of a State Party to that Convention. Before delivering such person to the authorities of another country, the master shall notify in an appropriate manner the Attorney General of the United States of the alleged offense and await instructions from the Attorney General as to what action to take. When delivering the person to a country which is a State Party to the Convention, the master shall, whenever practicable, and if possible before entering the territorial sea of such country, notify the authorities of such country of the master's intention to deliver such person and the reasons therefor. If the master delivers such person, the master shall furnish to the authorities of such country the evidence in the master's possession that pertains to the alleged offense.

(e) Definitions. In this section--

"covered ship" means a ship that is navigating or is scheduled to navigate into, through or from waters beyond the outer limit of the territorial sea of a single country or a lateral limit of that country's territorial sea with an adjacent country.

"national of the United States" has the meaning stated in section 101(a)(22) of the Immigration and Nationality Act (8 U.S.C. $1101(\mathrm{a})(22))$.

"territorial sea of the United States" means all waters extending seaward to 12 nautical miles from the baselines of the United States determined in accordance with international law.

"ship" means a vessel of any type whatsoever not permanently attached to the sea-bed, including dynamically supported craft, submersibles or any other floating craft, but does not include a warship, a ship owned or operated by a government when being

used as a naval auxiliary or for customs or police purposes, or a ship which has been withdrawn from navigation or laid up.

"United States", when used in a geographical sense, includes the Commonwealth of Puerto Rico, the Commonwealth of the Northern Mariana Islands and all territories and possessions of the United States. 


\section{U.S.C. $\$$ 33. Destruction of motor vehicles or motor vehicle facilities}

Whoever willfully, with intent to endanger the safety of any person on board or anyone who he believes will board the same, or with a reckless disregard for the safety of human life, damages, disables, destroys, tampers with, or places or causes to be placed any explosive or other destructive substance in, upon, or in proximity to, any motor vehicle which is used, operated, or employed in interstate or foreign commerce, or its cargo or material used or intended to be used in connection with its operation; or

Whoever willfully, with like intent, damages, disables, destroys, sets fire to, tampers with, or places or causes to be placed any explosive or other destructive substance in, upon, or in proximity to any garage, terminal, structure, supply, or facility used in the operation of, or in support of the operation of, motor vehicles engaged in interstate or foreign commerce or otherwise makes or causes such property to be made unworkable, unusable, or hazardous to work or use; or

Whoever, with like intent, willfully disables or incapacitates any driver or person employed in connection with the operation or maintenance of the motor vehicle, or in any way lessens the ability of such person to perform his duties as such; or

Whoever willfully attempts to do any of the aforesaid acts--

shall be fined under this title or imprisoned not more than twenty years, or both.

\section{TREASON AND SUBVERSIVE ACTIVITIES}

\section{U.S.C. § 2381. Treason}

Whoever, owing allegiance to the United States, levies war against them or adheres to their enemies, giving them aid and comfort within the United States or elsewhere, is guilty of treason and shall suffer death, or shall be imprisoned not less than five years and fined under this title but not less than $\$ 10,000$; and shall be incapable of holding any office under the United States.

\section{U.S.C. $\$ 2382$. Misprision of treason}

Whoever, owing allegiance to the United States and having knowledge of the commission of any treason against them, conceals and does not, as soon as may be, disclose and make known the same to the President or to some judge of the United States, or to the governor or to some judge or justice of a particular State, is guilty of misprision of treason and shall be fined under this title or imprisoned not more than seven years, or both.

\section{U.S.C. § 2383. Rebellion or insurrection}

Whoever incites, sets on foot, assists, or engages in any rebellion or insurrection against the authority of the United States or the laws thereof, or gives aid or comfort thereto, shall be 
fined under this title or imprisoned not more than ten years, or both; and shall be incapable of holding any office under the United States.

\section{U.S.C. § 2384. Seditious conspiracy}

If two or more persons in any State or Territory, or in any place subject to the jurisdiction of the United States, conspire to overthrow, put down, or to destroy by force the Government of the United States, or to levy war against them, or to oppose by force the authority thereof, or by force to prevent, hinder, or delay the execution of any law of the United States, or by force to seize, take, or possess any property of the United States contrary to the authority thereof, they shall each be fined under this title or imprisoned not more than twenty years, or both.

\section{U.S.C. $\$ 2385$. Advocating overthrow of Government}

Whoever knowingly or willfully advocates, abets, advises, or teaches the duty, necessity, desirability, or propriety of overthrowing or destroying the government of the United States or the government of any State, Territory, District or Possession thereof, or the government of any political subdivision therein, by force or violence, or by the assassination of any officer of any such government; or

Whoever, with intent to cause the overthrow or destruction of any such government, prints, publishes, edits, issues, circulates, sells, distributes, or publicly displays any written or printed matter advocating, advising, or teaching the duty, necessity, desirability, or propriety of overthrowing or destroying any government in the United States by force or violence, or attempts to do so; or

Whoever organizes or helps or attempts to organize any society, group, or assembly of persons who teach, advocate, or encourage the overthrow or destruction of any such government by force or violence; or becomes or is a member of, or affiliates with, any such society, group, or assembly of persons, knowing the purposes thereof--

Shall be fined under this title or imprisoned not more than twenty years, or both, and shall be ineligible for employment by the United States or any department or agency thereof, for the five years next following his conviction.

If two or more persons conspire to commit any offense named in this section, each shall be fined under this title or imprisoned not more than twenty years, or both, and shall be ineligible for employment by the United States or any department or agency thereof, for the five years next following his conviction.

As used in this section, the terms "organizes" and "organize", with respect to any society, group, or assembly of persons, include the recruiting of new members, the forming of new units, and the regrouping or expansion of existing clubs, classes, and other units of such society, group, or assembly of persons. 


\section{MISREPRESENTATION AND IMPERSONATION}

\section{U.S.C. \$ 499. Military, naval, or official passes}

Whoever falsely makes, forges, counterfeits, alters, or tampers with any naval, military, or official pass or permit, issued by or under the authority of the United States, or with intent to defraud uses or possesses any such pass or permit, or personates or falsely represents himself to be or not to be a person to whom such pass or permit has been duly issued, or willfully allows any other person to have or use any such pass or permit, issued for his use alone, shall be fined under this title or imprisoned not more than five years, or both.

\section{U.S.C. \$ 701. Official badges, identification cards, other insignia}

Whoever manufactures, sells, or possesses any badge, identification card, or other insignia, of the design prescribed by the head of any department or agency of the United States for use by any officer or employee thereof, or any colorable imitation thereof, or photographs, prints, or in any other manner makes or executes any engraving, photograph, print, or impression in the likeness of any such badge, identification card, or other insignia, or any colorable imitation thereof, except as authorized under regulations made pursuant to law, shall be fined under this title or imprisoned not more than six months, or both.

\section{U.S.C. $\$ 872$. Extortion by officers or employees of the United States}

Whoever, being an officer, or employee of the United States or any department or agency thereof, or representing himself to be or assuming to act as such, under color or pretense of office or employment commits or attempts an act of extortion, shall be fined under this title or imprisoned not more than three years, or both; but if the amount so extorted or demanded does not exceed $\$ 100$, he shall be fined under this title or imprisoned not more than one year, or both.

\section{U.S.C. § 880. Receiving the proceeds of extortion}

A person who receives, possesses, conceals, or disposes of any money or other property which was obtained from the commission of any offense under this chapter [18 U.S.C. $\$ \$ 871$ et seq.] that is punishable by imprisonment for more than 1 year, knowing the same to have been unlawfully obtained, shall be imprisoned not more than 3 years, fined under this title, or both.

\section{U.S.C. § 911. Citizen of the United States}

Whoever falsely and willfully represents himself to be a citizen of the United States shall be fined under this title or imprisoned not more than three years, or both. 
Whoever falsely assumes or pretends to be an officer or employee acting under the authority of the United States or any department, agency or officer thereof, and acts as such, or in such pretended character demands or obtains any money, paper, document, or thing of value, shall be fined under this title or imprisoned not more than three years, or both.

\section{U.S.C. § 913. Impersonator making arrest or search}

Whoever falsely represents himself to be an officer, agent, or employee of the United States, and in such assumed character arrests or detains any person or in any manner searches the person, buildings, or other property of any person, shall be fined under this title or imprisoned not more than three years, or both.

\section{U.S.C. \$ 1001. Statements or entries generally}

Whoever, in any matter within the jurisdiction of any department or agency of the United States knowingly and willfully falsifies, conceals or covers up by any trick, scheme, or device a material fact, or makes any false, fictitious or fraudulent statements or representations, or makes or uses any false writing or document knowing the same to contain any false, fictitious or fraudulent statement or entry, shall be fined under this title or imprisoned not more than five years, or both.

\section{U.S.C. \& 1031. Major fraud against the United States}

(a) Whoever knowingly executes, or attempts to execute, any scheme or artifice with the intent--

(1) to defraud the United States; or

(2) to obtain money or property by means of false or fraudulent pretenses, representations, or promises,

in any procurement of property or services as a prime contractor with the United States or as a subcontractor or supplier on a contract in which there is a prime contract with the United States, if the value of the contract, subcontract, or any constituent part thereof, for such property or services is $\$ 1,000,000$ or more shall, subject to the applicability of subsection (c) of this section, be fined not more than $\$$ $1,000,000$, or imprisoned not more than 10 years, or both.

(b) The fine imposed for an offense under this section may exceed the maximum otherwise provided by law, if such fine does not exceed $\$ 5,000,000$ and--

(1) the gross loss to the Government or the gross gain to a defendant is $\$ 500,000$ or greater; or 
(2) the offense involves a conscious or reckless risk of serious personal injury.

(c) The maximum fine imposed upon a defendant for a prosecution including a prosecution with multiple counts under this section shall not exceed $\$ 10,000,000$.

(d) Nothing in this section shall preclude a court from imposing any other sentences available under this title, including without limitation a fine up to twice the amount of the gross loss or gross gain involved in the offense pursuant to 18 U.S.C. section 3571 (d).

(e) In determining the amount of the fine, the court shall consider the factors set forth in 18 U.S.C. sections 3553 and 3572 , and the factors set forth in the guidelines and policy statements of the United States Sentencing Commission, including--

(1) the need to reflect the seriousness of the offense, including the harm or loss to the victim and the gain to the defendant;

(2) whether the defendant previously has been fined for a similar offense; and

(3) any other pertinent equitable considerations.

(f) A prosecution of an offense under this section may be commenced any time not later than 7 years after the offense is committed, plus any additional time otherwise allowed by law.

(g)(1) In special circumstances and in his or her sole discretion, the Attorney General is authorized to make payments from funds appropriated to the Department of Justice to persons who furnish information relating to a possible prosecution under this section. The amount of such payment shall not exceed $\$ 250,000$. Upon application by the Attorney General, the court may order that the Department shall be reimbursed for a payment from a criminal fine imposed under this section.

(2) An individual is not eligible for such a payment if--

(A) that individual is an officer or employee of a Government agency whofurnishes information or renders service in the performance of official duties;

(B) that individual failed to furnish the information to the individual's employer prior to furnishing it to law enforcement authorities, unless the court determines the individual has justifiable reasons for that failure;

(C) the furnished information is based upon public disclosure of allegations or transactions in a criminal, civil, or administrative hearing, in a congressional, administrative, or GAO report, hearing, audit or investigation, or from the news media unless the person is the original source of theinformation. For the purposes of this subsection, "original source" means an individual who has direct and independent knowledge of the information on which the allegations are based and has voluntarily provided the information to the Government; or 
(D) that individual participated in the violation of this section withrespect to which such payment would be made.

(3) The failure of the Attorney General to authorize a payment shall not besubject to judicial review.

(h) Any individual who--

(1) is discharged, demoted, suspended, threatened, harassed, or in any other manner discriminated against in the terms and conditions of employment by anemployer because of lawful acts done by the employee on behalf of the employeeor others in furtherance of a prosecution under this section (including investigation for, initiation of, testimony for, or assistance in such prosecution), and

(2) was not a participant in the unlawful activity that is the subject of said prosecution, may, in a civil action, obtain all relief necessary to make such individual whole. Such relief shall include reinstatement with the sameseniority status such individual would have had but for the discrimination, 2 times the amount of back pay, interest on the back pay, and compensation for any special damages sustained as a result of the discrimination, includinglitigation costs and reasonable attorney's fees.

\section{U.S.C. $\$ 1516$. Obstruction of Federal audit}

(a) Whoever, with intent to deceive or defraud the United States, endeavors to influence, obstruct, or impede a Federal auditor in the performance of official duties relating to a person receiving in excess of $\$ 100,000$, directly or indirectly, from the United States in any 1 year period under a contract or subcontract, shall be fined under this title, or imprisoned not more than 5 years, or both.

(b) For purposes of this section--

(1) the term "Federal auditor" means any person employed on a full- or part-time or contractual basis to perform an audit or a quality assurance inspection for or on behalf of the United States;

(2) the term "in any 1 year period" has the meaning given to the term "in any one-year period" in section 666 .

\section{U.S.C. $\$ 1621$. Perjury generally}

Whoever--

(1) having taken an oath before a competent tribunal, officer, or person, in any case in which a law of the United States authorizes an oath to be administered, that he will testify, declare, depose, or certify truly, or that any written testimony, declaration, 
deposition, or certificate by him subscribed, is true, willfully and contrary to such oath states or subscribes any material matter which he does not believe to be true; or

(2) in any declaration, certificate, verification, or statement under penalty of perjury as permitted under section 1746 of title $\mathbf{2 8}$, United States Code, willfully subscribes as true any material matter which he does not believe to be true; is guilty of perjury and shall, except as otherwise expressly provided by law, be fined under this title or imprisoned not more than five years, or both. This section is applicable whether the statement or subscription is made within or without the United States.

\section{E. EMBEZZLEMENT AND THEFT}

\section{U.S.C. $\$ 21$. Stolen or counterfeit nature of property for certain crimes defined}

(a) Wherever in this title it is an element of an offense that--

(1) any property was embezzled, robbed, stolen, converted, taken, altered, counterfeited, falsely made, forged, or obliterated; and

(2) the defendant knew that the property was of such character;

such element may be established by proof that the defendant, after or as a result of an official representation as to the nature of the property, believed the property to be embezzled, robbed, stolen, converted, taken, altered, counterfeited, falsely made, forged, or obliterated.

(b) For purposes of this section, the term "official representation" means any representation made by a Federal law enforcement officer (as defined in section 115) or by another person at the direction or with the approval of such an officer.

\section{U.S.C. \$ 641. Public money, property or records}

Whoever embezzles, steals, purloins, or knowingly converts to his use or the use of another, or without authority, sells, conveys or disposes of any record, voucher, money, or thing of value of the United States or of any department or agency thereof, or any property made or being made under contract for the United States or any department or agency thereof; or Whoever receives, conceals, or retains the same with intent to convert it to his use or gain, knowing it to have been embezzled, stolen, purloined or converted--

Shall be fined under this title or imprisoned not more than ten years, or both; but if the value of such property does not exceed the sum of $\$ 100$, he shall be fined under this title or imprisoned not more than one year, or both.

The word "value" means face, par, or market value, or cost price, either wholesale or retail, whichever is greater. 
Whoever, being an officer, employee or agent of the United States or of any department or agency thereof, having received public money which he is not authorized to retain as salary, pay, or emolument, fails to render his accounts for the same as provided by law is guilty of embezzlement, and shall be fined under this title or in a sum equal to the amount of the money embezzled, whichever is greater, or imprisoned not more than ten years, or both; but if the amount embezzled does not exceed $\$ 100$, he shall be fined under this title or imprisoned not more than one year, or both.

\section{U.S.C. § 659. Interstate or foreign shipments by carrier; State prosecutions}

Whoever embezzles, steals, or unlawfully takes, carries away, or conceals, or by fraud or deception obtains from any pipeline system, railroad car, wagon, motortruck, or other vehicle, or from any tank or storage facility, station, station house, platform or depot or from any steamboat, vessel, or wharf, or from any aircraft, air terminal, airport, aircraft terminal or air navigation facility with intent to convert to his own use any goods or chattels moving as or which are a part of or which constitute an interstate or foreign shipment of freight, express, or other property; or

Whoever buys or receives or has in his possession any such goods or chattels, knowing the same to have been embezzled or stolen; or

Whoever embezzles, steals, or unlawfully takes, carries away, or by fraud or deception obtains with intent to convert to his own use any baggage which shall have come into the possession of any common carrier for transportation in interstate or foreign commerce or breaks into, steals, takes, carries away, or conceals any of the contents of such baggage, or buys, receives, or has in his possession any such baggage or any article therefrom of whatever nature, knowing the same to have been embezzled or stolen; or

Whoever embezzles, steals, or unlawfully takes by any fraudulent device, scheme, or game, from any railroad car, bus, vehicle, steamboat, vessel, or aircraft operated by any common carrier moving in interstate or foreign commerce or from any passenger thereon any money, baggage, goods, or chattels, or whoever buys, receives, or has in his possession any such money, baggage, goods, or chattels, knowing the same to have been embezzled or stolen--

Shall in each case be fined under this title or imprisoned not more than ten years, or both; but if the amount or value of such money, baggage, goods or chattels does not exceed $\$ 100$, he shall be fined under this title or imprisoned not more than one year, or both.

The offense shall be deemed to have been committed not only in the district where the violation first occurred, but also in any district in which the defendant may have taken or been in possession of the said money, baggage, goods, or chattels.

The carrying or transporting of any such money, freight, express, baggage, goods, or chattels in interstate or foreign commerce, knowing the same to have been stolen, shall constitute a separate offense and subject the offender to the penalties under this section for unlawful taking, and the offense shall be deemed to have been committed in any district into which 
such money, freight, express, baggage, goods, or chattels shall have been removed or into which the same shall have been brought by such offender.

To establish the interstate or foreign commerce character of any shipment in any prosecution under this section the waybill or other shipping document of such shipment shall be prima facie evidence of the place from which and to which such shipment was made. The removal of property from a pipeline system which extends interstate shall be prima facie evidence of the interstate character of the shipment of the property.

A judgment of conviction or acquittal on the merits under the laws of any State shall be a bar to any prosecution under this section for the same act or acts. Nothing contained in this section shall be construed as indicating an intent on the part of Congress to occupy the field in which provisions of this section operate to the exclusion of State laws on the same subject matter, nor shall any provision of this section be construed as invalidating any provision of State law unless such provision is inconsistent with any of the purposes of this section or any provision thereof.

\section{U.S.C. \$ 831. Prohibited transactions involving nuclear materials}

(a) Whoever, if one of the circumstances described in subsection (c) of this section occurs--

(1) without lawful authority, intentionally receives, possesses, uses, transfers, alters, disposes of, or disperses any nuclear material and--

(A) thereby knowingly causes the death of or serious bodily injury to any person or substantial damage to property; or

(B) knows that circumstances exist which are likely to cause the death of or serious bodily injury to any person or substantial damage to property;

(2) with intent to deprive another of nuclear material, knowingly--

(A) takes and carries away nuclear material of another without authority;

(B) makes an unauthorized use, disposition, or transfer, of nuclear material belonging to another; or

(C) uses fraud and thereby obtains nuclear material belonging to another;

(3) knowingly--

(A) uses force; or

(B) threatens or places another in fear that any person other than the actor will imminently be subject to bodily injury; and thereby takes nuclear material belonging to another from the person or presence of any other; 
(4) intentionally intimidates any person and thereby obtains nuclear material belonging to another;

(5) with intent to compel any person, international organization, or governmental entity to do or refrain from doing any act, knowingly threatens to engage in conduct described in paragraph (2)(A) or (3) of this subsection;

(6) knowingly threatens to use nuclear material to cause death or serious bodily injury to any person or substantial damage to property under circumstances in which the threat may reasonably be understood as an expression of serious purposes;

(7) attempts to commit an offense under paragraph (1), (2), (3), or (4) of this subsection; or

(8) is a party to a conspiracy of two or more persons to commit an offense under paragraph (1), (2), (3), or (4) of this subsection, if any of the parties intentionally engages in any conduct in furtherance of such offense; shall be punished as provided in subsection (b) of this section.

(b) The punishment for an offense under--

(1) paragraphs (1) through (7) of subsection (a) of this section is--

(A) a fine under this title; and

(B) imprisonment--

(i) for any term of years or for life (I) if, while committing the offense, the offender knowingly causes the death of any person; or (II) if, while committing an offense under paragraph (1) or (3) of subsection (a) of this section, the offender, under circumstances manifesting extreme indifference to the life of an individual, knowingly engages in any conduct and thereby recklessly causes the death of or serious bodily injury to any person; and

(ii) for not more than 20 years in any other case; and

(2) paragraph (8) of subsection (a) of this section is--

(A) a fine under this title; and

(B) imprisonment--

(i) for not more than 20 years if the offense which is the object of the conspiracy is punishable under paragraph (1)(B)(i); and

(ii) for not more than 10 years in any other case. 
(c) The circumstances referred to in subsection (a) of this section are that--

(1) the offense is committed in the United States or the special maritime and territorial jurisdiction of the United States, or the special aircraft jurisdiction of the United States (as defined in section 46501 of title 49);

(2) the defendant is a national of the United States, as defined in section 101 of the Immigration and Nationality Act (8 U.S.C. 1101);

(3) at the time of the offense the nuclear material is in use, storage, or transport, for peaceful purposes, and after the conduct required for the offense occurs the defendant is found in the United States, even if the conduct required for the offense occurs outside the United States; or

(4) the conduct required for the offense occurs with respect to the carriage of a consignment of nuclear material for peaceful purposes by any means of transportation intended to go beyond the territory of the state where the shipment originates beginning with the departure from a facility of the shipper in that state and ending with the arrival at a facility of the receiver within the state of ultimate destination and either of such states is the United States.

(d) The Attorney General may request assistance from the Secretary of Defense under chapter 18 of title 10 [10 U.S.C. §§ 371 et seq.] in the enforcement of this section and the Secretary of Defense may provide such assistance in accordance with chapter 18 of title 10 [10 U.S.C. \$\$ 371 et seq.], except that the Secretary of Defense may provide such assistance through any Department of Defense personnel.

(e)(1) The Attorney General may also request assistance from the Secretary of Defense under this subsection in the enforcement of this section. Notwithstanding section 1385 of this title, the Secretary of Defense may, in accordance with other applicable law, provide such assistance to the Attorney General if--

(A) an emergency situation exists (as jointly determined by the Attorney General and the Secretary of Defense in their discretion); and

(B) the provision of such assistance will not adversely affect the military preparedness of the United States las determined by the Secretary of Defense in such Secretary's discretion).

(2) As used in this subsection, the term "emergency situation" means a circumstance--

(A) that poses a serious threat to the interests of the United States; and

(B) in which--

(i) enforcement of the law would be seriously impaired if the assistance were not provided; and 
(ii) civilian law enforcement personnel are not capable of enforcing the law.

(3) Assistance under this section may include--

(A) use of personnel of the Department of Defense to arrest persons and conduct searches and seizures with respect to violations of this section; and

(B) such other activity as is incidental to the enforcement of this section, or to the protection of persons or property from conduct that violates this section.

(4) The Secretary of Defense may require reimbursement as a condition of assistance under this section.

(5) The Attorney General may delegate the Attorney General's function under this subsection only to a Deputy, Associate, or Assistant Attorney General.

(f) As used in this section--

(1) the term "nuclear material" means material containing any--

(A) plutonium with an isotopic concentration not in excess of 80 percent plutonium 238;

(B) uranium not in the form of ore or ore residue that contains the mixture of isotopes as occurring in nature;

(C) uranium that contains the isotope 233 or 235 or both in such amount that the abundance ratio of the sum of those isotopes to the isotope 238 is greater than the ratio of the isotope 235 to the isotope 238 occurring in nature; or

(D) uranium 233;

(2) the term "international organization" means a public international organization designated as such pursuant to section 1 of the International Organizations Immunities Act (22 U.S.C. 288 ) or a public organization created pursuant to treaty or other agreement under international law as an instrument through or by which two or more foreign governments engage in some aspect of their conduct of international affairs;

(3) the term "serious bodily injury" means bodily injury which involves--
(A) a substantial risk of death;
(B) extreme physical pain;
(C) protracted and obvious disfigurement; or 
(D) protracted loss or impairment of the function of a bodily member, organ, or mental faculty; and

(4) the term "bodily injury" means--

(A) a cut, abrasion, bruise, burn, or disfigurement;

(B) physical pain;

(C) illness;

(D) impairment of a function of a bodily member, organ, or mental faculty; or

(E) any other injury to the body, no matter how temporary.

\section{U.S.C. $\$ 2111$. Special maritime and territorial jurisdiction}

Whoever, within the special maritime and territorial jurisdiction of the United States, by force and violence, or by intimidation, takes or attempts to take from the person or presence of another anything of value, shall be imprisoned not more than fifteen years.

\section{U.S.C. § 2112. Personal property of United States}

Whoever robs or attempts to rob another of any kind or description of personal property belonging to the United States, shall be imprisoned not more than fifteen years.

\section{U.S.C. $\$ 2114$. Mail, money, or other property of United States}

(a) Assault. A person who assaults any person having lawful charge, control, or custody of any mail matter or of any money or other property of the United States, with intent to rob, steal, or purloin such mail matter, money, or other property of the United States, or robs or attempts to rob any such person of mail matter, or of any money, or other property of the United States, shall, for the first offense, be imprisoned not more than ten years; and if in effecting or attempting to effect such robbery he wounds the person having custody of such mail, money, or other property of the United States, or puts his life in jeopardy by the use of a dangerous weapon, or for a subsequent offense, shall be imprisoned not more than twenty-five years.

(b) Receipt, possession, concealment, or disposal of property. A person who receives, possesses, conceals, or disposes of any money or other property that has been obtained in violation of this section, knowing the same to have been unlawfully obtained, shall be imprisoned not more than 10 years, fined under this title, or both.

\section{U.S.C. $\$ 2117$. Breaking or entering carrier facilities}

Whoever breaks the seal or lock of any railroad car, vessel, aircraft, motortruck, wagon or other vehicle or of any pipeline system, containing interstate or foreign shipments of freight 
or express or other property, or enters any such vehicle or pipeline system with intent in either case to commit larceny therein, shall be fined under this title or imprisoned not more than ten years, or both.

A judgment of conviction or acquittal on the merits under the laws of any State shall be a bar to any prosecution under this section for the same act or acts. Nothing contained in this section shall be construed as indicating an intent on the part of Congress to occupy the field in which provisions of this section operate to the exclusion of State laws on the same subject matter, nor shall any provision of this section be construed as invalidating any provision of State law unless such provision is inconsistent with any of the purposes of this section or any provision thereof.

\section{U.S.C. § 2119. Motor vehicles}

Whoever, with the intent to cause death or serious bodily harm takes a motor vehicle that has been transported, shipped, or received in interstate or foreign commerce from the person or presence of another by force and violence or by intimidation, or attempts to do so, shall--

(1) be fined under this title or imprisoned not more than 15 years, or both,

(2) if serious bodily injury (as defined in section 1365 of this title) results, be fined under this title or imprisoned not more than 25 years, or both, and

if death results, be fined under this title or imprisoned for any number of years up to life, or both, or sentenced to death.

\section{F. MALICIOUS MISCHIEF}

\section{U.S.C. § 1361. Government property or contracts}

Whoever willfully injures or commits any depredation against any property of the United States, or of any department or agency thereof, or any property which has been or is being manufactured or constructed for the United States, or any department or agency thereof, or attempts to commit any of the foregoing offenses shall be punished as follows:

If the damage or attempted damage to such property exceeds the sum of $\$ 100$, by a fine [of] under this title or imprisonment for not more than ten years, or both; if the damage or attempted damage to such property does not exceed the sum of $\$ 100$, by a fine [of] under this title or by imprisonment for not more than one year, or both.

\section{U.S.C. $§ 1362$. Communication lines, stations or systems}

Whoever willfully or maliciously injures or destroys or attempts willfully or maliciously to injure or destroy any of the works, property, or material of any radio, telegraph, telephone or cable, line,station, or system, or other means of communication, operated or controlled by the United States,or used or intended to be used for military or civil defense functions of the United States, whether constructed or in process of construction,or willfully or maliciously interferes in any way with the working or use of any such line,or system,or willfully or maliciously 
obstructs, hinders, or delays the transmission of any communication over any such line, or system, shall be fined under this title or imprisoned not more than ten years, or both.

In the case of any works, property, or material, not operated or controlled by the United States, this section shall not apply to any lawful strike activity, or other lawful concerted activities for the purposes of collective bargaining or other mutual aid and protection which do not injure or destroy any line or system used or intended to be used for the military or civil defense functions of the United States.

\section{U.S.C. \$ 1363. Buildings or property within special maritime and territorial jurisdiction}

Whoever, within the special maritime and territorial jurisdiction of the United States, willfully and maliciously destroys or injures or attempts to destroy or injure any building, structure or vessel, any machinery or building materials and supplies, military or naval stores, munitions of war or any structural aids or applicances for navigation or shipping, shall be fined under this title or imprisoned not more than five years, or both, and if the building be a dwelling, or the life of any person be placed in jeopardy, shall be fined under this title or imprisoned no more than twenty years, or both.

\section{G. CONSPIRACY}

\section{U.S.C. $\$ 371$. Conspiracy to commit offense or to defraud United States}

If two or more persons conspire either to commit any offense against the United States, or to defraud the United States, or any agency thereof in any manner or for any purpose, and one or more of such persons do any act to effect the object of the conspiracy, each shall be fined under this title or imprisoned not more than five years, or both.

If, however, the offense, the commission of which is the object of the conspiracy, is a misdemeanor only, the punishment for such conspiracy shall not exceed the maximum punishment provided for such misdemeanor.

\section{H. SEARCHES AND SEIZURES}

\section{U.S.C. $\$ 111$. Assaulting, resisting, or impeding certain officers or employees}

(a) In general. Whoever--

(1) forcibly assaults, resists, opposes, impedes, intimidates, or interferes with any person designated in section 1114 of this title while engaged in or on account of the performance of official duties; or

(2) forcibly assaults or intimidates any person who formerly served as a person designated in section 1114 on account of the performance of official duties during such person's term of service, shall, where the acts in violation of this section constitute only simple assault, be fined under this title or imprisoned not more than one year, or both, and in 
all other cases, be fined under this title or imprisoned not more than three years, or both.

(b) Enhanced penalty. Whoever, in the commission of any acts described in subsection (a), uses a deadly or dangerous weapon or inflicts bodily injury, shall be fined under this title or imprisoned not more than ten years, or both.

\section{U.S.C. § 2231. Assault or resistance}

(a) Whoever forcibly assaults, resists, opposes, prevents, impedes, intimidates, or interferes with any person authorized to serve or execute search warrants or to make searches and seizures while engaged in the performance of his duties with regard thereto or on account of the performance of such duties, shall be fined under this title or imprisoned not more than three years, or both; and--

(b) Whoever, in committing any act in violation of this section, uses any deadly or dangerous weapon, shall be fined under this title or imprisoned not more than ten years, or both.

\section{U.S.C. $\$ 2232$. Destruction or removal of property to prevent seizure}

(a) Physical interference with search. Whoever, before, during, or after seizure of any property by any person authorized to make searches and seizures, in order to prevent the seizure or securing of any goods, wares, or merchandise by such person, staves, breaks, throws overboard, destroys, or removes the same, shall be fined under this title or imprisoned not more than five years, or both [i].

(b) Notice of search. Whoever, having knowledge that any person authorized to make searches and seizures has been authorized or is otherwise likely to make a search or seizure, in order to prevent the authorized seizing or securing of any person, goods, wares, merchandise or other property, gives notice or attempts to give notice of the possible search or seizure to any person shall be fined under this title or imprisoned not more than five years, or both.

(c) Notice of certain electronic surveillance. Whoever, having knowledge that a Federal investigative or law enforcement officer has been authorized or has applied for authorization under chapter 119 [18 U.S.C. § § 2510 et seq.] to intercept a wire, oral, or electronic communication, in order to obstruct, impede, or prevent such interception, gives notice or attempts to give notice of the possible interception to any person shall be fined under this title or imprisoned not more than five years, or both.

Whoever, having knowledge that a Federal officer has been authorized or has applied for authorization to conduct electronic surveillance under the Foreign Intelligence Surveillance Act of 1978 (50 U.S.C. 1801, et seq.), in order to obstruct, impede, or prevent such activity, gives notice or attempts to give notice of the possible activity to any person shall be fined under this title or imprisoned not more than five years, or both. 
18 U.S.C. $\$ 2233$. Rescue of seized property

Whoever forcibly rescues, dispossesses, or attempts to rescue or dispossess any property, articles, or objects after the same shall have been taken, detained, or seized by any officer or other person under the authority of any revenue law of the United States, or by any person authorized to make searches and seizures, shall be fined under this title or imprisoned not more than two years, or both.

\section{U.S.C. $\$$ 2234. Authority exceeded in executing warrant}

Whoever, in executing a search warrant, willfully exceeds his authority or exercises it with unnecessary severity, shall be fined not more than $\$ 1,000$ or imprisoned not more than one year.

\section{U.S.C. $\$ 2235$. Search warrant procured malicious/y}

Whoever maliciously and without probable cause procures a search warrant to be issued and executed, shall be fined not more than $\$ 1,000$ or imprisoned not more than one year.

\section{U.S.C. 52236. Searches without warrant}

Whoever, being an officer, agent, or employee of the United States or any department or agency thereof, engaged in the enforcement of any law of the United States, searches any private dwelling used and occupied as such dwelling without a warrant directing such search, or maliciously and without reasonable cause searches any other building or property without a search warrant, shall be fined for a first offense not more than $\$ 1,000$; and, for a subsequent offense, shall be fined not more than $\$ 1,000$ or imprisoned not more than one year, or both.

This section shall not apply to any person--

(a) serving a warrant of arrest; or

(b) arresting or attempting to arrest a person committing or attempting to commit an offense in his presence, or who has committed or is suspected on reasonable grounds of having committed a felony; or

(c) making a search at the request or invitation or with the consent of the occupant of the premises.

\section{U.S.C. $\$ 3118$. Implied consent for certain tests}

(a) Consent. Whoever operates a motor vehicle in the special maritime and territorial jurisdiction of the United States consents thereby to a chemical test or tests of such person's blood, breath, or urine, if arrested for any offense arising from such person's driving while under the influence of a drug or alcohol in such jurisdiction. The test or tests shall be administered upon the request of a police officer having reasonable 
grounds to believe the person arrested to have been driving a motor vehicle upon the special maritime and territorial jurisdiction of the United States while under the influence of drugs or alcohol in violation of the laws of a State, territory, possession, or district.

(b) Effect of refusal. Whoever, having consented to a test or tests by reason of subsection (a), refuses to submit to such a test or tests, after having first been advised of the consequences of such a refusal, shall be denied the privilege of operating a motor vehicle upon the special maritime and territorial jurisdiction of the United States during the period of a year commencing on the date of arrest upon which such test or tests was refused, and such refusal may be admitted into evidence in any case arising from such person's driving while under the influence of a drug or alcohol in such jurisdiction. Any person who operates a motor vehicle in the special maritime and territorial jurisdiction of the United States after having been denied such privilege under this subsection shall be treated for the purposes of any civil or criminal proceedings arising out of such operation as operating such vehicle without a license to do so.

\section{U.S.C .\$ 3125. Emergency pen register and trap and trace device installation}

(a) Notwithstanding any other provision of this chapter [18 U.S.C. $\S \S 3121$ et seq.], any investigative or law enforcement officer, specially designated by the Attorney General, the Deputy Attorney General, the Associate Attorney General, any Assistant Attorney General, any acting Assistant Attorney General, or any Deputy Assistant Attorney General, or by the principal prosecuting attorney of any State or subdivision thereof acting pursuant to a statute of that State, who reasonably determines that--

(1) an emergency situation exists that involves--

(A) immediate danger of death or serious bodily injury to any person; or

(B) conspiratorial activities characteristic of organized crime,

that requires the installation and use of a pen register or a trap and trace device before an order authorizing such installation and use can, with due diligence, be obtained, and

(2) there are grounds upon which an order could be entered under this chapter [18 U.S.C. $\S \S 3121$ et seq.] to authorize such installation and use;

may have installed and use a pen register or trap and trace device if, within forty-eight hours after the installation has occurred, or begins to occur, an order approving the installation or use is issued in accordance with section 3123 of this title.["]

(b) In the absence of an authorizing order, such use shall immediately terminate when the information sought is obtained, when the application for the order is denied or when forty-eight hours have lapsed since the installation of the pen register or trap and trace device, whichever is earlier. 
(c) The knowing installation or use by any investigative or law enforcement officer of a pen register or trap and trace device pursuant to subsection (a) without application for the authorizing order within forty-eight hours of the installation shall constitute a violation of this chapter [18 U.S.C. $\$ \S 3121$ et seq.].

(d) A provider of a wire or electronic service, landlord, custodian, or other person who furnished facilities or technical assistance pursuant to this section shall be reasonably compensated for such reasonable expenses incurred in providing such facilities and assistance.

\section{MISCELLANEOUS}

\section{U.S.C. \& 175. Prohibitions with respect to biological weapons}

(a) In general. Whoever knowingly develops, produces, stockpiles, transfers, acquires, retains, or possesses any biological agent, toxin, or delivery system for use as a weapon, or knowingly assists a foreign state or any organization to do so, shall be fined under this title or imprisoned for life or any term of years, or both. There is extraterritorial Federal jurisdiction over an offense under this section committed by or against a national of the United States.

(b) Definition. For purposes of this section, the term "for use as a weapon" does not include the development, production, transfer, acquisition, retention, or possession of any biological agent, toxin, or delivery system for prophylactic, protective, or other peaceful purposes.

18 U.S.C. $\$ 176$. Seizure, forfeiture, and destruction

(a) In general.

(1) Except as provided in paragraph (2), the Attorney General may request the issuance, in the same manner as provided for a search warrant, of a warrant authorizing the seizure of any biological agent, toxin, or delivery system that--

(A) exists by reason of conduct prohibited under section 175 of this title; or

$(B)$ is of a type or in a quantity that under the circumstances has no apparent justification for prophylactic, protective, or other peaceful purposes.

(2) In exigent circumstances, seizure and destruction of any biological agent, toxin, or delivery system described in subparagraphs $(A)$ and $(B)$ of paragraph (1) may be made upon probable cause without the necessity for a warrant.

(b) Procedure. Property seized pursuant to subsection (a) shall be forfeited to the United States after notice to potential claimants and an opportunity for a hearing. At such hearing, the Government shall bear the burden of persuasion by a preponderance of the evidence. Except as inconsistent herewith, the same procedures and provisions of law relating to a forfeiture under the customs laws shall extend to a seizure or forfeiture 
under this section. The Attorney General may provide for the destruction or other appropriate disposition of any biological agent, toxin, or delivery system seized and forfeited pursuant to this section.

(c) Affirmative defense. It is an affirmative defense against a forfeiture under subsection $(a)(1)(B)$ of this section that--

(1) such biological agent, toxin, or delivery system is for a prophylactic, protective, or other peaceful purpose; and

(2) such biological agent, toxin, or delivery system, is of a type and quantity reasonable for that purpose.

\section{U.S.C. § 177. Injunctions}

(a) In general. The United States may obtain in a civil action an injunction against--

(1) the conduct prohibited under section 175 of this title;

(2) the preparation, solicitation, attempt, or conspiracy to engage in onduct prohibited under section 175 of this title; or

(3) the development, production, stockpiling, transferring, acquisition, retention, or possession, or the attempted development, production, stockpiling, transferring, acquisition, retention, or possession of any biological agent, toxin, or delivery system of a type or in a quantity that under the circumstances has no apparent justification for prophylactic, protective, or other peaceful purposes.

(b) Affirmative defense. It is an affirmative defense against an injunction under subsection (a)(3) of this section that--

(1) the conduct sought to be enjoined is for a prophylactic, protective, or other peaceful purpose; and

(2) such biological agent, toxin, or delivery system is of a type and quantity reasonable for that purpose.

\section{U.S.C. $\$ 178$. Definitions (Biological weapons)}

As used in this chapter [18 U.S.C. $\S \S 175$ et seq.]--

(1) the term "biological agent" means any micro-organism, virus, or infectious substance, capable of causing--

(A) death, disease, or other biological malfunction in a human, an animal, a plant, or another living organism; 
(B) deterioration of food, water, equipment, supplies, or material of any kind; or

(C) deleterious alteration of the environment

(2) the term "toxin" means, whatever its origin or method of production--

(A) poisonous substance produced by a living organism; or

(B) any poisonous isomer, homolog, or derivative of such a substance;

(3) the term "delivery system" means--

(A) any apparatus, equipment, device, or means of delivery specifically designed to deliver or disseminate a biological agent, toxin, or vector; or

(B) any vector; and

(4) the term "vector" means a living organism capable of carrying a biological agent or toxin to a host.

\section{U.S.C. $\$ 231$. Civil disorders}

(a)(1) Whoever teaches or demonstrates to any other person the use, application, or making of any firearm or explosive or incendiary device, or technique capable of causing injury or death to persons, knowing or having reason to know or intending that the same will be unlawfully employed for use in, or in furtherance of, a civil disorder which may in any way or degree obstruct, delay, or adversely affect commerce or the movement of any article or commodity in commerce or the conduct or performance of any federally protected function; or

(2) Whoever transports or manufactures for transportation in commerce any firearm, or explosive or incendiary device, knowing or having reason to know or intending that the same will be used unlawfully in furtherance of a civil disorder; or

(3) Whoever commits or attempts to commit any act to obstruct, impede, or interfere with any fireman or law enforcement officer lawfully engaged in the lawful performance of his official duties incident to and during the commission of a civil disorder which in any way or degree obstructs, delays, or adversely affects commerce or the movement of any article or commodity in commerce or the conduct or performance of any federally protected function--

Shall be fined under this title or imprisoned not more than five years, or both.

(b) Nothing contained in this section shall make unlawful any act of any law enforcement officer which is performed in the lawful performance of his official duties. 
As used in this chapter [18 U.S.C. §§ 841 et seq.]--

(a) "Person" means any individual, corporation, company, association, firm, partnership, society, or joint stock company.

(b) "Interstate or foreign commerce" means commerce between any place in a State and any place outside of that State, or within any possession of the United States (not including the Canal Zone) or the District of Columbia, and commerce between places within the same State but through any place outside of that State. "State" includes the District of Columbia, the Commonwealth of Puerto Rico, and the possessions of the United States (not including the Canal Zone).

(c) "Explosive materials" means explosives, blasting agents, and detonators.

(d) Except for the purposes of subsections (d), (e), (f), (g), (h), (i), and (j) of section 844 of this title [18 U.S.C. $\S 844(\mathrm{~d})$-(j)], "explosive" means any chemical compound mixture, or device, the primary or common purpose of which is to function by explosion; the term includes, but is not limited to, dynamite and other high explosives, black powder, pellet powder, initiating explosives, detonators, safety fuses, squibs, detonating cord, igniter cord, and igniters. The Secretary shall publish and revise at least annually in the Federal Register a list of these and any additional explosives which he determines to be within the coverage of this chapter. For the purposes of subsections (d), (e), (f), (g), (h), and (i) of section 844 of this title [18 U.S.C. $\$ 844(\mathrm{~d})-$ (j)], the term "explosive" is defined in subsection (j) of such section 844 [18 U.S.C. $\S 844(\mathrm{j})]$.

(e) "Blasting agent" means any material or mixture, consisting of fuel and oxidizer, intended for blasting, not otherwise defined as an explosive: Provided, That the finished product, as mixed for use or shipment, cannot be detonated by means of a numbered 8 test blasting cap when unconfined.

(f) "Detonator" means any device containing a detonating charge that is used for initiating detonation in an explosive; the term includes, but is not limited to, electric blasting caps of instantaneous and delay types, blasting caps for use with safety fuses and detonating-cord delay connectors.

(g) "Importer" means any person engaged in the business of importing or bringing explosive materials into the United States for purposes of sale or distribution.

(h) "Manufacturer" means any person engaged in the business of manufacturing explosive materials for purposes of sale or distribution or for his own use.

(i) Dealer" means any person engaged in the business of distributing explosive materials at wholesale or retail. 
(j) "Permittee" means any user of explosives for a lawful purpose, who has obtained a user permit under the provisions of this chapter [18 U.S.C. $\S 841$ et seq.].

(k) "Secretary" means the Secretary of the Treasury or his delegate.

(1) "Crime punishable by imprisonment for a term exceeding one year" shall not mean (1) any Federal or State offenses pertaining to antitrust violations, unfair trade practices, restraints of trade, or other similar offenses relating to the regulation of business practices as the Secretary may be regulation designate, or (2) any State offense (other than one involving a firearm or explosive) classified by the laws of the State as a misdemeanor and punishable by a term of imprisonment of two years or less.

(m) "Licensee" means any importer, manufacturer, or dealer licensed under the provisions of this chapter [18 U.S.C. $\S \S 841$ et seq.].

(n) "Distribute" means sell, issue, give, transfer, or otherwise dispose of.

18 U.S.C. $\$$ 844. Penalties (Use of Explosives or Fire)*

(a) Any person who violates subsections (a) through (i) of section 842 of this chapter [18 U.S.C. $\S 842(a)-(i)]$ shall be fined under this title or imprisoned not more than ten years, or both.

(b) Any person who violates any other provision of section 842 of this chapter [18 U.S.C. $\S 842$ ] shall be fined under this title or imprisoned not more than one year, or both.

(c)(1) Any explosive materials involved or used or intended to be used in any violation of the provisions of this chapter or any other rule or regulation promulgated thereunder or any violation of any criminal law of the United States shall be subject to seizure and forfeiture, and all provisions of the Internal Revenue Code of 1954 [26 U.S.C. $\S \S 1$ et seq.] relating to the seizure, forfeiture, and disposition of firearms, as defined in section $5845(a)$ of that Code [26 U.S.C. $\$ 5845(a)$ ], shall, so far as applicable, extend to seizures and forfeitures under the provisions of this chapter [18 U.S.C. $\S \S 841$ et seq.].

(2) Notwithstanding paragraph (1), in the case of the seizure of any explosive materials for any offense for which the materials would be subject to forfeiture in which it would be impracticable or unsafe to remove the materials to a place of storage or would be unsafe to store them, the seizing officer may destroy the explosive materials forthwith. Any destruction under this paragraph shall be in the presence of at least 1 credible witness. The seizing officer shall make a report of the seizure and take samples as the Secretary may by regulation prescribe.

\footnotetext{
'Author's Note: IDCFR 1047.4 (a)(1)(i)(H) limits the authority of a DOE protective force officer to section $(f)$ and $(g)$ of 18 U.S.C. $\$ 844$.
} 
(3) Within 60 days after any destruction made pursuant to paragraph (2), the owner of (including any person having an interest in) the property so destroyed may make application to the Secretary for reimbursement of the value of the property. If the claimant establishes to the satisfaction of the Secretary that--

(A) the property has not been used or involved in a violation of law; or

(B) any unlawful involvement or use of the property was without the claimant's knowledge, consent, or willful blindness, the Secretary shall make an allowance to the claimant not exceeding the value of the property destroyed.

(d) Whoever transports or receives, or attempts to transport or receive, in interstate or foreign commerce any explosive with the knowledge or intent that it will be used to kill, injure, or intimidate any individual or unlawfully to damage or destroy any building, vehicle, or other real or personal property, shall be imprisoned for not more than ten years, or fined under this title, or both; and if personal injury results to any person, including any public safety officer performing duties as a direct or proximate result of conduct prohibited by this subsection, shall be imprisoned for not more than twenty years or fined under this title, or both; and if death results to any person, including any public safety officer performing duties as a direct or proximate result of conduct prohibited by this subsection, shall be subject to imprisonment for any term of years, or to the death penalty or to life imprisonment.

(e) Whoever, through the use of the mail, telephone, telegraph, or other instrument of commerce, willfully makes any threat, or maliciously conveys false information knowing the same to be false, concerning an attempt or alleged attempt being made, or to be made, to kill, injure, or intimidate any individual or unlawfully to damage or destroy any building, vehicle, or other real or personal property by means of fire or an explosive shall be imprisoned for not more than five years or fined under this title, or both.

(f) Whoever maliciously damages, or destroys, or attempts to damage or destroy, by means of fire or an explosive, any building, vehicle, or other personal or real property in whole or in part owned, possessed, or used by, or leased to, the United States, any department or agency thereof, or any institution or organization receiving Federal financial assistance shall be imprisoned for not more than 20 years, fined the greater of the fine under this title or the cost of repairing or replacing any property that is damaged or destroyed, $[$,$] or both; and if personal injury results to any person, including$ any public safety officer performing duties as a direct or proximate result of conduct prohibited by this subsection, shall be imprisoned for not more than 40 years, fined the greater of the fine under this title or the cost of repairing or replacing any property that is damaged or destroyed,[,] or both; and if death results to any person, including any public safety officer performing duties as a direct or proximate result of conduct prohibited by this subsection, shall be subject to imprisonment for any term of years, or to the death penalty or to life imprisonment.

(g)(1) Except as provided in paragraph (2), whoever possesses an explosive in an airport that is subject to the regulatory authority of the Federal Aviation Administration, or in any 
building in whole or in part owned, possessed, or used by, or leased to, the United States or any department or agency thereof, except with the written consent of the agency, department, or other person responsible for the management of such building or airport, shall be imprisoned for not more than five years, or fined under this title, or both.

(2) The provisions of this subsection shall not be applicable to--

(A) the possession of ammunition (as that term is defined in regulations issued pursuant to this chapter [18 U.S.C. $\S \S 841$ et seq.]) in an airport that is subject to the regulatory authority of the Federal Aviation Administration if such ammunition is either in checked baggage or in a closed container; or

(B) the possession of an explosive in an airport if the packaging and transportation of such explosive is exempt from, or subject to and in accordance with, regulations of the Research and Special Projects Administration for the handling of hazardous materials pursuant to chapter 51 of title 49 [49 U.S.C. §§ 5101 et seq.].

(h) Whoever--

(1) uses fire or an explosive to commit any felony which may be prosecuted in a court of the United States, or

(2) carries an explosive during the commission of any felony which may be prosecuted in a court of the United States, including a felony which provides for an enhanced punishment if committed by the use of a deadly or dangerous weapon or device shall, in addition to the punishment provided for such felony, be sentenced to imprisonment for 5 years but not more than 15 years. In the case of a second or subsequent conviction under this subsection, such person shall be sentenced to imprisonment for 10 years but not more than 25 years. Notwithstanding any other provision of law, the court shall not place on probation or suspend the sentence of any person convicted of a violation of this subsection, nor shall the term of imprisonment imposed under this subsection run concurrently with any other term of imprisonment including that imposed for the felony in which the explosive was used or carried.

(i) Whoever maliciously damages or destroys, or attempts to damage or destroy, by means of fire or an explosive, any building, vehicle, or other real or personal property used in interstate or foreign commerce or in any activity affecting interstate or foreign commerce shall be imprisoned for not more than 20 years, fined the greater of the fine under this title or the cost of repairing or replacing any property that is damaged or destroyed,[,] or both; and if personal injury results to any person, including any public safety officer performing duties as a direct or proximate result of conduct prohibited by this subsection, shall be imprisoned for not more than 40 years, fined the greater of the fine under this title or the cost of repairing or replacing any property that is damaged or destroyed[,], or both; and if death results to any person, including any public safety officer performing duties as a direct or proximate result of conduct 
prohibited by this subsection, shall also be subject to imprisonment for any term of years, or to the death penalty or to life imprisonment. No person shall be prosecuted, tried, or punished for any noncapital offense under this subsection unless the indictment is found or the information is instituted within 7 years after the date on which the offense was committed.

For the purposes of subsections (d), (e), (f), (g), (h), and (i) of this section, the term "explosive" means gunpowders, powders used for blasting, all forms of high explosives, blasting materials, fuzes (other than electric circuit breakers), detonators, and other detonating agents, smokeless powders, other explosive or incendiary devices within the meaning of paragraph (5) of section 232 of this title, and any chemical compounds, mechanical mixture, or device that contains any oxidizing and combustible units, or other ingredients, in such proportions, quantities, or packing that ignition by fire, by friction, by concussion, by percussion, or by detonation of the compound, mixture, or device or any part thereof may cause an explosion.

(k) A person who steals any explosives materials which are moving as, or are a part of, or which have moved in, interstate or foreign commerce shall be imprisoned for not more than 10 years, fined under this title, or both.

A person who steals any explosive material from a licensed importer, licensed manufacturer, or licensed dealer, or from any permittee shall be fined under this title, imprisoned not more than 10 years, or both.

(m) A person who conspires to commit an offense under subsection (h) shall be imprisoned for any term of years not exceeding 20 , fined under this title, or both.

\section{U.S.C. § 873. Blackmail}

Whoever, under a threat of informing, or as a consideration for not informing, against any violation of any law of the United States, demands or receives any money or other valuable thing, shall be fined under this title or imprisoned not more than one year, or both.

\section{U.S.C. § 921. Definitions (Firearms)}

(a) As used in this chapter [18 U.S.C. $\$ \S 921$ et seq.]--

(1) The term "person" and the term "whoever" include any individual, corporation, company, association, firm, partnership, society, or joint stock company.

(2) The term "interstate or foreign commerce" includes commerce between any place in a State and any place outside of that State, or within any possession of the United States (not including the Canal Zone) or the District of Columbia, but such term does not include commerce between places within the same State but through any place outside of that State. The term "State" includes the District of Columbia, the Commonwealth of Puerto Rico, and the possessions of the United States (not including the Canal Zone). 
(3) The term "firearm" means (A) any weapon (including a starter gun) which will or is designed to or may readily be converted to expel a projectile by the action of an explosive; (B) the frame or receiver of any such weapon; (C) any firearm muffler or firearm silencer; or (D) any destructive device. Such term does not include an antique firearm.

(4) The term "destructive device" means--

(A) any explosive, incendiary, or poison gas--

(i) bomb,

(ii) grenade,

(iii) rocket having a propellant charge of more than four ounces,

(iv) missile having an explosive or incendiary charge of more than one-quarter ounce,

(v) mine, or

(vi) device similar to any of the devices described in the preceding clauses;

(B) any type of weapon (other than a shotgun or a shotgun shell which the Secretary finds is generally recognized as particularly suitable for sporting purposes) by whatever name known which will, or which may be readily converted to, expel a projectile by the action of an explosive or other propellant, and which has any barrel with a bore of more than one-half inch in diameter; and

(C) any combination of parts either designed or intended for use in converting any device into any destructive device described in subparagraph $(A)$ or $(B)$ and from which a destructive device may be readily assembled.

The term "destructive device" shall not include any device which is neither designed nor redesigned for use as a weapon; any device, although originally designed for use as a weapon, which is redesigned for use as a signaling. pyrotechnic, line throwing, safety, or similar device; surplus ordinance sold, loaned, or given by the Secretary of the Army pursuant to the provisions of section $4684(2), 4685$, or 4686 of title 10 [10 U.S.C. $\$ \S 4684(2), 4685$, or 46861; or any other device which the Secretary of the Treasury finds is not likely to be used as a weapon, is an antique, or is a rifle which the owner intends to use solely for sporting, recreational or cultural purposes.

(5) The term "shotgun" means a weapon designed or redesigned, made or remade, and intended to be fired from the shoulder and designed or redesigned and made or remade to use the energy of the explosive in a fixed shotgun shell to fire through a smooth bore either a number of ball shot or a single projectile for each single pull of the trigger. 
(6) The term "short-barreled shotgun" means a shotgun having one or more barrels less than eighteen inches in length and any weapon made from a shotgun (whether by alteration, modification, or otherwise) if such weapon as modified has an overall length of less than twenty-six inches.

(7) The term "rifle" means a weapon designed or redesigned, made or remade, and intended to be fired from the shoulder and designed or redesigned and made or remade to use the energy of the explosive in a fixed metallic cartridge to fire only a single projectile through a rifled bore for each single pull of the trigger.

(8) The term "short-barreled rifle" means a rifle having one or more barrels less than sixteen inches in length and any weapon made from a rifle (whether by alteration, modification, or otherwise) if such weapon, as modified, has an overall length of less than twenty-six inches.

(9) The term "importer" means any person engaged in the business of importing or bringing firearms or ammunition into the United States for purposes of sale or distribution; and the term "licensed importer" means any such person licensed under the provisions of this chapter [18 U.S.C. $\$ \S 921$ et seq.].

(10) The term "manufacturer" means any person engaged in the business of manufacturing firearms or ammunition for purposes of sale or distribution; and the term "licensed manufacturer" means any such person licensed under the provisions of this chapter [18 U.S.C. $\S \S 921$ et seq.].

(11) The term "dealer" means (A) any person engaged in the business of selling firearms at wholesale or retail, (B) any person engaged in the business of repairing firearms or of making or fitting special barrels, stocks, or trigger mechanisms to firearms, or (C) any person who is a pawnbroker. The term "licensed dealer" means any dealer who is licensed under the provisions of this chapter [18 U.S.C. $\S \S 921$ et seq].

(12) The term "pawnbroker" means any person whose business or occupation includes the taking or receiving, by way of pledge or pawn, of any firearm as security for the payment or repayment of money.

(13) The term "collector" means any person who acquires, holds, or disposes of firearms as curios or relics, as the Secretary shall by regulation define, and the term "licensed collector" means any such person licensed under the provisions of this chapter [18 U.S.C. $\S \S 921$ et seq.].

(14) The term "indictment" includes an indictment or information in any court under which a crime punishable by imprisonment for a term exceeding one year may be prosecuted.

(15) The term "fugitive from justice" means any person who has fled from any State to avoid prosecution for a crime or to avoid giving testimony in any criminal proceeding. 
(A) any firearm (including any firearm with a matchlock, flintlock, percussion cap, or similar type of ignition system) manufactured in or before 1898; and

(B) any replica of any firearm described in subparagraph (A) if such replica--

(i) is not designed or redesigned for using rimfire or conventional centerfire fixed ammunition, or

(ii) uses rimfire or conventional centerfire fixed ammunition which is no longer manufactured in the United States and which is not readily available in the ordinary channels of commercial trade.

(17) (A) The term "ammunition" means ammunition or cartridge cases, primers, bullets, or propellant powder designed for use in any firearm.

(B) The term "armor piercing ammunition" means--

(i) a projectile or projectile core which may be used in a handgun and which is constructed entirely (excluding the presence of traces of other substances) from one or a combination of tungsten alloys, steel, iron, brass, bronze, beryllium copper, or depleted uranium; or

(ii) a full jacketed projectile larger than .22 caliber designed and intended for use in a handgun and whose jacket has a weight of more than 25 percent of the total weight of the projectile.

(C) The term "armor piercing ammunition" does not include shotgun shot required by Federal or State environmental or game regulations for hunting purposes, a frangible projectile designed for target shooting, a projectile which the Secretary finds is primarily intended to be used for sporting purposes, or any other projectile or projectile core which the Secretary finds is intended to be used for industrial purposes, including a charge used in an oil and gas well perforating device.

(18) The term "Secretary" or "Secretary of the Treasury" means the Secretary of the Treasury or his delegate.

(19) The term "published ordinance" means a published law of any political subdivision of a State which the Secretary determines to be relevant to the enforcement of this chapter [18 U.S.C. $\S \S 921$ et seq.] and which is contained on a list compiled by the Secretary, which list shall be published in the Federal Register, revised annually, and furnished to each licensee under this chapter [18 U.S.C. $\S \S 921$ et seq.]. 
(20) The term "crime punishable by imprisonment for a term exceeding one year" does not include--

(A) any Federal or State offenses pertaining to antitrust violations, unfair trade practices, restraints of trade, or other similar offenses relating to the regulation of business practices, or

(B) any State offense classified by the laws of the State as a misdemeanor and punishable by a term of imprisonment of two years or less.

What constitutes a conviction of such a crime shall be determined in accordance with the law of the jurisdiction in which the proceedings were held. Any conviction which has been expunged, or set aside or for which a person has been pardoned or has had civil rights restored shall not be considered a conviction for purposes of this chapter, unless such pardon, expungement, or restoration of civil rights expressly provides that the person may not ship, transport, possess, or receive firearms.

(21) The term "engaged in the business" means--

(A) as applied to a manufacturer of firearms, a person who devotes time, attention, and labor to manufacturing firearms as a regular course of trade or business with the principal objective of livelihood and profit through the sale or distribution of the firearms manufactured;

(B) as applied to a manufacturer of ammunition, a person who devotes time, attention, and labor to manufacturing ammunition as a regular course of trade or business with the principal objective of livelihood and profit through the sale or distribution of the ammunition manufactured;

(C) as applied to a dealer in firearms, as defined in section $921(a)(11)(A)$ [subsec. (a)(11)(A) of this sectionl, a person who devotes time, attention, and labor to dealing in firearms as a regular course of trade or business with the principal objective of livelihood and profit through the repetitive purchase and resale of firearms, but such term shall not include a person who makes occasional sales, exchanges, or purchases of firearms for the enhancement of a personal collection or for a hobby, or who sells all or part of his personal collection of firearms;

(D) as applied to a dealer in firearms, as defined in section 921 (a)(11)(B) [subsec. (a)(11)(B) of this sectionl, a person who devotes time, attention, and labor to engaging in such activity as a regular course of trade or business with the principal objective of livelihood and profit, but such term shall not include a person who makes occasional repairs of firearms, or who occasionally fits special barrels, stocks, or trigger mechanisms to firearms;

(E) as applied to an importer of firearms, a person who devotes time, attention, and labor to importing firearms as a regular course of trade or business with the 
principal objective of livelihood and profit through the sale or distribution of the firearms imported; and

(F) as applied to an importer of ammunition, a person who devotes time, attention, and labor to importing ammunition as a regular course of trade or business with the principal objective of livelihood and profit through the sale or distribution of the ammunition imported.

(22) The term "with the principal objective of livelihood and profit" means that the intent underlying the sale or disposition of firearms is predominantly one of obtaining livelihood and pecuniary gain, as opposed to other intents, such as improving or liquidating a personal firearms collection: Provided, That proof of profit shall not be required as to a person who engages in the regular and repetitive purchase and disposition of firearms for criminal purposes or terrorism. For purposes of this paragraph, the term "terrorism" means activity, directed against United States persons, which--

(A) is committed by an individual who is not a national or permanent resident alien of the United States;

(B) involves violent acts or acts dangerous to human life which would be a criminal violation if committed within the jurisdiction of the United States; and

(C) is intended--

(i) to intimidate or coerce a civilian population;

(ii) to influence the policy of a government by intimidation or coercion; or

(iii) to affect the conduct of a government by assassination or kidnapping.

(23) The term "machinegun" has the meaning given such term in section $5845(b)$ of the National Firearms Act (26 U.S.C. 5845(b)).

(24) The terms "firearm silencer" and "firearm muffler" mean any device for silencing, muffling, or diminishing the report of a portable firearm, including any combination of parts, designed or redesigned, and intended for use in assembling or fabricating a firearm silencer or firearm muffler, and any part intended only for use in such assembly or fabrication.

(25) The term "school zone" means--

(A) in, or on the grounds of, a public, parochial or private school; or

(B) within a distance of 1,000 feet from the grounds of a public, parochial or private school. 
(26) The term "school" means a school which provides elementary or secondary education, as determined under State law.

(27) The term "motor vehicle" has the meaning given such term in section 10102 of title 49, United States Code.

(28) The term "semiautomatic rifle" means any repeating rifle which utilizes a portion of the energy of a firing cartridge to extract the fired cartridge case and chamber the next round, and which requires a separate pull of the trigger to fire each cartridge.

(29) The term "handgun" means--

(A) a firearm which has a short stock and is designed to be held and fired by the use of a single hand; and

(B) any combination of parts from which a firearm described in subparagraph (A) can be assembled.

(30) The term "semiautomatic assault weapon" means--

(A) any of the firearms, or copies or duplicates of the firearms in any caliber, known as--

(i) Norinco, Mitchell, and Poly Technologies Avtomat Kalashnikovs (all models);

(ii) Action Arms Israeli Military Industries UZI and Galil;

(iii) Beretta Ar70 (SC-70);

(iv) Colt AR-15;

(v) Fabrique National FN/FAL, FN/LAR, and FNC;

(vi) SWD $M-10, M-11, M-11 / 9$, and $M-12$;

(vii) Steyr AUG

(viii) INTRATEC TEC-9, TEC-DC9 and TEC-22; and

(ix) revolving cylinder shotguns, such as (or similar to) the Street Sweeper and Striker 12;

(B) a semiautomatic rifle that has an ability to accept a detachable magazine and has at least 2 of--

(i) a folding or telescoping stock; 
(ii) a pistol grip that protrudes conspicuously beneath the action of the weapon;

(iii) a bayonet mount;

(iv) a flash suppressor or threaded barrel designed to accommodate a flash suppressor; and

(v) . a grenade launcher;

(C) a semiautomatic pistol that has an ability to accept a detachable magazine and has at least 2 of--

(i) an ammunition magazine that attaches to the pistol outside of the pistol grip;

(ii) a threaded barrel capable of accepting a barrel extender, flash suppressor, forward handgrip, or silencer;

(iii) a shroud that is attached to, or partially or completely encircles, the barrel and that permits the shooter to hold the firearm with the nontrigger hand without being burned;

(iv) a manufactured weight of 50 ounces or more when the pistol is unloaded; and

(v) a semiautomatic version of an automatic firearm; and

(D) a semiautomatic shotgun that has at least 2 of--

(i) a folding or telescoping stock;

(ii) a pistol grip that protrudes conspicuously beneath the action of the weapon;

(iii) a fixed magazine capacity in excess of 5 rounds; and

(iv) an ability to accept a detachable magazine.

(31) The term "large capacity ammunition feeding device"--

(A) means a magazine, belt, drum, feed strip, or similar device manufactured after the date of enactment of the Violent Crime Control and Law Enforcement Act of 1994

[enacted Sept. 13, 1994] that has a capacity of, or that can be readily restored or converted to accept, more than 10 rounds of ammunition; but

(B) does not include an attached tubular device designed to accept, and capable of operating only with, .22 caliber rimfire ammunition. 
(32) The term "intimate partner" means, with respect to a person, the spouse of the person, a former spouse of the person, an individual who is a parent of a child of the person, and an individual who cohabitates or has cohabited with the person.

(b) For the purposes of this chapter [18 U.S.C. $\S \S 921$ et seq], a member of the Armed Forces on active duty is a resident of the State in which his permanent duty station is located.

\section{U.S.C. $\$ 927$. Effect on State law (Firearms)}

No provision of this chapter [18 U.S.C. $\S \S 921$ et seq.] shall be construed as indicating an intent on the part of the Congress to occupy the field in which such provision operates to the exclusion of the law of any State on the same subject matter, unless there is a direct and positive conflict between such provision and the law of the State so that the two cannot be reconciled or consistently stand together.

\section{U.S.C. $\$ 930$. Possession of firearms and dangerous weapons in Federal facilities}

(a) Except as provided in subsection (d), whoever knowingly possesses or causes to be present a firearm or other dangerous weapon in a Federal facility lother than a Federal court facility), or attempts to do so, shall be fined under this title or imprisoned not more than 1 year, or both.

(b) Whoever, with intent that a firearm or other dangerous weapon be used in the commission of a crime, knowingly possesses or causes to be present such firearm or dangerous weapon in a Federal facility, or attempts to do so, shall be fined under this title or imprisoned not more than 5 years, or both.

(c) A person who kills or attempts to kill any person in the course of aviolation of subsection (a) or (b), or in the course of an attack on a Federal facility involving the use of a firearm or other dangerous weapon, shall be punished as provided in sections 1111,1112 , and 1113.

(d) Subsection (a) shall not apply to--

(1) the lawful performance of official duties by an officer, agent, or employee of the United States, a State, or a political subdivision thereof, who is authorized by law to engage in or supervise the prevention, detection, investigation, or prosecution of any violation of law;

(2) the possession of a firearm or other dangerous weapon by a Federal official or a member of the Armed Forces if such possession is authorized by law; or

(3) the lawful carrying of firearms or other dangerous weapons in a Federal facility incident to hunting or other lawful purposes. 
(e)(1) Except as provided in paragraph (2), whoever knowingly possesses or causes to be present a firearm in a Federal court facility, or attempts to do so, shall be fined under this title, imprisoned not more than 2 years, or both.

(2) Paragraph (1) shall not apply to conduct which is described in paragraph (1) or (2) of subsection [(d)] (c).

(f) Nothing in this section limits the power of a court of the United States to punish for contempt or to promulgate rules or orders regulating, restricting, or prohibiting the possession of weapons within any building housing such court or any of its proceedings, or upon any grounds appurtenant to such building.

(g) As used in this section:

(1) The term "Federal facility" means a building or part thereof owned or leased by the Federal Government, where Federal employees are regularly presentfor the purpose of performing their official duties.

(2) The term "dangerous weapon" means a weapon, device, instrument, material, or substance, animate or inanimate, that is used for, or is readily capable of, causing death or serious bodily injury, except that such term does not include a pocket knife with a blade of less than $21 / 2$ inches in length.

(3) The term "Federal court facility" means the courtroom, judges' chambers, witness rooms, jury deliberation rooms, attorney conference rooms, prisoner holding cells, offices of the court clerks, the United States attorney, and the United States marshal, probation and parole offices, and adjoining corridors of any court of the United States.

$[(h)](g)$ Notice of the provisions of subsections (a) and (b) shall be posted conspicuously at each public entrance to each Federal facility, and notice of subsection [(e)](d) shall be posted conspicuously at each public entrance to each Federal court facility, and no person shall be convicted of an offense under subsection (a) or [(e)](d) with respect to a Federal facility if such notice is not so posted at such facility, unless such person had actual notice of subsection (a) or $[(e)](d)$, as the case may be.

\section{U.S.C. $\$ 1111$. Murder}

(a) Murder is the unlawful killing of a human being with malice aforethought. Every murder perpetrated by poison, lying in wait, or any other kind of willful, deliberate, malicious, and premeditated killing; or committed in the perpetration of, or attempt to perpetrate, any arson, escape, murder, kidnaping, treason, espionage, sabotage, aggravated sexual abuse or sexual abuse burglary, or robbery; or perpetrated from a premeditated design unlawfully and maliciously to effect the death of any human being other than him who is killed, is murder in the first degree.

Any other murder is murder in the second degree. 
(b) Within the special maritime and territorial jurisdiction of the United States,

Whoever is guilty of murder in the first degree shall be punished by death or by imprisonment for life;

Whoever is guilty of murder in the second degree, shall be imprisoned for any term of years or for life.

\section{U.S.C. \$ 1112. Manslaughter}

(a) Manslaughter is the unlawful killing of a human being without malice. It is of two kinds:

Voluntary-Upon a sudden quarrel or heat of passion.

Involuntary--in the commission of an unlawful act not amounting to a felony, or in the commission in an unlawful manner, or without due caution and circumspection, of a lawful act which might produce death.

(b) Within the special maritime and territorial jurisdiction of the United States,

Whoever is guilty of voluntary manslaughter, shall be fined under this title or imprisoned not more than ten years, or both;

Whoever is guilty of involuntary manslaughter, shall be fined under this title or imprisoned not more than six years, or both.

18 USCS $\$$ 1121. Killing persons aiding Federal investigations or State correctional officers

(a) Whoever intentionally kills--

(1) a State or local official, law enforcement officer, or other officer or employee while working with Federal law enforcement officials in furtherance of a Federal criminal investigation--

(A) while the victim is engaged in the performance of official duties;

(B) because of the performance of the victim's official duties; or

(C) because of the victim's status as a public servant; or

(2) any person assisting a Federal criminal investigation, while that assistance is being rendered and because of it,

shall be sentenced according to the terms of section 1111 , including by sentence of death or by imprisonment for life. 
(b)(1) Whoever, in a circumstance described in paragraph (3) of this subsection, while incarcerated, intentionally kills any State correctional officer engaged in, or on account of the performance of such officer's official duties, shall be sentenced to a term of imprisonment which shall not be lessthan 20 years, and may be sentenced to life imprisonment or death.

(2) As used in this section, the term, "State correctional officer" includes any officer or employee of any prison, jail, or other detention facility, operated by, or under contract to, either a State or local governmental agency, whose job responsibilities include providing for the custody of incarcerated individuals.

(3) The circumstance referred to in paragraph (1) is that--

(A) the correctional officer is engaged in transporting the incarcerated person interstate; or

(B) the incarcerated person is incarcerated pursuant to a conviction for anoffense against the United States.

\section{U.S.C. $\$$ 1382. Entering military, naval, or Coast Guard property}

Whoever, within the jurisdiction of the United States, goes upon any military, naval, or Coast Guard reservation, post, fort, arsenal, yard, station, or installation, for any purpose prohibited by law or lawful regulation; or

Whoever reenters or is found within any such reservation, post, fort, arsenal, yard, station, or installation, after having been removed therefrom or ordered not to reenter by any officer or person in command or charge thereof--

Shall be fined under this title or imprisoned not more than six months, or both.

\section{U.S.C. § 1383. [Repealed]}

\section{U.S.C. $\$ 1864$. Hazardous or injurious devices on Federal lands}

(a) Whoever--

(1) with the intent to violate the Controlled Substances Act,

(2) with the intent to obstruct or harass the harvesting of timber, or

(3) with reckless disregard to the risk that another person will be placed indanger of death or bodily injury and under circumstances manifesting extreme indifference to such risk, uses a hazardous or injurious device on Federal land, on an Indian reservation, or on an Indian allotment while the title to such allotment is held in trust by the United States or while such allotment remains inalienable by the allottee without the consent of the United States shall be punished under subsection (b). 
(b) An individual who violates subsection (a) shall--

(1) if death of an individual results, be fined under this title or imprisoned for any term of years or for life, or both;

(2) if serious bodily injury to any individual results, be fined under this title or imprisoned for not more than twenty years, or both;

(3) if bodily injury to any individual results, be fined under this title or imprisoned for not more than ten years, or both;

(4) if damage exceeding $\$ 10,000$ to the property of any individual results, be fined under this title or imprisoned for not more than ten years, or both; and

(5) in any other case, be fined under this title or imprisoned for not more than one year.

(c) Any individual who is punished under subsection (b)(5) after one or more prior convictions under any such subsection shall be fined under this title or imprisoned for not more than ten years, or both.

(d) As used in this section--

(1) the term "serious bodily injury" means bodily injury which involves--
(A) a substantial risk of death;
(B) extreme physical pain;
(C) protracted and obvious disfigurement; and
(D) protracted loss or impairment of the function of bodily member, organ, or mental faculty;

(2) the term "bodily injury" means--
(A) a cut, abrasion, bruise, burn, or disfigurement;
(B) physical pain;
(C) illness;
(D) impairment of the function of a bodily member, organ, or mental faculty; or
(E) any other injury to the body, no matter how temporary; and 
(3) the term "hazardous or injurious device" means a device, which when assembled or placed, is capable of causing bodily injury, or damage to property, by the action of any person making contact with such device subsequent to the assembly or placement. Such term includes guns attached to trip wires or other triggering mechanisms, ammunition attached to trip wires or other triggering mechanisms, or explosive devices attached to trip wires or other triggering mechanisms, sharpened stakes, lines or wires, lines or wires with hooks attached, nails placed so that the sharpened ends are positioned in an upright manner, or tree spiking devices including spikes, nails, or other objects hammered, driven, fastened, or otherwise placed into or on any timber, whether or not severed from the stump.

\section{U.S.C. $\$ 2071$. Concealment, removal, or mutilation generally}

(a) Whoever willfully and unlawfully conceals, removes, mutilates, obliterates, or destroys, or attempts to do so, or, with intent to do so takes and carries away any record, proceeding, map, book, paper, document, or other thing, filed or deposited with any clerk or officer of any court of the United States, or in any public office, or with any judicial or public officer of the United States, shall be fined under this title or imprisoned not more than three years, or both.

(b) Whoever, having the custody of any such record, proceeding, map, book, document, paper, or other thing, willfully and unlawfully conceals, removes, mutilates, obliterates, falsifies, or destroys the same, shall be fined under this title or imprisoned not more than three years, or both; and shall forfeit his office and be disqualified from holding any office under the United States. As used in this subsection, the term "office" does not include the office held by any person as a retired officer of the Armed Forces of the United States.

\section{U.S.C. $\$ 2331$. Definitions (Terrorism)}

As used in this chapter [18 U.S.C. $\S 2331$ et seq.] --

(1) the term "international terrorism" means activities that--

(A) involve violent acts or acts dangerous to human life that are a violation of the criminal laws of the United States or of any State, or that would be a criminal violation if committed within the jurisdiction of the United States or of any State;

(B) appear to be intended--

(i) to intimidate or coerce a civilian population;

(ii) to influence the policy of a government by intimidation or coercion; or

(iii) to affect the conduct of a government by assassination or kidnapping; and 
(C) occur primarily outside the territorial jurisdiction of the United States, or transcend national boundaries in terms of the means by which they are accomplished, the persons they appear intended to intimidate or coerce, or the locale in which their perpetrators operate or seek asylum;

(2) the term "national of the United States" has the meaning given such term in section $101(a)(22)$ of the Immigration and Nationality Act [8 U.S.C. \$1101(a)(22)];

(3) the term "person" means any individual or entity capable of holding a legal or beneficial interest in property; and

(4) the term "act of war" means any act occurring in the course of--
(A) declared war;
(B) armed conflict, whether or not war has been declared, between two or more nations; or
(C) armed conflict between military forces of any origin.

18 U.S.C. $\$ 2332 a$. Use of weapons of mass destruction

(a) Offense. A person who uses, or attempts or conspires to use, a weapon of mass destruction--

(1) against a national of the United States while such national is outside of the United States;

(2) against any person within the United States; or

(3) against any property that is owned, leased or used by the United States or by any department or agency of the United States, whether the property is within or outside of the United States,

shall be imprisoned for any term of years or for life, and if death results, shall be punished by death or imprisoned for any term of years or for life.

(b) Definitions. For purposes of this section--

(1) the term "national of the United States" has the meaning given in section 101(a)(22) of the Immigration and Nationality Act (8 U.S.C. § 1101(a)(22)); and

(2) the term "weapon of mass destruction" means--

(A) any destructive device as defined in section 921 of this title; 
(B) poison gas;

(C) any weapon involving a disease organism; or

(D) any weapon that is designed to release radiation or radioactivity at a level dangerous to human life.

\section{U.S.C. $\$$ 2338. Exclusive Federal jurisdiction}

The district courts of the United States shall have exclusive jurisdiction over an action brought under this chapter [18 U.S.C. $\S \S 2331$ et seq.].

\section{U.S.C. $\$ 2339$ A. Providing material support to terrorists}

(a) Definition. In this section, "material support or resources" means currency or other financial securities, financial services, lodging, training, safehouses, false documentation or identification, communications equipment, facilities, weapons, lethal substances, explosives, personnel, transportation, and other physical assets, but does not include humanitarian assistance to persons not directly involved in such violations.

(b) Offense. A person who, within the United States, provides material support or resources or conceals or disguises the nature, location, source, or ownership of material support or resources, knowing or intending that they are to be used in preparation for, or in carrying out, a violation of section $32,36,351,844$ (f) or (i), $1114,1116,1203,1361,1363,1751,2280,2281,2331$, or 2339 of this title or section 46502 of title 49 , or in preparation for or carrying out the concealment of an escape from the

commission of any such violation, shall be fined under this title, imprisoned not more than 10 years, or both.

(c) Investigations.

(1) In general. Within the United States, an investigation may be initiated or continued under this section only when facts reasonably indicate that--

(A) in the case of an individual, the individual knowingly or intentionally engages, has engaged, or is about to engage in the violation of this or any other Federal criminal law; and

(B) in the case of a group of individuals, the group knowingly or intentionally engages, has engaged, or is about to engage in the violation of this or any other Federal criminal law.

(2) Activities protected by the First Amendment. An investigation may not be initiated or continued under this section based on activities protected by the First Amendment to the Constitution, including expressions of support or the provision of financial support 
for the nonviolent political, religious, philosophical, or ideological goals or beliefs of any person or group.

\section{U.S.C. $\$ 3281$. Capital offenses}

An indictment for any offense punishable by death may be found at any time without limitation.

\section{U.S.C. $\$ 3282$. Offenses not capital}

Except as otherwise expressly provided by law, no person shall be prosecuted, tried, or punished for any offense, not capital, unless the indictment is found or the information is instituted within five years next after such offense shall have been committed.

\section{U.S.C. $\$ 3286$. Extension of statute of limitation for certain terrorism offenses}

Notwithstanding section 3282, no person shall be prosecuted, tried, or punished for any offense involving a violation of section 32 (aircraft destruction), section 36 (airport violence), section 112 (assaults upon diplomats), section 351 (crimes against Congressmen or Cabinet officers), section 1116 (crimes against diplomats), section 1203 (hostage taking), section 1361 (willful injury to government property), section 1751 (crimes against the President), section 2280 (maritime violence), section 2281 (maritime platform violence), section 2331 (terrorist acts abroad against United States nationals), section 2339 (use of weapons of mass destruction), or section 2340A (torture) of this title or section 46502, 46504, 46505, or 46506 of title 49 , unless the indictment is found or the information is instituted within 8 years after the offense was committed.

\section{J. ARSON}

\section{U.S.C. § 7. Special maritime and territorial jurisdiction of the United States defined}

The term "special maritime and territorial jurisdiction of the United States", as used in this title, includes:

(1) The high seas, any other waters within the admiralty and maritime jurisdiction of the United States and out of the jurisdiction of any particular State, and any vessel belonging in whole or in part to the United States or any citizen thereof, or to any corporation created by or under the laws of the United States, or of any State, Territory, District, or possession thereof, when such vessel is within the admiralty and maritime jurisdiction of the United States and out of the jurisdiction of any particular State.

(2) Any vessel registered, licensed, or enrolled under the laws of the United States, and being on a voyage upon the waters of any of the Great Lakes, or any of the waters 
connecting them, or upon the Saint Lawrence River where the same constitutes the International Boundary Line.

(3) Any lands reserved or acquired for the use of the United States, and under the exclusive or concurrent jurisdiction thereof, or any place purchased or otherwise acquired by the United States by consent of the legislature of the State in which the same shall be, for the erection of a fort, magazine, arsenal, dockyard, or other needful building.

(4) Any island, rock, or key containing deposits of guano, which may, at the discretion of the President, be considered as appertaining to the United States.

(5) Any aircraft belonging in whole or in part to the United States, or any citizen thereof, or to any corporation created by or under the laws of the United States, or any State, Territory, district, or possession thereof, while such aircraft is in flight over the high seas, or over any other waters within the admiralty and maritime jurisdiction of the United States and out of the jurisdiction of any particular State.

(6) Any vehicle used or designed for flight or navigation in space and on the registry of the United States pursuant to the Treaty on Principles Governing the Activities of States in the Exploration and Use of Outer Space, Including the Moon and Other Celestial Bodies and the Convention on Registration of Objects Launched into Outer Space, while that vehicle is in flight, which is from the moment when all external doors are closed on Earth following embarkation until the moment when one such door is opened on Earth for disembarkation or in the case of a forced landing, until the competent authorities take over the responsibility for the vehicle and for persons and property aboard.

(7) Any place outside the jurisdiction of any nation with respect to an offense by or against a national of the United States.

(8) To the extent permitted by international law, any foreign vessel during a voyage having a scheduled departure from or arrival in the United States with respect to an offense committed by or against a national of the United States.

\section{U.S.C. § 81. Arson within special maritime and territorial jurisdiction}

Whoever, within the special maritime and territorial jurisdiction of the United States, willfully and maliciously sets fire to or burns, or attempts to set fire to or burn any building, structure or vessel, any machinery or building materials or supplies, military or naval stores, munitions of war, or any structural aids or appliances for navigation or shipping, shall be fined under this title or imprisoned not more than five years, or both.

If the building be a dwelling or if the life of any person be placed in jeopardy, he shall be fined under this title or imprisoned not more than twenty years, or both. 


\section{K. OBSCENITY}

18 U.S.C. \& 1460. Possession with intent to sell, and sale, of obscene matter on Federal property

(a) Whoever, either--

(1) in the special maritime and territorial jurisdiction of the UnitedStates, or on any land or building owned by, leased to, or otherwise used by or under the control of the Government of the United States; or

(2) in the Indian country as defined in section 1151 of this title,

knowingly sells or possesses with intent to sell an obscene visual depiction shall be punished by a fine in accordance with the provisions of this title or imprisoned for not more than 2 years, or both.

(b) For the purposes of this section, the term "visual depiction" includes undeveloped film and videotape but does not include mere words.

\section{U.S.C. \$ 1466. Engaging in the business of selling or transferring obscene matter}

(a) Whoever is engaged in the business of selling or transferring obscene matter, who knowingly receives or possesses with intent to distribute any obscene book, magazine, picture, paper, film, videotape, or phonograph or other audio recording, which has been shipped or transported in interstate or foreign commerce, shall be punished by imprisonment for not more than 5 years or by a fine under this title, or both.

(b) As used in this section, the term "engaged in the business" means that the person who sells or transfers or offers to sell or transfer obscene matter devotes time, attention, or labor to such activities, as a regular course of trade or business, with the objective of earning a profit, although it is not necessary that the person make a profit or that the selling or transferring or offering to sell or transfer such material be the person's sole or principal business or source of income. The offering for sale of or to transfer, at one time, two or more copies of any obscene publication, or two or more of any obscene article, or a combined total of five or more such publications and articles, shall create a rebuttable presumption that the person so offering them is "engaged in the business" as defined in this subsection.

\section{U.S.C. $\$ 1467$. Criminal forfeiture}

(a) Property subject to criminal forfeiture. A person who is convicted of an offense involving obscene material under this chapter [18 U.S.C. $\$ 1460$ et seq.] shall forfeit to the United States such person's interest in-- 
(1) any obscene material produced, transported, mailed, shipped, or received in violation of this chapter [18 U.S.C. $\$ 1460$ et seq.];

(2) any property, real or personal, constituting or traceable to gross profits or other proceeds obtained from such offense; and

(3) any property, real or personal, used or intended to be used to commit or to promote the commission of such offense, if the court in its discretion so determines, taking into consideration the nature, scope, and proportionality of the use of the property in the offense.

(b) Third party transfers. All right, title, and interest in property described in subsection (a) of this section vests in the United States upon the commission of the act giving rise to forfeiture under this section. Any such property that is subsequently transferred to a person other than the defendant may be the subject of a special verdict of forfeiture and thereafter shall be ordered forfeited to the United States, unless the transferee establishes in a hearing pursuant to subsection $(\mathrm{m})$ of this section that he is a bonafidepurchaser for value of such property who at the time of purchase was reasonably without cause to believe that the property was subject to forfeiture under this section.

(c) Protective orders.

(1) Upon application of the United States, the court may enter a restraining order or injunction, require the execution of a satisfactory performance bond, or take any other action to preserve the availability of property described in subsection (a) of this section for forfeiture under this section--

(A) upon the filing of an indictment or information charging a violation of this chapter [18 U.S.C. $\$ 1460$ et seq.] for which criminal forfeiture may beordered under this section and alleging that the property with respect to which the order is sought would, in the event of conviction, be subject to forfeiture under this section; or

(B) prior to the filing of such an indictment or information, if, after notice to persons appearing to have an interest in the property and opportunity for a hearing, the court determines that--

(i) there is a substantial probability that the United States will prevail on the issue of forfeiture and that failure to enter the order will result in theproperty being destroyed, removed from the jurisdiction of the court, or otherwise made unavailable for forfeiture; and

(ii) the need to preserve the availability of the property through the entry of the requested order outweighs the hardship on any party against whom the order is to be entered; 
except that an order entered under subparagraph $(B)$ shall be effective for not more than 90 days, unless extended by the court for good cause shown or unless an indictment or information described in subparagraph $(A)$ has been filed.

(2) A temporary restraining order under this subsection may be entered upon application of the United States without notice or opportunity for a hearing when an information or indictment has not yet been filed with respect to the property, if the United States demonstrates that there is probable cause to believe that the property with respect to which the order is sought would, in the event of conviction, be subject to forfeiture under this section and that provision of notice will jeopardize the availability of the property for forfeiture. Such a temporary order shall expire not more than 10 days after the date on which it is entered, unless extended for good cause shown or unless the party against whom it is entered consents to an extension for a longer period. A hearing requested concerning an order entered under this paragraph shall be held at the earliest possible time and prior to the expiration of the temporary order.

(3) The court may receive and consider, at a hearing held pursuant to this subsection, evidence and information that would be inadmissible under thefederal Rules of Evidence.

(d) Warrant of seizure. The Government may request the issuance of a warrant authorizing the seizure of property subject to forfeiture under this section in the same manner as provided for a search warrant. If the court determines that there is probable cause to believe that the property to be seized would, in the event of conviction, be subject to forfeiture and that an order under subsection (c) of this section may not be sufficient to assure the availability of the property for forfeiture, the court shall issue a warrant authorizing the seizure of such property.

(e) Order of forfeiture. The court shall order forfeiture of property referred to in subsection (a) if--

(1) the trier of fact determines, beyond a reasonable doubt, that such property is subject to forfeiture; and

(2) with respect to property referred to in subsection (a)(3), if the court exercises the court's discretion under that subsection.

(f) Execution. Upon entry of an order of forfeiture under this section, the court shall authorize the Attorney General to seize all property ordered forfeited upon such terms and conditions as the court shall deem proper. Following entry of an order declaring the property forfeited, the court may, upon application of the United States, enter such appropriate restraining orders or injunctions, require the execution of satisfactory performance bonds, appoint receivers, conservators, appraisers, accountants, or trustees, or take any other action to protect the interest of the United States in the property ordered forfeited. Any income accruing to or derived from property ordered forfeited under this section may be used to offset ordinary and necessary expenses to 
the property which are required by law, or which are necessary to protect the interests of the United States or third parties.

(g) Disposition of property. Following the seizure of property ordered forfeited under this section, the Attorney General shall destroy or retain for official use any property described in paragraph (1) of subsection (a) and shall direct the disposition of any property described in paragraph (2) or (3) of subsection (a) by sale or any other commercially feasible means, making due provision for the rights of any innocent persons. Any property right or interest not exercisable by, or transferable for value to, the United States shall expire and shall not revert to the defendant, nor shall the defendant or any person acting in concert with him or on his behalf be eligible to purchase forfeited property at any sale held by the United States. Upon application of a person, other than the defendant or person acting in concert with him or on his behalf, the court may restrain or stay the sale or disposition of the property pending the conclusion of any appeal of the criminal case giving rise to the forfeiture, if the applicant demonstrates that proceeding with the sale or disposition of the property will result in irreparable injury, harm, or loss to him.

(h) Authority of Attorney General. With respect to property ordered forfeited under this section, the Attorney General is authorized to--

(1) grant petitions for mitigation or remission of forfeiture, restore forfeited property to victims of a violation of this chapter [18 U.S.C. $\S \S 1460$ et seq.], or take any other action to protect the rights of innocent persons which is in the interest of justice and which is not inconsistent with the provisions of this section;

(2) comprise claims arising under this section;

(3) award compensation to persons providing information resulting in a forfeiture under this section;

(4) direct the disposition by the United States, under section 616 of the Tariff Act of 1930 [19 USCS $\$ 1616 a$ ], of all property ordered forfeited under this section by public sale or any other commercially feasible means, making due provision for the rights of innocent persons; and

(5) take appropriate measures necessary to safeguard and maintain property ordered forfeited under this section pending its disposition.

(i) Bar on intervention. Except as provided in subsection (1) of this section, no party claiming an interest in property subject to forfeiture under this section may--

(1) intervene in a trial or appeal of a criminal case involving the forfeiture of such property under this section; or 
(2) commence an action at law or equity against the United States concerningthe validity of his alleged interest in the property subsequent to the filing of an indictment or information alleging that the property is subject to forfeiture under this section.

(j) Jurisdiction to enter orders. The district courts of the United States shall have jurisdiction to enter orders as provided in this section without regard to the location of any property which may be subject to forfeiture under this section or which has been ordered forfeited under this section.

(k) Depositions. In order to facilitate the identification and location of property declared forfeited and to facilitate the disposition of petitions for remission or mitigation of forfeiture, after the entry of an order declaring property forfeited to the United States, the court may, upon application of the United States, order that the testimony of any witness relating to the property forfeited be taken by deposition and that any designated book, paper, document, record, recording, or other material not privileged be produced at the same time and place, in the same manner as provided for the taking of depositions under Rule 15 of the Federal Rules of Criminal Procedure.

(I) Third party interests.

(1) Following the entry of an order of forfeiture under this section, the United States shall publish notice of the order and of its intent to dispose of the property in such manner as the Attorney General may direct. The Government may also, to the extent practicable, provide direct written notice to any person known to have alleged an interest in the property that is the subject of the order of forfeiture as a substitute for published notice as to those persons so notified.

(2) Any person, other than the defendant, asserting a legal interest in property which has been ordered forfeited to the United States pursuant to this section may, within 30 days of the final publication of notice or his receipt of notice under paragraph (1), whichever is earlier, petition the court for a hearing to adjudicate the validity of his alleged interest in the property. The hearing shall be held before the court alone, without a jury.

(3) The petition shall be signed by the petitioner under penalty of perjury and shall set forth the nature and extent of the petitioner's right, title, or interest in the property, the time and circumstances of the petitioner's acquisition of the right, title, or interest in the property, any additional facts supporting the petitioner's claim, and the relief sought.

(4) The hearing on the petition shall, to the extent practicable and consistent with the interests of justice, be held within $\mathbf{3 0}$ days of the filing of the petition. The court may consolidate the hearing on the petition with a hearing on any other petition filed by a person other than the defendant under this subsection.

(5) At the hearing, the petitioner may testify and present evidence and witnesses on his own behalf, and cross-examine witnesses who appear at the hearing. The United States may present evidence and witnesses in rebuttal and in defense of its claim to 
the property and cross-examine witnesses who appear at the hearing. In addition to testimony and evidence presented at the hearing, the court shall consider the relevant portions of the record of the criminal case which resulted in the order of forfeiture.

(6) If, after the hearing, the court determines that the petitioner has established by a preponderance of the evidence that--

(A) the petitioner has a legal right, title, or interest in the property, and such right, title, or interest renders the order of forfeiture invalid in whole or in part because the right, title, or interest was vested in the petitioner rather than the defendant or was superior to any right, title, or interest of the defendant at the time of the commission of the acts which gave rise to the forfeiture of the property under this section; or

(B) the petitioner is a bonafide purchaser for value of the right, title, or interest in the property and was at the time of purchase reasonably without cause to believe that the property was subject to forfeiture under this section;

the court shall amend the order of forfeiture in accordance with its determination.

(7) Following the court's disposition of all petitions filed under this subsection, or if no such petitions are filed following the expiration of the period provided in paragraph (2) for the filing of such petitions, the United States shall have clear title to property that is the subject of the order of forfeiture and may warrant good title to any subsequent purchaser or transferee.

(m) Construction. This section shall be liberally construed to effectuate its remedial purposes.

(n) Substitute assets. If any of the property described in subsection (a), as a result of any act or omission of the defendant--

(1) cannot be located upon the exercise of due diligence;

(2) has been transferred or sold to, or deposited with, a third party;

(3) has been placed beyond the jurisdiction of the court;

(4) has been substantially diminished in value; or

(5) has been commingled with other property which cannot be divided without difficulty; the court shall order the forfeiture of any other property of the defendant up to the value of any property described in paragraphs (1) through (5). 
$-78-$ 


\section{TITLE 50. INTERNAL SECURITY ACT OF THE UNITED STATES CODE}

50 U.S.C. \$ 47a. Information concerning illegal introduction, manufacture, acquisition or export of special nuclear material or atomic weapons or conspiracies relating thereto; reward

Any person who furnishes original information to the United States--

(a) leading to the finding or other acquisition by the United States of special nuclear material or an atomic weapon which has been introduced into the United States or manufactured or acquired therein contrary to the laws of the United States, or

(b) with respect to the introduction or attempted introduction into the United States or the manufacture or acquisition or attempted manufacture or acquisition of, or a conspiracy to introduce into the United States or to manufacture or acquire, special nuclear material or an atomic weapon contrary to the laws of the United States, or

(c) with respect to the export or attempted export, or a conspiracy to export, special nuclear material or an atomic weapon from the United States contrary to the laws of the United States,

shall be rewarded by the payment of an amount not to exceed $\$ 500,000$.

50 U.S.C. \$ 421. Protection of identities of certain United States undercover intelligence officers, agents, informants, and sources

(a) Whoever, having or having had authorized access to classified information that identifies a covert agent, intentionally discloses any information identifying such covert agent to any individual not authorized to receive classified information, knowing that the information disclosed so identifies such covert agent and that the United States is taking affirmative measures to conceal such covert agent's intelligence relationship to the United States, shall be fined not more than $\$ 50,000$ or imprisoned not more than ten years, or both.

(b) Whoever, as a result of having authorized access to classified information, learns the identity of a covert agent and intentionally discloses any information identifying such covert agent to any individual not authorized to receive classified information, knowing that the information disclosed so identifies such covert agent and that the United States is taking affirmative measures to conceal such covert agent's intelligence relationship to the United States, shall be fined not more than $\$ 25,000$ or imprisoned not more than five years, or both.

(c) Whoever, in the course of a pattern of activities intended to identify and expose covert agents and with reason to believe that such activities would impair or impede the foreign intelligence activities of the United States, discloses any information that identifies an individual as a covert agent to any individual not authorized to receive classified information, knowing that the information disclosed so identifies such 
individual and that the United States is taking affirmative measures to conceal such individual's classified intelligence relationship to the United States, shall be fined not more than $\$ 15,000$ or imprisoned not more than three years, or both.

\section{U.S.C. \$ 422. Defenses and exceptions}

(a) It is a defense to a prosecution under section 601 [50 U.S.C. $\$ 421$ ] that before the commission of the offense with which the defendant is charged, the United States had publicly acknowledged or revealed the intelligence relationship to the United States of the individual the disclosure of whose intelligence relationship to the United States is the basis for the prosecution.

(b) (1) Subject to paragraph (2), no person other than a person committing an offense under section 601 shall be subject to prosecution under such section by virtue of section 2 or 4 of title 18, United States Code [18 U.S.C. § $\$ 2,4$ ], or shall be subject to prosecution for conspiracy to commit an offense under such section.

(2) Paragraph (1) shall not apply (A) in the case of a person who acted in the course of a pattern of activities intended to identify and expose covert agents and with reason to believe that such activities would impair or impede the foreign intelligence activities of the United States, or (B) in the case of a person who has authorized access to classified information.

(c) It shall not be an offense under section 601 [50 U.S.C. § 421] to transmit information described in such section directly to the Select Committee on intelligence of the Senate or to the Permanent Select Committee on Intelligence of the House of Representatives.

(d) It shall not be an offense under section 601 [50 U.S.C. \$ 421] for an individual to disclose information that solely indentifies himself as a covert agent.

50 U.S.C. § 423. Report

(a) The President, after receiving information from the Director of Central Intelligence, shall submit to the Select Committee on Intelligence of the Senate and the Permanent Select Committee on Intelligence of the House of Representatives an annual report on measures to protect the identities of covert agents, and on any other matter relevant to the protection of the identities of covert agents.

(b) The report described in subsection (a) shall be exempt from any requirement for publication or disclosure. The first such report shall be submitted no later than February 1, 1983. 


\section{U.S.C. $\$ 424$. Extraterritorial jurisdiction}

There is jurisdiction over an offense under section 601 [50 U.S.C. $§ 421$ ] committed outside the United States if the individual committing the offense is a citizen of the United States or an alien lawfully admitted to the United States for permanent residence (as defined in section $101(a)(20)$ of the Immigration and Nationality Act) [8 U.S.C. § 1101 (a)(20)].

\section{U.S.C. \$ 425. Providing information to Congress}

Nothing in this title [50 U.S.C. $\S \S 421$ et seq.] may be construed as authority to withhold information from the Congress or from a committee of either House of Congress.

\section{U.S.C. § 426. Definitions}

For the purposes of this title [50 U.S.C. $\S \S 421$ et seq.]:

(1) The term "classified information" means information or material designated and clearly marked or clearly represented, pursuant to the provisions of a statute or Executive order (or a regulation or order issued pursuant to a statute or Executive order), as requiring a specific degree of protection against unauthorized disclosure for reasons of national security.

(2) The term "authorized", when used with respect to access to classified information, means having authority, right, or permission pursuant to the provisions of a statute, Executive order, directive of the head of any department or agency engaged in foreign intelligence or counterintelligence activites, order of any United States court, or provisions of any Rule of the House of Representatives or resolution of the Senate which assigns responsibility within the respective House of Congress for the oversight of intelligence activities.

(3) The term "disclose" means to communicate, provide, impart, transmit, transfer, convey, publish, or otherwise make available.

(4) The term "covert agent" means--

(A) an officer or employee of an intelligence agency or a member of the Armed Forces assigned to duty with an intelligence agency--

(i) whose identity as such an officer, employee, or member is classified information, and

(ii) who is serving outside the United States or has within the last five years served outside the United States; or

(B) a United States citizen whose intelligence relationship to the United States is classified information, and-- 
(i) who resides and acts outside the United States as an agent of, or informant or source of operational assistance to, an intelligence agency, or

(ii) who is at the time of the disclosure acting as an agent of, or informant to, the foreign counterintelligence or foreign counterterrorism components of the Federal Bureau of Investigation; or

(C) an individual, other than a United States citizen, whose past or present intelligence relationship to the United States is classified information and who is a present or former agent of, or a present or former informant or source of operational assistance to, an intelligence agency.

(5) The term "intelligence agency" means the Central Intelligence Agency, a foreign intelligence component of the Department of Defense, or the foreign counterintelligence or foreign counterterrorism components of the Federal Bureau of Investigation.

(6) The term "informant" means any individual who furnishes information to an intelligence agency in the course of a confidential relationship protecting the identity of such individual from public disclosure.

(7) The terms "officer" and "employee" have the meanings given such terms by section 2104 and 2105, respectively, of title 5, United States Code [5 U.S.C. §§ 2104, 2105].

(8) The term "Armed Forces" means the Army, Navy, Air Force, Marine Corps, and Coast Guard.

(9) The term "United States", when used in a geographic sense, means all areas under the territorial sovereignty of the United States and the Trust Territory of the Pacific Islands.

(10) The term "pattern of activities" requires a series of acts with a common purpose or objective.

50 U.S.C. $\$ 783$. Offenses

(a) Communication of classified information by Government officer or employee. It shall be unlawful for any officer or employee of the United States or of any department or agency thereof, or of any corporation the stock of which is owned in whole or in major part by the United States or any department or agency thereof, to communicate in any manner or by any means, to any other person whom such officer or employee knows or has reason to believe to be an agent or representative of any foreign government, any information of a kind which shall have been classified by the President (or by the head of any such department, agency, or corporation with the approval of the President) as affecting the security of the United States, knowing or having reason to know that such information has been so classified, unless such officer or employee 
shall have been specifically authorized by the President, or by the head of the department, agency, or corporation by which this officer or employee is employed, to make such disclosure of such information.

(b) Receipt of, or attempt to receive, by foreign agent or member of Communist organization, classified information. It shall be unlawful for any agent or representative of any foreign government knowingly to obtain or receive, or attempt to obtain or receive, directly or indirectly, from any officer or employee of the United States or of any department or agency thereof or of any corporation the stock of which is owned in whole or in major part by the United States or any department or agency thereof, any information of a kind which shall have been classified by the President (or by the head of any such department, agency, or corporation with the approval of the President) as affecting the security of the United States, unless special authorization for such communication shall first have been obtained from the head of the department, agency, or corporation having custody of or control over such information.

(c) Penalties for violation. Any person who violates any provision of this section shall, upon conviction thereof, be punished by a fine of not more than $\$ 10,000$, or imprisonment for not more than ten years, or by both such fine and such imprisonment, and shall, moreover, be thereafter ineligible to hold any office, or place of honor, profit, or trust created by the Constitution or laws of the United States.

(d) Limitations period. Any person may be prosecuted, tried, and punished for any violation of this section at any time within ten years after the commission of such offense, notwithstanding the provisions of any other statute of limitations: Provided, That if at the time of the commission of the offense such person is an officer or employee of the United States or of any department or agency thereof, or of any corporation the stock of which is owned in whole or in major part by the United States or any department or agency thereof, such person may be prosecuted, tried, and punished for any violation of this section at any time within ten years after such person has ceased to be employed as such officer or employee.

(e) [Redesignated]

(f) [Repealed]

50 U.S.C. $\$ 784$. [Repealed]

50 U.S.C. § 797. Security regulations and orders; penalty for violation

(a) Whoever willfully shall violate any such regulation or order as, pursuant to lawful authority, shall be or has been promulgated or approved by the Secretary of Defense, or by any military commander designated by the Secretary of Defense, or by the Director of the National Advisory Committee for Aeronautics, for the protection or security of military or naval aircraft, airports, airport facilities, vessels, harbors, ports, piers, waterfront facilities, bases, forts, posts, laboratories, stations, vehicles, equipment, explosives, or other property or places subject to the jurisdiction, administration, or in the custody of the Department of Defense, and Department or 
agency of which said Department consists, or any officer or employee of said Department or agency, or of the National Advisory Committee for Aeronautics or any officer or employee thereof, relating to fire hazards, fire protection, lighting, machinery, guard service, disrepair, disuse or other unsatisfactory conditions thereon, or the ingress thereto or egress or removal of persons therefrom, or otherwise providing for safeguarding the same against destruction, loss, or injury by accident or by enemy action, sabotage or other subversive actions, shall be guilty of a misdemeanor and upon conviction thereof shall be liable to a fine of not to exceed $\$ 5,000$ or to imprisonment for not more than one year, or both.

(b) Every such regulation or order shall be posted in conspicuous and appropriate places. 


\section{TITLE 41 -- CODE OF FEDERAL REGULATIONS, CHAPTER 101 FEDERAL PROPERTY MANAGEMENT REGULATIONS (SELECTED PARTS ONLY)}

\section{CFR § 101-20.000. Scope of part}

The regulations in this part prescribe policies and procedures for the management, operation, protection, and maintenance of Government-owned and-leased buildings and grounds under the assignment responsibility of GSA.

\section{CFR $\S$ 101-20.002. Basic policy}

It is the responsibility of GSA to provide or otherwise arrange for all services required to house occupant agencies. GSA shall provide fully service space equivalent to that furnished in commercial practice.

\section{CFR § 101-20.003. Definitions}

(e) Crime prevention assessments are formal, on-site reviews which consist of a detailed survey, review, and analysis of an occupant agency's vulnerability to criminal activity. In addition to the normal process of a physical security survey, it involves an intensive review of an occupant's and/or building's operation and administrative procedures. It is designed to identify specific weaknesses and to recommend cost-effective, positive steps to Federal managers in dealing with criminal threats and occurrences.

(f) Cultural activities include, but are not limited to, films dramatics dances, and musical presentations, and fine art exhibits, whether or not these activities are intended to make a profit.

(g) The Designated Official is the highest ranking official of the primary occupant agency of a Federal facility; or, alternatively, a designee selected by mutual agreement of occupant agency officials.

(h) Educational activities mean activities such as (but not limited to) the operation of schools, libraries, day care centers, laboratories, and lecture or demonstration facilities.

(i) The term emergency includes bombings and bomb threats, civil disturbances, fires, explosions, electrical failures, loss of water pressure, chemical and gas leaks, medical emergencies, hurricanes, tornadoes, floods, and earthquakes. The term does not apply to civil defense matters such as potential or actual enemy attacks. Note: Civil defense emergencies are addressed by the Federal Emergency Management Agency.

Comment. Only certain definitions are provided here. 


\section{CFR § 101-20.103-1 Standard protection.}

For properties under its custody and control, GSA will provide standard protection services by:

(a) Responding to criminal occurrences, incidents, and lifethreatening events through the use of Federal Protective Officers and local law enforcement officers where a response agreement is in effect.

(b) Installing and maintaining perimeter security devices and systems if they are monitored to provide timely response by authorized personnel;

(c) Implementing crime prevention activities, including tenant awareness programs;

(d) Investigating crimes and violations of Federal statutes, recording and evaluating reports of criminal incidents, and referring findings and evidence to appropriate enforcement agencies;

(e) Entering into cooperative agreements with local law enforcement agencies;

(f) Performing physical security surveys and providing security advisory services; or

(g) Coordinating a comprehensive Occupant Emergency Program.

(h) Periodically evaluating the effectiveness of protection services by in-depth inspections of procedures and records.

\section{CFR § 101-20.103-2. Special protection}

The degree of protection beyond standard levels required by the nature of an agency's activities or by unusual public reaction to an agency's programs will be determined jointly by GSA and the occupant agency. Special protection will be provided on a reimbursable basis. The level of special protection will be determined on a facility-by-facility basis, after the conducting of appropriate security surveys and crime prevention assessments. In such determinations, GSA and occupant agencies will consider:

(a) The characteristics of the facility, including size, configuration, exterior lighting, and presence of physical barriers;

(b) The location of the facility and the history of criminal or disruptive incidents in the surrounding neighborhoods; and

(c) The reimbursable funding and resources available to GSA for provision of protective service.

(d) Tenant agency's mission. 
41 CFR $\$$ 101-20.103-3. Responsibilities of occupant agencies

Occupants of facilities under the custody and control of GSA shall:

(a) Cooperate to the fullest extent with all pertinent facility procedures and regulations;

(b) Promptly report all crimes and suspicious circumstances occurring on GSA-controlled property to the regional Law Enforcement Branch and other designated law enforcement agencies and then through internal agency channels;

(c) Provide training to employees regarding protection and responses to emergency situations; and

(d) Make recommendations for improving the effectiveness of protection in Federal facilities.

\section{CFR $\$$ 101-20.3. -- CONDUCT ON FEDERAL PROPERTY}

\section{CFR § 101-20.300. Applicability}

These rules and regulations apply to all property under the charge and control of the General Services Adminstration and to all persons entering in or on such property. Each occupant agency shall be responsible for the observance of these rules and regulations.

\section{CFR § 101-20.301. Inspection}

Packages, briefcases, and other containers in the immediate possession of visitors, employees, or other persons arriving on, working at, visiting, or departing from Federal property, are subject to inspection. A full search of a person and any vehicle driven or occupied by the person may accompany an arrest.

\section{CFR $\$$ 101-20.302. Admission to property}

Property shall be closed to the public during other than normal working hours. The closing of property will not apply to that space in those instances where the Government has approved the after-normal-working-hours use of buildings or portions thereof for activities authorized by subpart 101-20.4. During normal working hours, property shall be closed to the public only when situations require this action to ensure the orderly conduct of Government business. The decision to close the property shall be made by the designated official under the Occupant Emergency program after consultation with the buildings manager and the ranking representative of the Law Enforcement Branch responsible for protection of the facility or the area. The designated official is defined in $\$ 101-20.003(\mathrm{~g})$ as the highest ranking official of the primary occupant agency, or the alternate highest ranking offical or designee selected by mutual agreement by other occupant agency officials. When property, or a portion thereof, is closed to the public, admission to this property, or a portion, will be restricted to authorized persons who shall register upon entry to the property and shall, when requested, display Government or other identifying credentials to the Federal Protective Officers or other 
authorized individuals when entering, leaving, or while on the property. Failure to comply with any of the applicable provisions is a violation of these regulations.

\section{CFR § 101-20.303. Preservation of property}

The improper disposal of rubbish on property; the willful destruction of or damage to property; the theft of property; the creation of any hazard on property to persons or things; the throwing of articles of any kind from or at a building or the climbing upon statues, fountains, or any part of the building, is prohibited.

\section{CFR § 101-20.304. Conformity with signs and directions}

Persons in and on property shall at all times comply with official signs of a prohibitory, regulatory, or directory nature and with the lawful direction of Federal Protective Officers and other authorized individuals.

\section{CFR § 101-20.305. Disturbances}

Any loitering, disorderly conduct, or other conduct on property which creates loud or unusual noise or a nuisance; which unreasonably obstructs the usual use of entrances, foyers, lobbies, corridors, offices, elevators, stairways, or parking lots; which otherwise impedes or disrupts the performance of official duties by Government employees; or which prevents the general public from obtaining the administrative services provided on the property in a timely manner, is prohibited.

\section{CFR § 101-20.306. Gambling}

Participating in games for money or other personal property or the operating of gambling devices, the conduct of a lottery or pool, or the selling or purchasing of numbers tickets, in or on property is prohibited. This prohibition shall not apply to the vending or exchange of chances by licensed blind operators of vending facilities for any lottery set forth in a State law and authorized by section 2(a)(5) of the Randolph-Sheppard Act (20 U.S.C. 107, et seq.)

\section{CFR § 101-20.307. Alcoholic beverages and narcotics}

Operations of a motor vehicle while on the property by a person under the influence of alcoholic beverages, narcotic drugs, hallucinogens, marijuana, barbiturates, or amphetamines is prohibited. Entering upon the property, or while on the property, under the influence of or using or possessing any narcotic drugs, hallucinogens, marijuana, barbiturates, or amphetamines is prohibited. The prohibition shall not apply in cases where the drug is being used as prescribed for a patient by a licensed physician. Entering upon the property, or being on the property, under the influence of alcoholic beverages is prohibited. The use of alcoholic beverages on property is prohibited except, upon occasions and on property upon which the head of the responsible agency or his or her designee has for appropriate official uses granted an exemption in writing. The head of the responsible agency or his or her designee shall provide a copy of all exemptions granted to the buildings manager and the Chief, Law Enforcement Branch, or other authorized officials, reponsible for the security of the property. 


\section{CFR § 101-20.308. Soliciting, vending, and debt collection}

Soliciting alms, commercial or political soliciting, and vending of all kinds, displaying or distributing commercial advertising, or collecting private debts on GSA-controlled property is prohibited. This rule does not apply to:

(a) National or local drives for funds for welfare, health, or other purposes as authorized by 5 CFR, parts 110 and 950, Solicitation of Federal Civilian and Uniformed Services Personnel for Contributions to Private Voluntary Organizations issued by the U.S. Office of Personnel Management under Executive Order 12353 of March 23, 1982, as amended, and sponsored or approved by the occupant agencies;

(b) Concessions or personal notices posted by employees on authorized bulletin boards;

(c) Solicitation of labor organization membership or dues authorized by occupant agencies under the Civil Service Reform Act of 1978 (Pub. L. 95-454); and

(d) Lessee, or its agents and employees, with respect to space leased for commercial, cultural, educational, or recreational use under the Public Buildings Cooperative Use Act of 1976 (40 U.S.C. $490(a)(16)$ ).

NOTE: Public areas of GSA-controlled property may be used for other activities permitted in accordance with subpart 101-20.4.

\section{CFR § 101-20.309. Posting and distributing materials}

Posting or affixing materials, such as pamphlets, handbills, or flyers, on bulletin boards or elsewhere on GSA-controlled property is prohibited, except as authorized in $\S 101-20.308$ or when these displays are conducted as part of authorized Government activities. Distribution of materials, such as pamphlets, handbills, or flyers, is prohibited, except in the public areas of the property as defined in $\S 101-20.003(z)$, unless conducted as part of authorized Government activities. Any person or organization proposing to distribute materials in a public area under this section shall first obtain a permit from the building manager under subpart 101-20.4 and shall conduct distribution in accordance with the provisions of subpart 101-20.4. Failure to comply with those provisions is a violation of these regulations.

\section{CFR § 101-20.310. Photographs for news, advertising, or commercial purposes}

Photographs may be taken in space occupied by a tenant agency only with the consent of the occupying agency concerned. Except where security regulations apply or a Federal court order or rule prohibits it, photographs for news purposes may be taken in entrances, lobbies, foyers, corridors, or auditoriums when used for public meetings. Subject to the foregoing prohibitions, photographs for advertising and commercial purposes may be taken only with written permission of an authorized official of the agency occupying the space where the photographs are to be taken. 


\section{CFR § 101-20.311. Dogs and other animals}

Dogs and other animals, except seeing eye dogs, other guide dogs, and animals used to guide or assist handicapped persons, shall not be brought upon property for other than official purposes.

\section{CFR § 101-20.312. Vehicular and pedestrian traffic}

(a) Drivers of all vehicles entering or while on property shall drive in a careful and safe manner at all times and shall comply with the signals and directions of Federal protective officers or other authorized individuals and all posted traffic signs;

(b) The blocking of entrances, driveways, walks, loading platforms, or fire hydrants on property is prohibited; and

(c) Except in emergencies, parking on property is not allowed without a permit. Parking without authority, parking in unauthorized locations or in locations reserved for other persons, or parking contrary to the direction of posted signs is prohibited. Vehicles parked in violation, where warning signs are posted, shall be subject to removal at the owners' risk and expense. This paragraph may be supplemented from time to time with the approval of the Regional Administrator by the issuance and posting of such specific traffic directives as may be required, and when so issued and posted such directives shall have the same force and effect as if made a part thereof. Proof that a motor vehicle was parked in violation of these regulations or directives may be taken as prima facie evidence that the registered owner was responsible for the violation.

\section{CFR § 101-20.313. Explosives}

No person entering or while on property shall carry or possess explosives, or items intended to be used to fabricate an explosive or incendiary device, either openly or concealed, except for official purposes. (Weapons, see title 18, U.S. Code 930.)

\section{CFR § 101-20.314. Nondiscrimination}

There shall be no discrimination by segregation or otherwise against any person or persons because of race, creed, sex, color, or national origin in furnishing or by refusing to furnish to such person or persons the use of any facility of a public nature, including all services, privileges, accommodations, and activities provided thereby on the property.

\section{CFR § 101-20.315. Penalties and other laws}

Whoever shall be found guilty of violating any rule or regulations in this subpart 101-20.3 while on any property under the charge and control of the U.S. General Services Administration is subject to a fine of not more than $\$ 50$ or imprisonment of not more than 30 days, or both (See title 40 U.S. Code 318c.) Nothing in these rules and regulations shall be construed to abrogate any other Federal laws or regulations or any State and local laws and 
regulations applicable to any area in which the property is situated (section 205(c), 63 U.S. Statutes, 390; 40 U.S. Code 486(c)). 
